Prepared for the Federal Emergency Management Agency, Region 1

\title{
Scoping of Flood Hazard Mapping Needs for Coos County, New Hampshire
}

Open-File Report 2006-1200 


\section{Scoping of Flood Hazard Mapping Needs for Coos County, New Hampshire}

By Robert H. Flynn

In cooperation with the

Federal Emergency Management Agency, Region 1

Open-File Report 2006-1200

U.S. Department of the Interior

U.S. Geological Survey 


\title{
U.S. Department of the Interior DIRK KEMPTHORNE, Secretary
}

\author{
U.S. Geological Survey \\ P. Patrick Leahy, Acting Director
}

U.S. Geological Survey, Reston, Virginia: 2006

\author{
For more information about the USGS and its products: \\ Telephone: 1-888-ASK-USGS \\ World Wide Web: http://www.usgs.gov/ \\ Any use of trade, product, or firm names in this publication is for descriptive purposes only and does not imply \\ endorsement by the U.S. Government. \\ Although this report is in the public domain, permission must be secured from the individual copyright owners to \\ reproduce any copyrighted materials contained within this report.
}




\section{Acknowledgments}

The author thanks Debra Foster for her assistance in contacting towns in Coos County to obtain preliminary scoping needs information and for editing this report, Ann Marie Squillacci for her help in formatting the tables, and Tina Cotton for her help with the figures. 


\section{Contents}

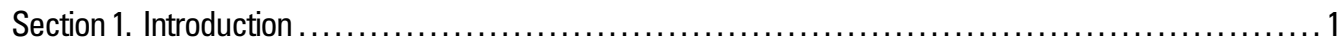

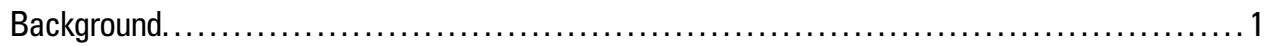

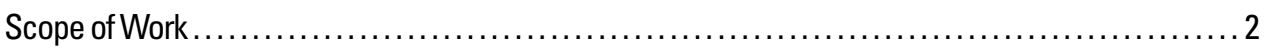

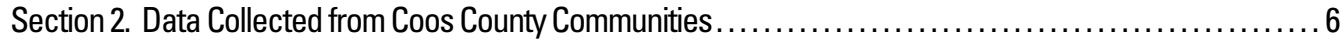

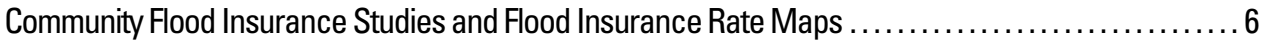

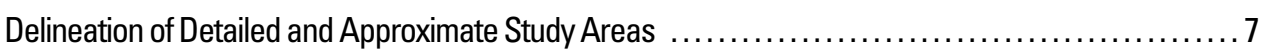

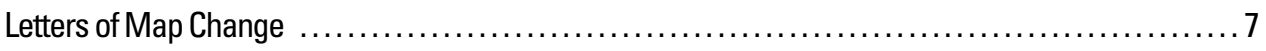

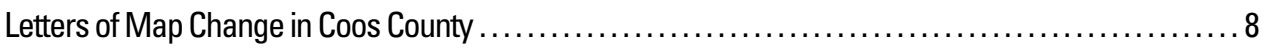

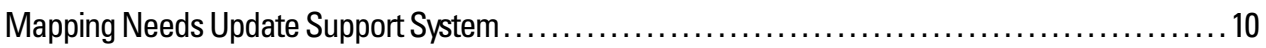

Mapping Needs in Coos County, New Hampshire .................................... 10

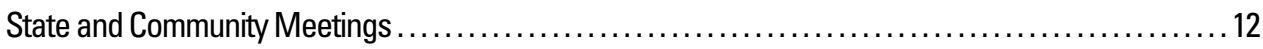

Meeting with New Hampshire Office of Emergency Management (NHOEM) and

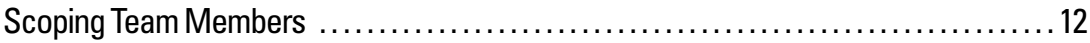

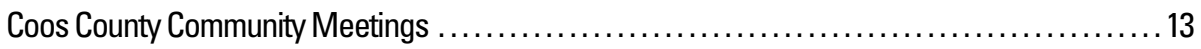

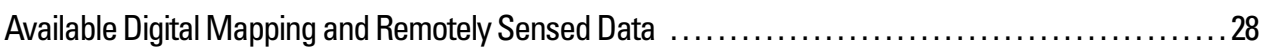

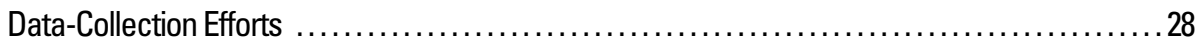

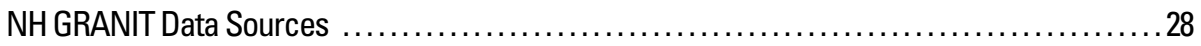

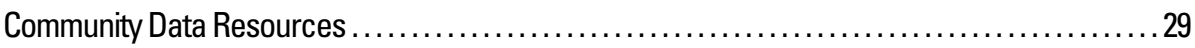

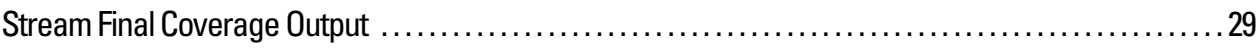

Section 3. Options for Future Mapping and Digital Terrain Model Preparation. . . . . . . . . . . . . . . . . . . . 31

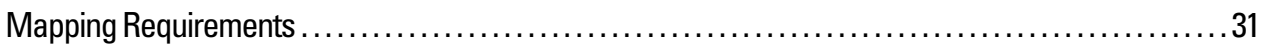

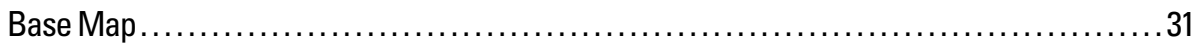

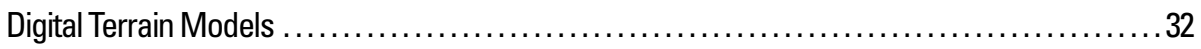

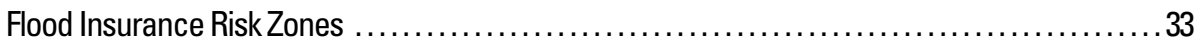

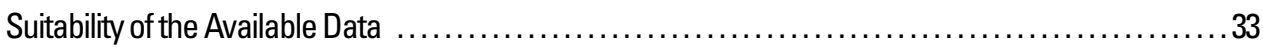

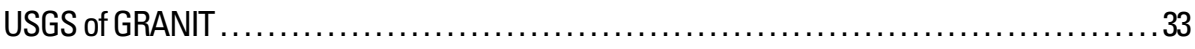

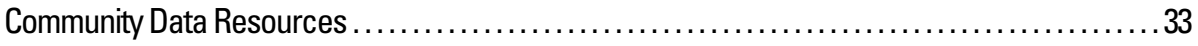

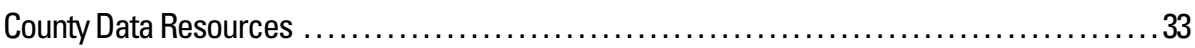

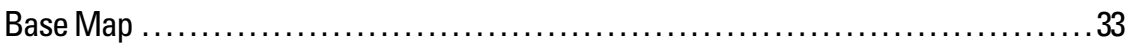

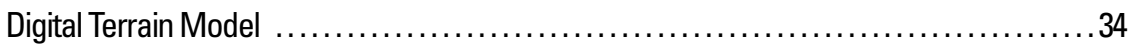

Flood Insurance Risk Zones ........................................... 34

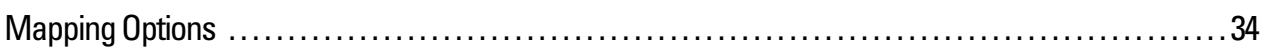

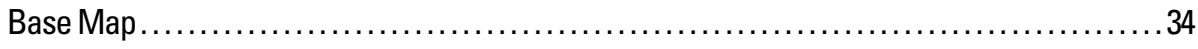

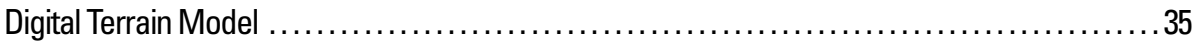

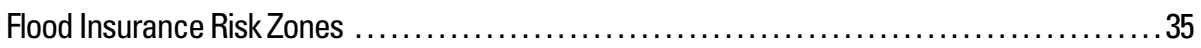

Section 4. Hydrologic and Hydraulic Restudy Needs and Prioritization ........................... 36

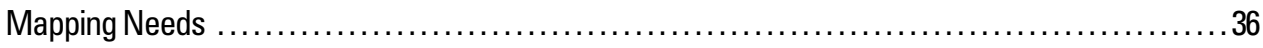

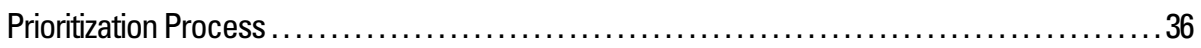

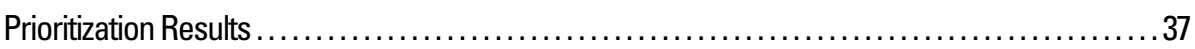

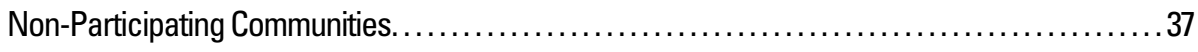

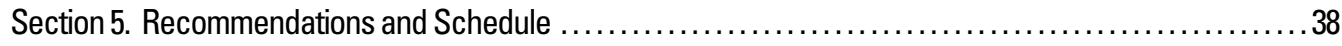

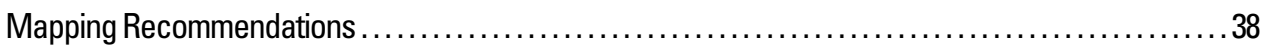

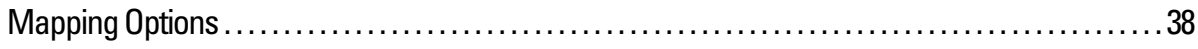




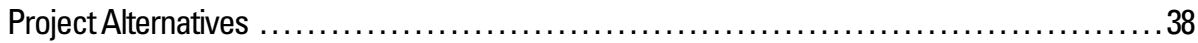

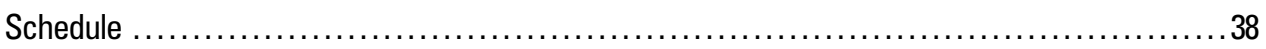

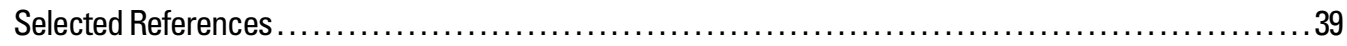

Appendixes:

Appendix A. Summary of Letters of Map Change (LOMC) Data in Coos County ....................... 41

Appendix B. Mapping Needs Update Support System (MNUSS) Needs Assessment Reports . . . . . . . . . 43

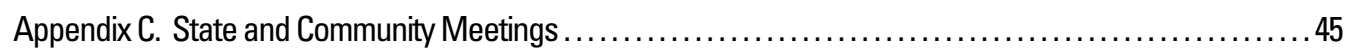

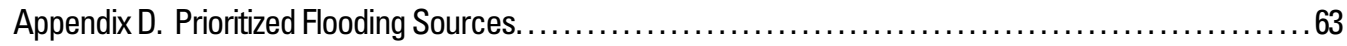

\section{Figures}

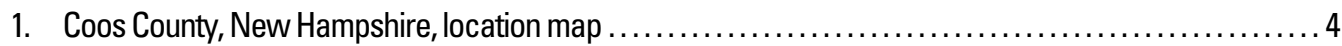

2. Coos County, New Hampshire, hydrography and FEMA Digital Flood Insurance Rate Map

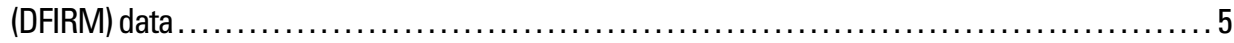

3. Letter of Map Change (LOMC) and community location map in Coos County, New Hampshire...........9

4. Coos County, New Hampshire, stream final coverage .................................. 30

\section{Tables}

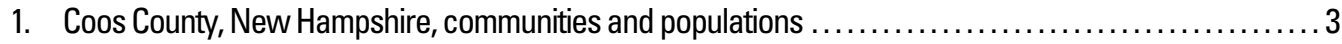

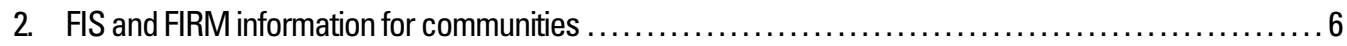

3. Summary of specific mapping needs in Coos County, New Hampshire .......................... 11

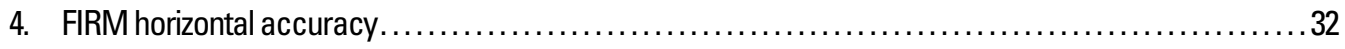

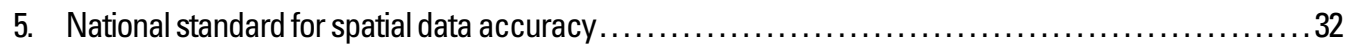

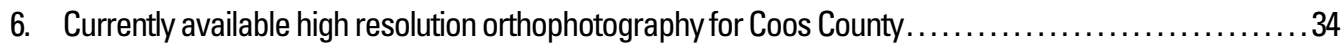

7. Estimate of costs to obtain Digital Terrain Model data (2-ft contours) ........................... 35

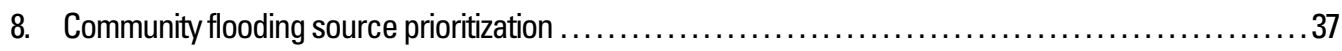


CONVERSION FACTORS AND ABBREVIATIONS

\begin{tabular}{|c|c|c|}
\hline Multiply & By & To obtain \\
\hline \multicolumn{3}{|c|}{ Length } \\
\hline inch (in.) & 25.4 & millimeter $(\mathrm{mm})$ \\
\hline foot $(\mathrm{ft})$ & 0.3048 & meter $(\mathrm{m})$ \\
\hline mile (mi) & 1.609 & kilometer $(\mathrm{km})$ \\
\hline \multicolumn{3}{|c|}{ Area } \\
\hline square foot $\left(\mathrm{ft}^{2}\right)$ & 0.09290 & square meter $\left(\mathrm{m}^{2}\right)$ \\
\hline square inch $\left(\mathrm{in}^{2}\right)$ & 6.452 & square centimeter $\left(\mathrm{cm}^{2}\right)$ \\
\hline square mile $\left(\mathrm{mi}^{2}\right)$ & 2.590 & square kilometer $\left(\mathrm{km}^{2}\right)$ \\
\hline \multicolumn{3}{|c|}{ Volume } \\
\hline cubic foot $\left(\mathrm{ft}^{3}\right)$ & 0.02832 & cubic meter $\left(\mathrm{m}^{3}\right)$ \\
\hline \multicolumn{3}{|c|}{ Slope } \\
\hline foot per mile (ft/mi) & 0.1894 & meter per kilometer $(\mathrm{m} / \mathrm{km})$ \\
\hline \multicolumn{3}{|c|}{ Velocity and Flow } \\
\hline foot per second (ft/s) & 0.3048 & meter per second $(\mathrm{m} / \mathrm{s})$ \\
\hline cubic foot per second $\left(\mathrm{ft}^{3} / \mathrm{s}\right)$ & 0.02832 & cubic meter per second $\left(\mathrm{m}^{3} / \mathrm{s}\right)$ \\
\hline
\end{tabular}

Horizontal coordinate information is referenced to the insert datum name (and abbreviation) here for instance, “North American Datum of 1983 (NAD 83)."

\section{OTHER ABBREVIATIONS USED IN REPORT}

$\begin{array}{ll}\text { APFO } & \text { Aerial Photography Field Office } \\ \text { BFE } & \text { Base Flood Elevation } \\ \text { CAC } & \text { Community Assistance Contact } \\ \text { CAV } & \text { Community Assistance Visit } \\ \text { cfs } & \text { cubic feet per second } \\ \text { CID } & \text { Community Identification } \\ \text { CIS } & \text { Community Information System } \\ \text { COTR } & \text { Contracting Officer's Technical Representative } \\ \text { CTP } & \text { Cooperating Technical Partner } \\ \text { DEM } & \text { Digital Elevation Model } \\ \text { DFIRM } & \text { Digital Flood Insurance Rate Map } \\ \text { DOQ } & \text { Digital Orthophoto Quadrangle } \\ \text { DOQQ } & \text { Digital Ortho Quarter Quadrangle } \\ \text { DTM } & \text { Digital Terrain Model } \\ \text { FBFM } & \text { Flood Boundary and Floodway Map } \\ \text { FEMA } & \text { Federal Emergency Management Agency } \\ \text { FHBM } & \text { Flood Hazard Boundary Map } \\ \text { FIRM } & \text { Flood Insurance Rate Map } \\ \text { FIS } & \text { Flood Insurance Study }\end{array}$




\begin{tabular}{|c|c|}
\hline GIS & Geographic Information System \\
\hline GRANIT & Geographically Referenced ANalysis and Information Transfer system \\
\hline GSP & Ground Sample Distance \\
\hline $\mathrm{H} \& \mathrm{H}$ & Hydrologic and Hydraulic \\
\hline LiDAR & Light Detection and Ranging \\
\hline LOMA & Letter of Map Amendment \\
\hline LOMC & Letters of Map Change \\
\hline LOMR & Letter of Map Revision \\
\hline LOMR-F & Letter of Map Revision based on Fill \\
\hline MNA & Mapping Needs Assessment \\
\hline MNUSS & Mapping Needs Update Support System \\
\hline MrSID & Multi-resolution Seamless Image Database \\
\hline NAIP & National Agriculture Imagery Program \\
\hline NDOP & National Digital Ortho Program \\
\hline NED & National Elevation Dataset \\
\hline NFIP & National Flood Insurance Program \\
\hline NHD & National Hydrography Dataset \\
\hline NHDOT & New Hampshire Department of Transportation \\
\hline NHOEM & New Hampshire Office of Emergency Management \\
\hline NHOEP & New Hampshire Office of Energy and Planning \\
\hline NSSDA & National Standard for Spatial Data Accuracy \\
\hline $\mathrm{RMC}$ & Regional Management Center \\
\hline SFHA & Special Flood Hazard Area \\
\hline TIN & Triangulated Irregular Network \\
\hline UNH & University of New Hampshire \\
\hline USACE & United States Army Corps of Engineers \\
\hline USDA & United States Department of Agriculture \\
\hline USEPA & United States Environmental Protection Agency \\
\hline USGS & United States Geological Survey \\
\hline UTM & Universal Transverse Mercator \\
\hline WISE & Watershed Information System \\
\hline
\end{tabular}




\title{
Scoping of Flood Hazard Mapping Needs for Coos County, New Hampshire
}

\author{
By Robert H. Flynn
}

\section{Section 1. Introduction}

This report was prepared by the U.S. Geological Survey (USGS) New Hampshire/Vermont Water Science Center for scoping of flood-hazard mapping needs for Coos County, New Hampshire, under Federal Emergency Management Agency (FEMA) Inter-Agency agreement Number HSFE01-05X-0018. This section of the report explains the objective of the task and the purpose of the reports.

\section{Background}

FEMA is embarking on a map modernization program nationwide to:

1. Gather and develop updated data for all flood prone areas in support of flood plain management.

2. Provide maps and data in a digital format for the improvement in the efficiency and precision of the mapping program.

3. Integrate FEMA's community and state partners into the mapping process.

One of the priorities for FEMA, Region 1, is to develop updated Digital Flood Insurance Rate Maps (DFIRMs) and Flood Insurance Studies (FIS) for Coos County, New Hampshire. The information provided in this report will be used to develop the scope for the first phase of a multiyear project that will ultimately result in the production of new DFIRMs and FIS for the communities and flooding sources in Coos County.

The average age of the FEMA flood plain maps in Coos County, New Hampshire is 20 years. Most of these studies were computed in the mid 1970s to the mid 1980s. However, in the ensuing 20-30 years, development has occurred in many of the watersheds, and the rivers and streams and their flood plains have changed with time. In addition, as development has occurred, the peak flooding has increased downstream of the development due to increased flows from impervious surfaces. Therefore, many of the older studies may not depict current conditions nor accurately estimate risk in terms of flood heights.

Coos County gained 544 residents between 2000 and 2005. This represents a growth of 1.6 percent compared to 6.0 percent for the state as a whole. Coos County ranks tenth (from highest to lowest) out of New Hampshire's 10 counties in terms of rate of population increase. Since 1990, Coos County has lost 1,173 residents (University of New Hampshire, 2005). 


\section{Scope of Work}

The following is the scope of work as defined in the FEMA/USGS Statement of Work:

Task 1: Collect data from a variety of sources including community surveys, other Federal and State Agencies, National Flood Insurance Program (NFIP) State Coordinators, Community Assistance Visits (CAVs) and FEMA archives. Lists of mapping needs will be obtained from the Mapping Needs Update Support System (MNUSS) database, community surveys, and CAVs, if available. FEMA archives will be inventoried for effective Flood Insurance Rate Maps (FIRM) panels, FIS reports, and other flood hazard data or existing study data. Best available base map information, topographic data, flood hazard data, and hydrologic and hydraulic $(\mathrm{H} \& \mathrm{H})$ data will be identified and obtained. FEMA Letters of Map Change (LOMC) areas will also be identified.

Task 2: Contact communities in Coos County to notify them that FEMA and the State have selected them for a map update, and that a project scope will be developed with their input. Topics to be reviewed with the communities include (1) Purpose of the Flood Map Project (for example, the update needs that have prompted the map update); (2) The community's mapping needs; (3) The community's available mapping, hydrologic, hydraulic, and flooding information; (4) Target schedule for completing the project; and (5) The community's engineering, planning, and geographic information system (GIS) capabilities. When requested by the community, or when needed to obtain information on mapping needs and available information, the USGS will schedule meetings with individual communities.

Based on the collected information from Task 1 and community contacts/meetings in Task 2, the USGS will develop a Draft Project Scope for the identified mapping needs of the communities in Coos County. The following items will be addressed in the Draft Project Scope: review of available information; determine if and how the currently effective FIS data can be used in new project; identify other data needed to complete the Project and its source; and the DFIRM format. The Draft Project Scope will establish priority levels for flooding sources to be analyzed and mapped, and estimate schedules for completion of the components of flood mapping.

The USGS is to supply the FEMA Contracting Officer's Technical Representative (COTR) with a report summarizing the following:

1. Available data and collected information on mapping needs.

2. Documentation of meetings and contacts.

3. Suitability of existing data and options for future mapping.

4. Restudy needs and priorities.

5. Recommended project scope and cost.

This report provides a summary of data-collection efforts conducted for this task, as well as information on available mapping/remote sensing data. The report includes recommendations for providing needed mapping/remote sensing data to accomplish the ultimate goal of producing new DFIRMs. It also provides options for accomplishing this goal within the context of FEMA's Cooperating Technical Partner (CTP) Program. The report begins the process of establishing restudy priorities in Coos County.

The communities of Coos County and their populations are listed in table 1, and the location of Coos County in New Hampshire is shown in figure 1. The Coos County Hydrography and FEMA DFIRM Data, county communities, rivers and streams and flood zones are shown in figure 2. 
Table 1. Coos County, New Hampshire, communities and populations.

\begin{tabular}{|c|c|c|c|}
\hline County/Town & $\begin{array}{c}\text { Year } 2000 \\
\text { population }\end{array}$ & $\begin{array}{l}\text { Land area } \\
\text { (square mile) }\end{array}$ & $\begin{array}{l}\text { Population per } \\
\text { square mile }\end{array}$ \\
\hline Coos County & 33,511 & 1,800 & 18.6 \\
\hline Atkinson and Gilmanton Academy Grant ${ }^{1}$ & 12 & 19.7 & 0.6 \\
\hline Beans Grant ${ }^{1}$ & 1 & 5.2 & 0.2 \\
\hline Beans Purchase $^{1}$ & 4 & 65.2 & 0.1 \\
\hline Berlin & 10,484 & 61.7 & 169.9 \\
\hline Cambridge $^{1}$ & 10 & 50.8 & 0.2 \\
\hline Carroll & 725 & 50.2 & 14.4 \\
\hline Chandlers Purchase ${ }^{1}$ & 1 & 2.1 & 0.5 \\
\hline Clarksville & 294 & 60.2 & 4.9 \\
\hline Colebrook & 2,377 & 41 & 58 \\
\hline Columbia & 789 & 60.8 & 13 \\
\hline Crawfords Purchase ${ }^{1}$ & 1 & 8.2 & 0.1 \\
\hline Cutts Grant ${ }^{1}$ & 1 & 11.4 & 0.1 \\
\hline Dalton & 921 & 27.5 & 33.5 \\
\hline Dixs Grant $^{1}$ & 1 & 20.2 & 0 \\
\hline Dixville & 75 & 48.9 & 1.5 \\
\hline Dummer & 312 & 47.8 & 6.5 \\
\hline Errol & 294 & 61 & 4.8 \\
\hline Ervings Location ${ }^{1}$ & 1 & 3.7 & 0.3 \\
\hline Gorham & 2,918 & 31.9 & 91.5 \\
\hline Greens Grant ${ }^{1}$ & 1 & 3.7 & 0.3 \\
\hline Hadleys Purchase ${ }^{1}$ & 1 & 7.4 & 0.1 \\
\hline Jefferson & 1,036 & 50.2 & 20.6 \\
\hline Kilkenny ${ }^{1}$ & 1 & 25.6 & 0 \\
\hline Lancaster & 3,388 & 50.1 & 67.6 \\
\hline Low and Burbanks Grant ${ }^{1}$ & 1 & 26.1 & 0 \\
\hline Martins Location ${ }^{1}$ & 1 & 3.8 & 0.3 \\
\hline Milan & 1,379 & 61.7 & 22.4 \\
\hline Millsfield ${ }^{1}$ & 22 & 45 & 0.5 \\
\hline Northumberland & 2,412 & 36.2 & 66.6 \\
\hline Odell $^{1}$ & 5 & 44.5 & 0.1 \\
\hline Pinkhams Grant ${ }^{1}$ & 1 & 3.8 & 0.3 \\
\hline Pittsburg & 863 & 282.3 & 3.1 \\
\hline Randolph & 343 & 47.1 & 7.3 \\
\hline Sargents Purchase ${ }^{1}$ & 1 & 25.9 & 0 \\
\hline Second College Grant ${ }^{1}$ & 1 & 41.6 & 0 \\
\hline Shelburne & 387 & 47.9 & 8.1 \\
\hline Stark & 510 & 59.1 & 8.6 \\
\hline Stewartstown & 1,003 & 46.4 & 21.6 \\
\hline Stratford & 931 & 79.8 & 11.7 \\
\hline Success ${ }^{1}$ & 2 & 58.8 & 0 \\
\hline Thompson and Meserves Purchase ${ }^{1}$ & 1 & 18.5 & 0.1 \\
\hline Wentworth Location ${ }^{1}$ & 43 & 18.8 & 0.1 \\
\hline Whitefield & 2,007 & 34.2 & 58.7 \\
\hline
\end{tabular}

\footnotetext{
${ }^{1}$ Unincorporated towns.
} 


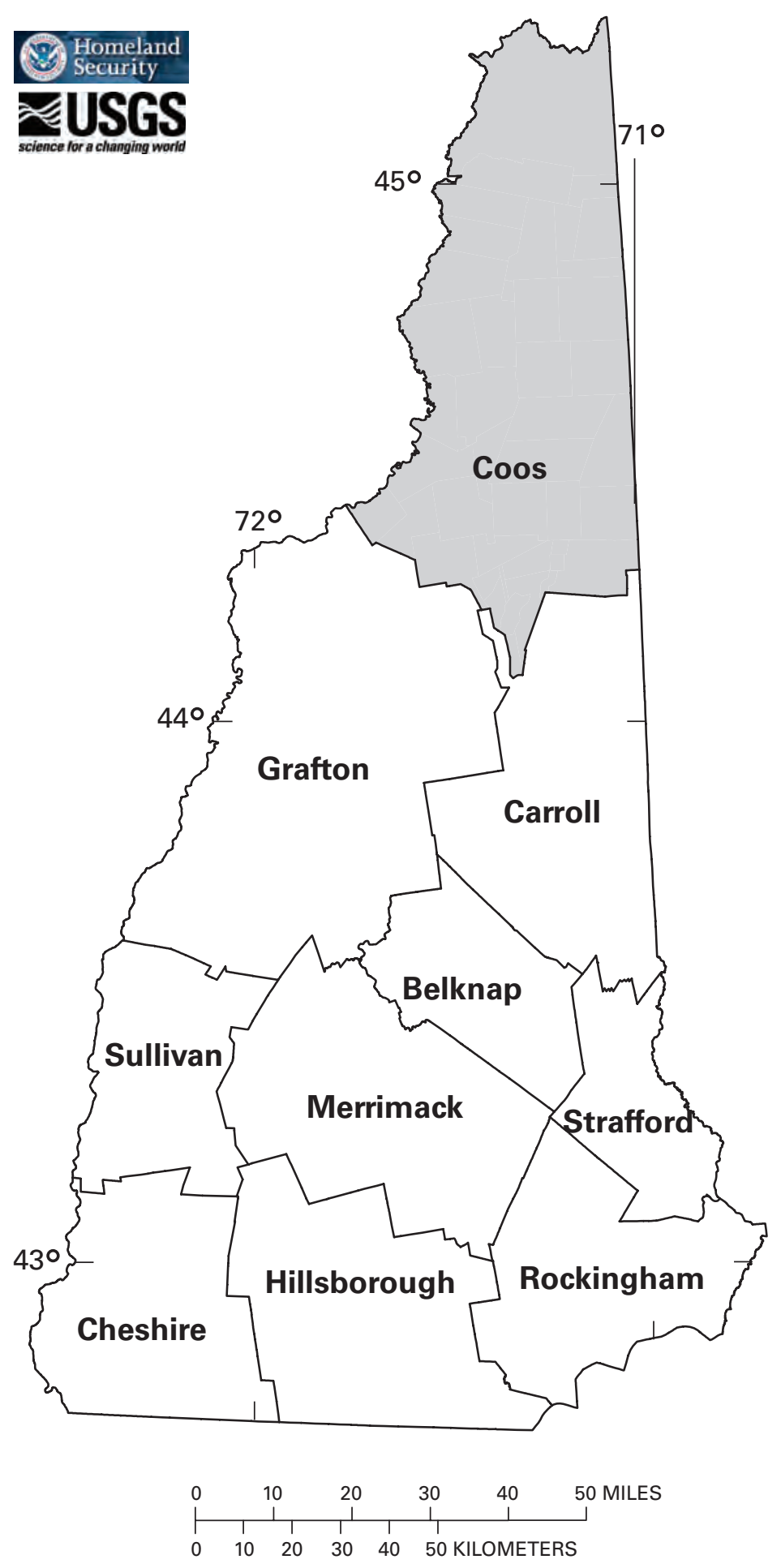

Figure 1. Coos County, New Hampshire, location map. 
EXPLANATION

Flood Insurance Rate zones (See page 7)

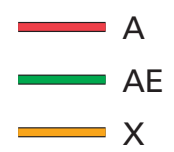
Hydrography

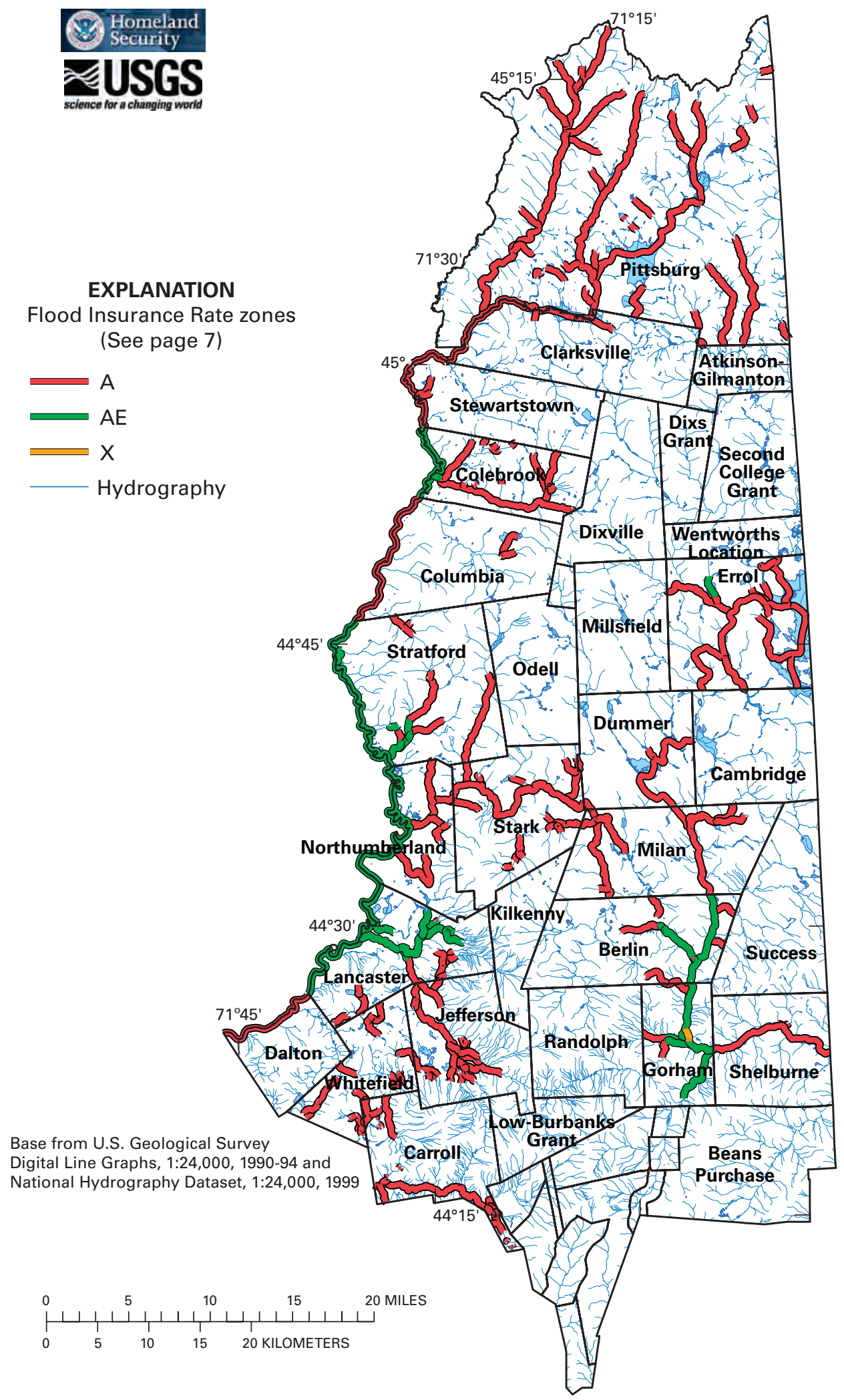

Base from U.S. Geological Survey

Digital Line Graphs, 1:24,000, 1990-94 and

National Hydrography Dataset, 1:24,000, 1999

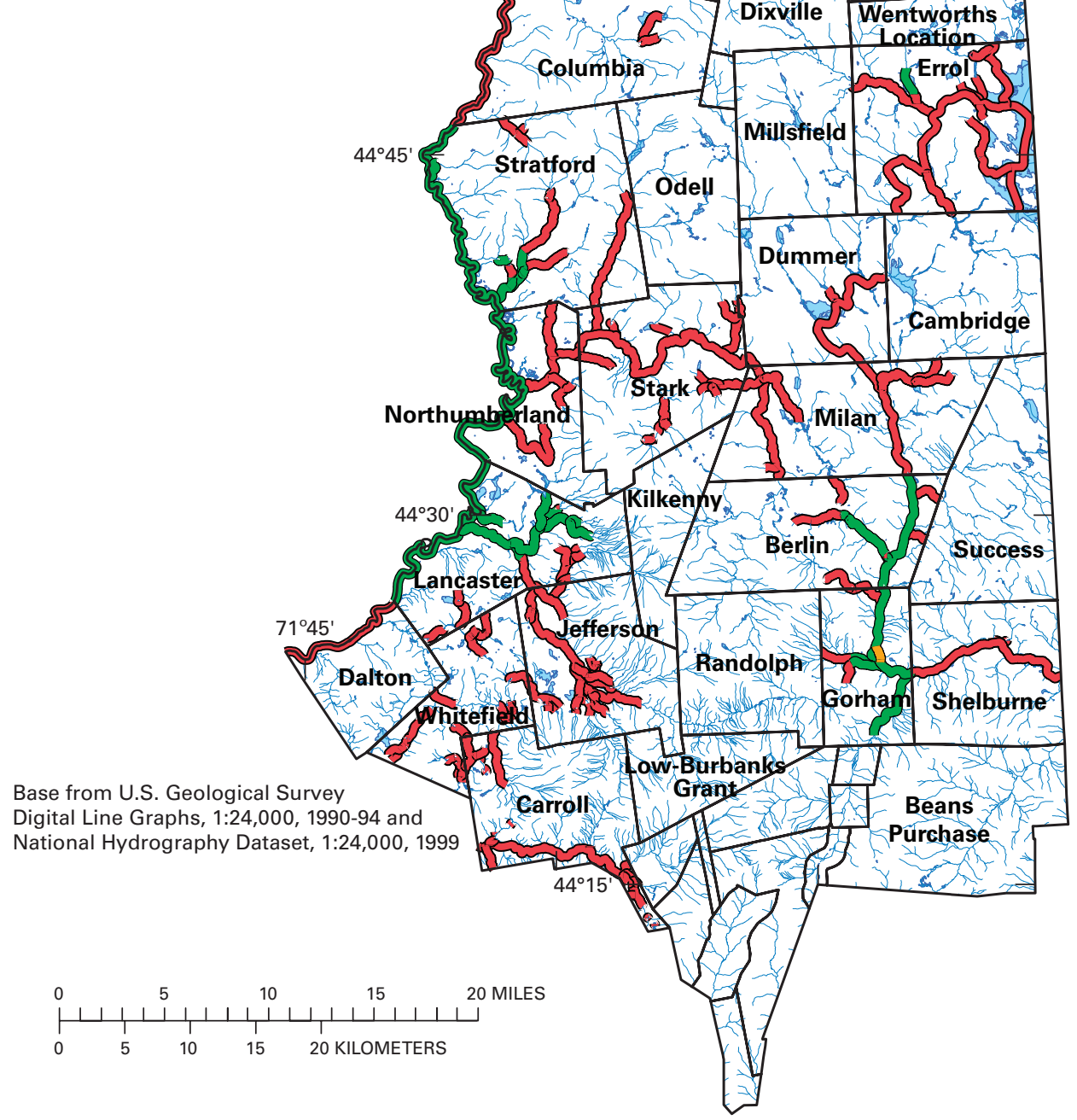

Figure 2. Coos County, New Hampshire, hydrography and FEMA Digital Flood Insurance Rate Map (DFIRM) data. 


\section{Section 2. Data Collected from Coos County Communities}

This section provides a summary of the data-collection efforts for communities in Coos County relating to the most recent community FISs and FIRMs; Letter of Map Amendments (LOMAs) and Letter of Map Revisions (LOMRs); information from the MNUSS database; and state and community meetings, and information on the location of existing remote-sensing data.

The flood-hazard information obtained in the data-collection efforts are summarized in figure 2 , and include:

- State, county, and community boundaries.

- Water features.

- Limits of existing detailed and approximate study within Coos County.

These maps can be continually updated in the future as new information becomes available.

\section{Community Flood Insurance Studies and Flood Insurance Rate Maps}

A summary of FIS and FIRM dates for the communities located in Coos County are listed in table 2.

Table 2. FIS and FIRM information for communities.

[SFHA, Special Flood Hazard Area; FIS, Flood Insurance Studies; FIRM, Flood Insurance Rate Map; FHBM, Flood Hazard Boundary Map; --, no data]

\begin{tabular}{llc}
\hline \multicolumn{1}{c}{ Community } & Date of entry & FIRM/FHBM date \\
\hline Berlin & $6 / 15 / 1982$ & $6 / 15 / 1982$ \\
Carroll & $4 / 15 / 1986$ & $4 / 15 / 1986$ \\
Clarksville & SFHA & $1 / 3 / 1975$ \\
Colebrook & $5 / 17 / 1989$ & $5 / 17 / 1989$ \\
Columbia & $4 / 2 / 1986$ & $4 / 2 / 1986$ \\
& & \\
Dalton & $12 / 15 / 1986$ & $12 / 4 / 1985$ \\
Dummer & $3 / 1 / 1995$ & $3 / 1 / 1995$ \\
Errol & $6 / 1 / 1995$ & $4 / 16 / 2003$ \\
Gorham & $4 / 1 / 1981$ & $5 / 2 / 1994$ \\
Jefferson & $4 / 15 / 1986$ & $4 / 15 / 1986$ \\
& & \\
Lancaster & $4 / 13 / 1973$ & $4 / 1 / 1982$ \\
Milan & $4 / 2 / 1986$ & $4 / 2 / 1986$ \\
Northumberland & $5 / 4 / 1989$ & $5 / 4 / 1989$ \\
Pittsburg & SFHA & $1 / 7 / 1977$ \\
Randolph & SFHA & $1 / 3 / 1975$ \\
Shelburne & $4 / 2 / 1986$ & $4 / 2 / 1986$ \\
Stark & $4 / 2 / 1986$ & $4 / 2 / 1986$ \\
Stewartstown & $3 / 1 / 2000$ & $3 / 1 / 2000$ \\
Stratford & $4 / 18 / 1983$ & $4 / 18 / 1983$ \\
Whitefield & $4 / 2 / 1986$ & $4 / 2 / 1986$ \\
\hline
\end{tabular}


The effective map dates range from 1975 in the Towns of Clarksville and Randolph to 2003 in the Town of Errol. Seventy percent of the FIRMs were produced prior to 1987 and will be 20 years old this coming year. The oldest FIRM is 31 years old, the most recent is 3 years old, and the average is approximately 19 years old.

\section{Delineation of Detailed and Approximate Study Areas}

Digital Q3 Flood Data have not been developed for Coos County to determine the areas of detailed study (Zone AE) and areas of approximate study (Zone A) within the communities. FEMA digital Q3 flood data is the electronically scanned currently effective map panels of an existing paper FIRM. Digital FIRM Data were created and provided by the University of New Hampshire Geographically Referenced ANalysis and Information Transfer system (UNH GRANIT) (Jenn Merriam, written commun., October 14, 2005) for this report. These data had not been quality checked by FEMA's contractors as of the date received. GRANIT, a collaborative effort between the University of New Hampshire and the New Hampshire Office of Energy and Planning (NHOEP), is a cooperative project to create, maintain, and make available a statewide geographic data base serving the information needs of state, regional, and local decision-makers. Definitions of flood insurance rate Zones $\mathrm{A}$ and $\mathrm{AE}$ are provided below:

- Zone AE: Zone AE is the flood insurance rate zone that corresponds to the 100 -year flood plains that are determined in the FIS by detailed methods. In most instances, whole-foot base flood elevations (BFEs) derived from the detailed hydraulic analyses are shown at selected intervals within this zone.

- Zone A: Zone A is the flood insurance rate zone that corresponds to the 100 -year flood plains that are determined in the FIS by approximate methods. Because detailed hydraulic analyses are not performed for these areas, no BFEs or depths are shown within this zone.

- Zone X: The flood insurance rate zone that corresponds to areas outside of the 500-year flood plain, areas within the 500-year flood plain, and to areas of the 100-year flood plain where average depths are less than 1 foot, areas of the 100-year flooding where the contributing drainage area is less than 1 square mile, and areas protected from the 100-year flood by levees. No BFEs or depths are shown in this zone.

\section{Letters of Map Change}

A LOMC is a letter issued by FEMA in response to a request to revise or amend an effective NFIP map to remove a property or reflect changed flooding conditions on the effective map. LOMCs may include LOMAs and LOMRs, as defined below:

- LOMAs: A LOMA is an official amendment, by letter, to an effective NFIP map. A LOMA establishes a property's location in relation to the Special Flood Hazard Area (SFHA). There is no appeal period for LOMAs, and the letter becomes effective the date that it is sent.

- LOMRs: A LOMR is an official revision, by letter, to an effective NFIP map. A LOMR may change flood insurance risk zones, flood plain and(or) floodway boundary delineations, planimetric features, and(or) BFEs. The effective date of a LOMR depends on the type of change requested. For example, some LOMR's are effective on the date that the letter is issued and others become effective following an appeal period (typically 30 to 90 days or 6 months). 
- LOMR-F: A Letter of Map Revision based on Fill (LOMR-F) may be filed as a special case of the LOMR. A LOMR-F provides FEMA's determination concerning whether a structure or parcel has been elevated on fill above the BFE and excluded from the SFHA. A LOMR-F is an official revision, by letter, to an effective NFIP map. The letter becomes effective on the date that it is sent.

In addition to the categories above, conditional LOMAs, LOMRs, and LOMR-Fs may be issued by FEMA to comment on a proposed project. The letter does not revise an effective NFIP map, but indicates whether the project, if built as proposed, would be recognized by FEMA.

\section{Letters of Map Change in Coos County}

LOMCs were collected for each of the communities.

A summary of the LOMCs obtained from FEMA (http://msc.fema.gov) and the NHOEM is provided in appendix A. The summary table in appendix A includes the LOMC case number, effective date, flooding source, location, area/structure removed from SFHA, and new flood zone. The location of each LOMC is shown in figure 3. 


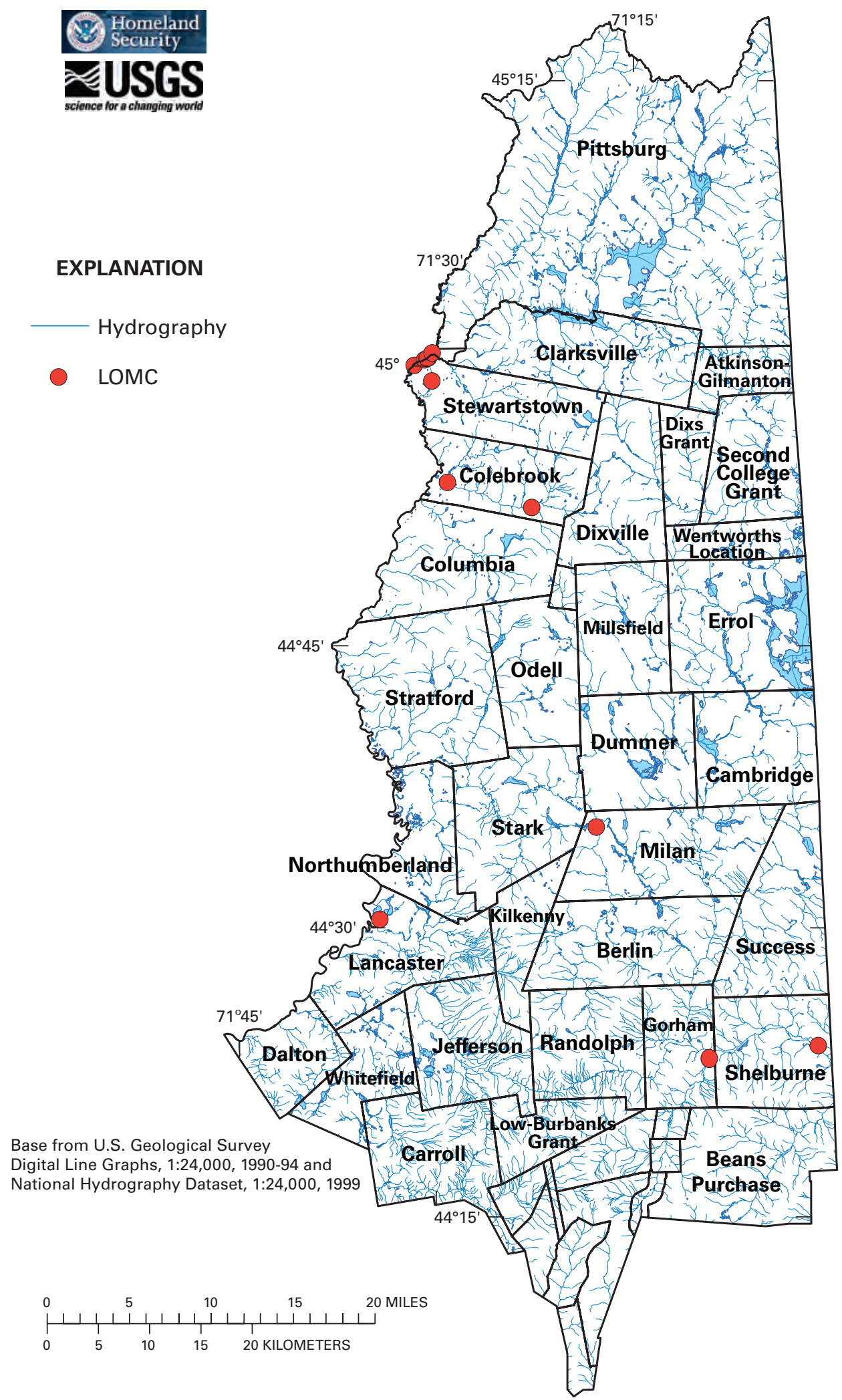

Figure 3. Letter of Map Change (LOMC) and community location map in Coos County, New Hampshire. 


\section{Mapping Needs Update Support System}

In accordance with section 575 of the National Flood Insurance Reform Act of 1994, FEMA assesses "...the need to revise and update all flood plain areas and flood-risk zones identified, delineated, or established based on analysis of all natural hazards affecting flood risks." FEMA initiated the Mapping Needs Assessment (MNA) process, which identifies and prioritizes flood-hazard mapping needs for communities nationwide. As part of this effort, FEMA developed the MNUSS, which is an interactive, web-based software application that maintains an inventory of needs for future map updates. In particular, MNUSS stores information on the following two types of update needs:

- Map Maintenance Needs: Includes changes to base map information, such as the addition of new roads, changes to corporate limits, and incorporation of LOMCs.

- Flood Data Update Needs: Includes changes to flood-hazard areas as a result of changes in H\&H conditions, changes to BFEs, and(or) changes in the flood plain delineation.

Mapping needs may be viewed and entered into MNUSS by a variety of parties, including FEMA Headquarters and Regional offices, state NFIP coordinators, study contractors, CTPs, and other Federal agencies, such as the U.S. Army Corps of Engineers (USACE) and the USGS. All needs are reviewed and approved by the FEMA MNUSS controller prior to office entry into the system.

\section{Mapping Needs in Coos County, New Hampshire}

Information on mapping needs for the respective communities within Coos County was downloaded from MNUSS on April 19, 2006, and is included in appendix B. This information included a summary of those communities that had and had not responded to requests for information on MNUSS mapping needs, as well as a summary of the map maintenance and flood-data-update needs, as appropriate, for those communities where responses had been received. A summary of the response status for each community and the general mapping needs are listed in appendix table B-1. Information on the specific community mapping needs is provided in table 3 . 
Table 3. Summary of specific mapping needs in Coos County, New Hampshire.

[BFE, Base Flood Elevation; LOMCs, Letters Of Map Change]

\begin{tabular}{|c|c|c|c|}
\hline Community & $\begin{array}{l}\text { Need } \\
\text { identifier }\end{array}$ & $\begin{array}{l}\text { Study } \\
\text { category }\end{array}$ & Comments \\
\hline Berlin & 10575 & Riverine & $\begin{array}{l}\text { Changes to flood plain width with an anticipated BFE decrease of between } 1 \text { and } \\
5 \mathrm{ft} \text { over } 0.35 \mathrm{mi} \text { on the Androscoggin River on panel 017B. }\end{array}$ \\
\hline Berlin & 29275 & Maintenance & Add streets to panels 004B, 005B, 006B, 010B, 011B, 012B, 016B, and 017B. \\
\hline Berlin & 29276 & Riverine & $\begin{array}{l}\text { Changes to hydrologic conditions, hydraulic analysis and flood plain width with } \\
\text { an anticipated BFE increase of less than } 1 \text { foot over } 0.3 \mathrm{mi} \text { on the Dead River } \\
\text { (from Pleasant Street to the confluence with the Androscoggin River. }\end{array}$ \\
\hline Colebrook & 10614 & Riverine & $\begin{array}{l}\text { Changes in hydraulic analysis with an anticipated BFE decrease of less than } 1 \text { foot } \\
\text { over } 5.85 \mathrm{mi} \text { on the Connecticut River on panel 010B. }\end{array}$ \\
\hline Colebrook & 10612 & Riverine & $\begin{array}{l}\text { Changes in flood plain width with an anticipated BFE increase of greater than } 5 \mathrm{ft} \\
\text { over } 10.98 \mathrm{mi} \text { on the Mohawk River on panels } 005 \mathrm{~B} \text { and 010B. }\end{array}$ \\
\hline Colebrook & 10613 & Riverine & $\begin{array}{l}\text { Changes in flood plain width with an anticipated BFE increase of greater than } 5 \mathrm{ft} \\
\text { over } 3.33 \mathrm{mi} \text { on the North Branch Mohawk River on panel 005B. }\end{array}$ \\
\hline Colebrook & 10611 & Riverine & $\begin{array}{l}\text { Changes in flood plain width with an anticipated increase of greater than } 5 \mathrm{ft} \text { over } \\
7.46 \mathrm{mi} \text { on the West and East Branch on panel 010B. }\end{array}$ \\
\hline Dummer & 10577 & Riverine & $\begin{array}{l}\text { Changes in hydraulic analysis with an anticipated BFE increase of greater than } \\
5 \mathrm{ft} \text { over } 8.3 \mathrm{mi} \text { on the Androscoggin River on panel } 3302019999 .\end{array}$ \\
\hline Dummer & 10576 & Maintenance & Add LOMCs to panel 3302019999. \\
\hline Errol & 10579 & Riverine & $\begin{array}{l}\text { Changes in hydrologic conditions with an anticipated BFE increase of greater } \\
\text { than } 5 \mathrm{ft} \text { over } 45.45 \mathrm{mi} \text { of all Zone As. }\end{array}$ \\
\hline Gorham & 25967 & Riverine & $\begin{array}{l}\text { Changes in flood plain width with an anticipated BFE increase of less than } 1 \text { foot } \\
\text { over } 0.45 \mathrm{mi} \text { along the Androscoggin River on panel 010C. }\end{array}$ \\
\hline Jefferson & 10627 & Riverine & $\begin{array}{l}\text { Changes in hydraulic analysis with an anticipated BFE increases of greater than } \\
5 \mathrm{ft} \text { over } 10.77 \mathrm{mi} \text { on the Israel River. }\end{array}$ \\
\hline Shelburne & 15558 & Maintenance & Add streets to panels. No panels have been associated with this need. \\
\hline
\end{tabular}

As shown in table 3, a total of 13 mapping update needs are listed in MNUSS throughout Coos County. These include three map maintenance needs and ten flood-data-update needs. Not all of the communities in the county responded to the FEMA request for information regarding mapping needs, so the actual number of mapping needs may be higher than what is currently reported in MNUSS. Additional information on mapping needs in the communities was established through state and community meetings, as discussed in the following sections. 


\section{State and Community Meetings}

As part of the scoping effort, the USGS conducted a series of meetings with the following State agencies and communities:

- NHOEM on August 24, 2005, to review LOMCs.

- Conference call kick-off meeting with NHOEM, FEMA, USGS, and Watershed Concepts on September 1, 2005.

The following section provides a summary of the key outcomes from each of the State and community meetings. Additional detail is given in appendix $\mathrm{C}$, which provides copies of the meeting minutes and an example community interview form.

\section{Meeting with New Hampshire Office of Emergency Management(NHOEM) and Scoping Team Members}

USGS held a kick-off meeting with a conference call on September 1, 2005, that included representatives from NHOEM, FEMA, USGS, and Watershed Concepts (RMC - Regional Management Center). The meeting was used to introduce the scoping project team and review roles and responsibilities. The meeting agenda and minutes are included in appendix $\mathrm{C}$. The following people were included in the meeting:

- Dean Savramis, representing FEMA, provided an overview of the Map Modernization Program and Scoping. He also provided a description of the countywide approach.

- Brent McCarthy (RMC) described the role of the RMC in assisting FEMA and the mapping contractors. He described the Watershed Information System (WISE) (Watershed Concepts, 2005) computer applications developed for FEMA to standardize the scoping process methodology, data collection, and storage for the map modernization program. Brent mentioned that it may be a good idea to set up a morning and evening meeting with each County in order to be able to talk to all of the representatives in each town (two meetings for each county). Brent also mentioned that Watershed Concepts could lead breakout sessions with towns during the meetings with the Counties.

- Jeff Burm (RMC) spoke about the WISE Scoping tool and various features of this tool including community contact information, available GIS data, stream data, statistical analysis, stream mile information to calculate costs for hydrology and hydraulics, LOMAs, CAVs and Community Assistance Contacts (CACs), creation of reports for each of the items.

- Fay Rubin (UNH GRANIT), Craig Johnston, Laura Hayes and Robert Flynn (USGS)—discussed available data and coverages within New Hampshire (for example, 2003 National Agriculture Imagery Program (NAIP) color Digital Orthophoto Quadrangles (DOQs)). Remote sensing, base map information, GIS data (for example, contour data, E911 data, Digital Elevation Model (DEMs), buildings layer, survey data available from the New Hampshire Department of Transportation (NHDOT). In addition, the county regional planning commissions were mentioned as possible sources of data. 


\section{Coos County Community Meetings}

Conference calls were conducted with representatives from all of the towns in Coos County. The following sections provide a brief summary of the key findings from each community interview, and in particular, identifying areas with increased development, areas with known flooding problems, and areas with changes to hydraulic structures. The applicable community contacts are also provided in each section.

The goals of these meetings were to:

- Inform the communities of the nature and the intent of the flood map update process.

- Solicit community input and discuss the flood-prone areas that communities would like to include as a part of the flood map update.

Community comments were captured on paper interview forms, FIRM panels, and on working maps of each community produced for this purpose. These comments were entered into the WISE scoping application. Notes from the working maps and FIRM panels are summarized on figure 3. For communities not represented at the meetings, information provided by NHOEM, and contained in the community business plan was relied upon.

\section{Coos County:}

\section{Berlin}

The following provides a summary of the key issues identified during the community interview November 15, 2005):

- On panel 17, a detailed study is needed along the Dead River. Dead River flows under part of Pleasant Street and flows between main buildings on this street. The current map is limited in detail and there is planned future development in this area. The river is undermining building and causing erosion in the river channel. The town has questions about what is going on in the river and want the 100 -year flood plain boundary updated to current conditions. The river is shown as segmented on the panel but the river is never dry and is not contained within a culvert. This covers about a $400 \mathrm{ft}$ reach. At the junction of Pleasant Street and Main Street both bridges have been reconstructed in the 1980s and 90s.

- On panel 17, Community Street does not cross the Androscoggin River but ends at the river bank.

- On panel 17, A new bridge (James Cleveland Bridge) was built in 1983 across the Androscoggin River between BFE 925' and 926'. Unity Street runs into the new James Cleveland Bridge and does not show up on the panel. Unity Street was built parallel to the Access Road and the railroad that runs east of the river.

- On panel 17, Gorham Road should be labeled Route 16 and the road off of Route 16 in the southern part of the panel is called Glen Avenue.

- On panel 11, the high school complex is located at the end of Madison and Willard Avenues. An unnamed stream runs through this area and the town would like to have the flood boundary in the area along the Dead River checked to make sure it is accurate.

- Landmarks are not easily identified. 
- Street names were changed July 1, 2005. These changes are not on the tax maps currently but will be added.

- The Town of Berlin has GIS capabilities.

Contact: Pamela LaFlamme, City Planner (752-1630).

Carroll

The following provides a summary of the key issues identified during the community interview (August 25, 2005 and February 7, 2006):

- On panel 13, multiple roads need to be added between the Little River and the corporate limits.

- On panel 13, south of Route 3 (where Little River crosses Route 3), there is an island in the river that does not show up on the current FEMA map.

- On panel 13, Roads and development north of Profile Road between corporate limits and Little River and between Little River and intermittent stream to the east and north of Profile Road Area at the end of Birch Road is developed near the Zone A boundary and needs to be remapped. A detailed study is needed along the Ammonoosuc River due to development along the southern overbank.

- On panel 14, a new state bridge was built across the Ammonoosuc River in the southeast corner of the panel. A new road, named "Zealand Trail," extends along the Zealand River from the bridge to the corporate limits in the southern part of the panel. Two campgrounds exist along the Zealand Trail Road.

- On panel 14, the town bridge from Dartmouth College Road to River Road, in the northwest corner of the panel, over the Ammonoosuc River, is scheduled to be replaced by 2012. A detailed study is needed along the Ammonoosuc River in this area continuing from panel 13 to the southern end of Lake Road.

- On panel 15, a new road named "Lower Falls Road," runs parallel to the Ammonoosuc River (Zone A) from the western edge of the panel to Cherry Mountain Road. A detailed study is needed from the Zealand Trail Road panel 14 to Cherry Mountain Road.

- On panel 17, a bridge built in 1901 does not show up on the current panel. The road joins Route 302 and heads northeast through a golf course to the edge of the panel. There is a newly approved 43 unit and 9 house development off of the golf course from Route 302 toward the Zone A of Crawford Brook northeast of Route 302 midway between the Crawford Brooks intersection with Route 302 and an unnamed intermittent tributary to the west.

- On panel 6, Straw Road needs to be extended by $400 \mathrm{ft}$. Woodland Acres Road needs to be added in the southwestern corner between an unnamed stream and Carroll Stream (south of Route 3).

- On panel 10, Zone A appears ok but need to add Woodlands Acres Road in Zone C in northwest corner of panel, add Twin View Drive off of Route 3 in lower southwest corner of panel between Route 3 and the railroad tracks, and add Sunset Ledge off of Route 115 south of Carroll Stream.

- On panel 13, Profile Road should be labeled Birch Road and Ruth Road needs to be added.

- On panel 14, need to add Mountain View Lake Road where Town bridge crosses Ammonoosuc River to Profile Road, School Street where town offices are located north of the Ammonusuc River off of Dartmouth College Road are, and, need to change Colebrook Pond Road to Fieldstone Lane. 
There is also extensive road and development off of St. Margarets Street that runs between Tyler Brook and an unnamed intermittent brook to the east.

- On panel 15, need to add an extensive road system from development north of Base Road in lower southeast corner of the panel and add Crawford Ridge Road southeast of Crawford Road running parallel to the Ammonoosuc River.

- Town does not yet have GIS capabilities. Town tax map layer was done by Cartographics Company. There is a proposal submitted for voters at the March 06 town meeting to purchase hardware and GIS software so capabilities will depend on the outcome of the vote. Tax map by Cartographics Company for April 1, 2005, was provided to USGS by Allen Strasser.

Contact: Allen Strasser, Town Selectman (846-5754) and Vicki Brodeur, Administrative Assistant (no longer working for the town).

\section{Colebrook}

The following provides a summary of the key issues identified during the community interview (September 7, 2006).

- On panel 5, there is no connection between Beaver Brook and the Mohawk River flowing from east to west near Zone $\mathrm{X}$ between Corliss Lane and Pleasant Street. There is a golf course with less than $1 \mathrm{mi}$ of lawns. A trailer park and lumber yard are in this area but the pond has disappeared.

- On panel 5, Route 26 (crossing Route 145, before Beaver Brook) was reconstructed and development in the area may have changed elevations due to fill that was brought in near the Zone A area along the Mohawk River and Route 145, just northwest of Park Street. A detailed study is needed along Beaver Brook from its confluence with the Mohawk River to Hughes Road and along the Mohawk River from its confluence with the Connecticut River to 2,000 ft upstream of Route 26.

- On panel 5, fill was brought in at the confluence of the Mohawk and Connecticut Rivers.

- On panel 5, flood mapping appears to be inaccurate at the location of BFE 1,008' on the Connecticut River. There is an industrial park north of that area.

- On panel 5, there is a LOMA on file indicating that a portion of the Colebrook Golf Course property was removed from the flood zone.

- On panel 10, there is a LOMA on file indicating that a structure owned by Mr. Germain, at RFD \#1 Box 103, should be removed from the flood zone along the Mohawk River. The structure sits on a cliff and has never been in the flood zone. The current 1989 map indicates Zone A includes his property. The Zone A flood map needs to be corrected in this area (between Russell Road and H Cross Road on the Mohawk River, approximately 200-500 ft downstream of the confluence of Roaring Brook and Mohawk River).

- The GIS layers available to the town are tax maps. Money has been set aside to bring GIS capabilities to the town. The town has wildlife, small tributaries, forest layers available along the Connecticut River through John Severance, North County Council (603) 444-6303. The town does have E-911 roads data.

Contact: Donna Caron, Town Manager (237-4142) 


\section{Columbia}

The following provides a summary of the key issues identified during the community interview (November 17, 2005):

- On panels 1 and 3, the Connecticut River floods along this reach and a detailed study is needed from the Columbia Bridge (a covered bridge that spans the Connecticut River to Lemington, Vt.) south along Route 3 (for approximately $1.5 \mathrm{mi}$ ) to the confluence with Sweatt Brook. Route 3 is often threatened in this location and there is a sand/gravel and cement operation in this area.

- On panel 6, the delineation of the flood plain is questionable from Lyman Brook to the corporate limit. There is an old hydroelectric power dam and gas tanks are located in the areas between the railroad and Route 3.

- On panel 1, the town states that there is a trailer park in the area just north of Simms Stream and between the railroad tracks and Route 3 . They question whether this area may be in danger of flooding.

- The town requests that the railroad tracks that run through town be added to the new flood maps.

- The town would like to know if the gas tank farm located on Route 3 in Stratford is in the flood plain. This area is just south of Columbia on the Connecticut River.

- The town does not have GIS capability.

Contact: Bill Schomburg, Chair, Planning Board (237-5255)

Dalton

The following provides a summary of the key issues identified during the community interview (August 25, 2005):

- No new studies needed.

Contact: Dean Sweeney, Chair, Board of Selectmen, (837-2092).

Dummer

The following provides a summary of the key issues identified during the community interview (September 12, 2005 and April 10, 2006):

- On panel 1, the Special Flood Hazard Area (SFHA) in the southwest corner of the panel, from the corporate limits along the Upper Ammonoosuc River to Route 16 are high in elevation and should not be in the flood plain.

- On panel 7, from Route 110A east to the Public Park (Boffenger Recreational Area), the topography drops steeply to the river and southwestern bank of the Androscoggin River should not be in the flood plain.

- On panel 7, in the area north of Route $110 \mathrm{~A}$ along, and southwest of, Route 16, there is a 1,000 ft drop down to the river with a culvert that was replaced 5 years ago. This area should not be in the flood plain. 
- On panel 7, along Route 16 in the northwest corner of the panel for about a 2,000 ft reach, there is an area showing flooding from the Androscoggin River over Route 16. In this area, the topography drops off and Route 16 does not flood.

- On panel 7, at the $300 \mathrm{ft}$ label on the panel, there is a canal that flows into the Androscoggin River at the confluence where a hydroelectric dam was built in 1986. This canal is not reflected on the panel. The area west of this area is known as Wheeler Bay.

- On panel 7, in the southeast section near the edge of the map and south of the Androscoggin River, there is private land that never floods because the fields are at a higher elevation then the river. The owner wants to subdivide and do away with flood ordinance as he feels the boundaries are not correct. The hydro dam has controlled the river since 1991.

- On panel 10, in the southwest corner of the panel between the corporate limit boundary and the edge of the map along Route 16 (southwest of the Androscoggin River) is private area owned by the same person and is continued from Panel 07 (see previous bullet item). Concerns are still the same regarding inaccuracy of the flood boundaries.

- Based on the above items, a detailed study is needed along the Androscoggin River from the northern boundary of panel 7 to the corporate limit on panel 10 .

- On panel 2, Phillips Brook flows over Paris Road. There are seasonal camps across the road. A detailed study is needed in this location.

- On panel 11, a detailed study is needed along the Androscoggin River from $500 \mathrm{ft}$ west of the tributary (at annotation reading 600') to the corporate limit.

- The town does not have GIS capabilities but, there is a person in town that has a GIS and can help the town.

Contact: Brad Wyman, Chair, Board of Selectmen (449-2006) and Betty Hawkins, Board of Selectmen (449-2006).

Errol

The following provides a summary of the key issues identified during the community interview (November 16, 2005 and December 5, 2005):

- On panel 0030B, LOMA for 239 Akers Pond Road is believed to be accurate and property should be removed from the SFHA. Property currently sits in Zone A just south of Akers Pond.

- On panel 0030B, a detailed study is needed along the Androscoggin River from approximately $4,000 \mathrm{ft}$ south of the confluence with Clear Stream to approximately 4,000 ft north of the confluence with Clear Stream (approximately $1.5 \mathrm{mi}$ ). The study area is currently designated as Zone A. Study is needed as flooding occurred in this area and the town is currently buying up houses in the flood plain. In addition, two new bridges were built in town and the Route 26 center pier was removed (July 02).

- On panel 0030B, a detailed study is needed along Clear Stream from its confluence with the Androscoggin River to its confluence with the brook flowing south out of Akers Pond due to development along Route 26 and backwater effects from the Androscoggin River (approximately $1.2 \mathrm{mi}$ ) (July 02). 
- Road names are inaccurate on some of the 2003 FIRM panels. The following panels have no problems: 20, 40, 50, 60.

- Panel 25 has a mislabeled road. East Side Road should be labeled Colebrook Road-U.S. Route 26.

- Panel 30 has mislabeled roads: East Side Road should be labeled Colebrook Road-U.S. Route 26, White Mountain Road should be labeled Berlin Road-U.S. Route 16, Section of road from intersection of East Side Road with White Mountain Road should be labeled Main Street. Magallaway Road should be labeled Dam Road-U.S. Route 16 and 26a and Upton Hill Road should be labeled Upton Road-U.S. Route 26.

- Panel 35 has a mislabeled road. Magallaway Road should be labeled Dam Road-U.S. Route 16.

- Panel 55 has a mislabeled road. Upton Hill Road should be labeled Upton Road-U.S. Route 26.

Contact: Dottie Kurtz, Town Administrator (482-3351).

Gorham

The following provides a summary of the key issues identified during the community interview (September 21, 2005):

- On panel 10, there is Moose River and Moose Brook within the town limits. Flooding from the Moose and Peabody Rivers occurs from ice jams. Kate White, CRREL, has done an extensive study on the Peabody River.

- The town received three separate grants in 1999 for riverbank stabilization on the Peabody, Moose, and Androscoggin Rivers. Two grants were from a disaster declaration and the third was from FEMA's disaster resistance initiative, known as Project Impact. With these grants, riverbank stabilization (reconstructed berm with additional riprap and vegetation) was done at one site on the Peabody River and one site on the Moose River. These changes were deteriorating gabion baskets and were replaced with boulder deflectors and vegetation on the Androscoggin River. These changes were completed in 2002.

- On panel 10, parts of Bangor Street (along the Peabody River) need to be remapped as this area should be removed from flood Zone AE on current maps from 1994. A berm was built in 1988-89 on the east side of the river and since then, there has been no flooding in this section of the town. A LOMA for 48 Bangor Street is still valid.

- On panel 10, on the east side of the panel, the area between cross sections D and E on the Androscoggin River and including Alpine, Jewell, Willis Place, and Androscoggin Streets, does not flood and should be remapped. Area is labeled Zone AE and Zone X.

- On panel 10, the area along the Androscoggin River (south of cross sections F and G) between Church Street and Union Street in Zone X does flood. In 2002, in the area along the river just west of this area has had boulder deflectors and vegetation planted for about $150 \mathrm{ft}$.

- On panel 10, on the Moose River between cross section I and B, ice jams in the past flooded the area but riverbank stabilization in 2002 has reduced flooding. Area should be remapped.

- On panel 10, Moose Brook had a detailed study that was completed in 2002 by the USGS NH/VT Water Science Center. The extent of this study was from its' confluence with the Androscoggin River to Moose Brook State Park (approximately $2.2 \mathrm{mi}$ ). 
- On panel 5, Tinker Brook and Dead River area needs to be evaluated.

- On panel 5, the tributary to the Androscoggin River near Pisani Street has a 7-ft high box culvert at Main Street and does not flood.

- On panel 15, in the area between the cross section $\mathrm{O}$ and $\mathrm{S}$, a berm/riprap with vegetation stabilization project was completed since 1994 and may have changed the flood-plain boundary in this area.

- On panel 15, two housing developments have been built since the 1994 maps and are located at Stoney Brook Road and Marion's Way. These developments are located on the side of a mountain along Route 16 and should not be in the flood zone as shown on the panel.

- Many street name changes have occurred since the town changed to the E-9111 program and these are available from the town.

- Gorham has the following GIS layers: zoning, streets, tax map, wetlands, 100-year flood plain, 500-year flood plain, shoreland for the Androscoggin River, and hydrography of the town (Androscoggin, Peabody, and the Moose Rivers).

Contact: Heather Mortenson, Administrative Assistant, Deputy Emergency Management Department Hazard Mitigation Project Coordinator (466-5025).

Jefferson

The following provides a summary of the key issues identified during the community interview (August 24, 2005):

- On panel 1, on the Turnpike Road in the area between an unnamed road and Route 2 Junction, Turnpike Road is higher in elevation than the river and doesn't flood. The area between the river and Turnpike Road should be remapped.

- On panel 4, in the lower right hand corner, flood zone boundaries on the south side of the Israel River are too wide as this is the high elevation side of the river and never floods. The area to reevaluate is about a $500 \mathrm{ft}$ reach on either side of Route 116 south of Israel River. This area extends into the top of Panel 07.

- On panel 8, the area along Turnpike Road to Route 116A intersection is high in elevation and the flood plain boundary is too wide along the Israel River in this location.

- On panel 11, Route 115 extension was built to connect to Israel River Road. Where Route 115 crosses Cherry Mill Brook there is a new bridge. Another new bridge crosses an intermittent stream running through Zone A near the swamp area. A third new bridge was built crossing the Red Brook. This area should be remapped since the bridges were constructed from 1980 to 1985 but do not show up on this panel. The new Route 115 was continued across the Israel River and another new bridge was built. The old Route 115 is now called Stag Hallow Road.

- On panel 11, the area between Israel River Road and the Israel River on the east and west side of Route 115 is a high elevation, at about 1,000 ft in elevation, and the flood plain needs to be corrected in this location on the Israel River.

- On panel 11, where the intermittent unnamed stream crosses Route 115A, in the upper northwest corner of the panel, the flood-plain boundary is inaccurate as there is no flooding that occurs in this area. 
- On panel 12, old Route 115 becomes Stag Hollow Road and the new Route 115 needs to be added to the map in the northwest corner.

- Road names have been changed after Route 115 extension was built. The road east of where Route 115 crosses the Israel River is now called Valley Road.

- Town does not have GIS capabilities but would consider the option if there as a GIS coverage of the flood maps.

Contact: Linda Cushman, Assistant to the Board of Selectman (603-586-4553)

Lancaster

The following provides a summary of the key issues identified during the community interview (November 16, 2005):

- On panel 5, LOMA is correct and still applies for residential structure at 22 Stockwell Road, which should be removed from the flood zone. Area of about 1,000 ft on north side of Stockwell Road never floods due to high topography.

- On panel 5, between Summer Street and Depot Street there is a new bridge and culvert (2002) on Summer Street and an old culvert on Depot Street that needs repair. Town is looking for funding to replace this culvert. Trailers are located between Summer Street and 459 on Causeway Street that may be affected by floods with the new bridge.

- On panel 5, in the southwest corner of the panel, along Water Street from edge of panel to the Main Street bridge, there was a dam removed 2 years ago near the Water Street crossing. Ice jams occur where water backs up $3 \mathrm{mi}$ of the Israel River. A dam was removed near the 869 mark a long time ago. All this activity is upstream of the covered bridge.

- On panel 5, a restudy is requested on the ice-affected profile of the Israel River. Annually, the town is flooded along the banks of the Israel River, which has affected homes and businesses in the community. The town wants a better understanding of the hydrology of the river and how flood stages occur to determine what to do to prevent the annual flooding. The ice-affected flood stages are not shown on the current maps.

- On panel 10, the covered bridge on the Israel River is having repair work done to it. The town is seeking permission to dismantle the dam at approximately BFE 893' and they want to know what effect this will have downstream. The flood zone to be re-evaluated is between BFE 893' and 895' near the covered bridge.

- On panel 10, Garland Road bridge has been replaced since 1982 and may change the flood plain boundaries on Otter Brook.

- On panel 11, Valley Road bridge was replaced in 2004 and may change the flood plain boundaries on Caleb Brook.

- On panel 16, an unnamed stream crosses Route 2 south of Wesson Road. There is commercial development between the railroad tracks and Route 2 near the brook and at the end of Wesson Road. The State rebuilt the culvert bridge on this unnamed stream and there has been some flooding recently.

- On panel 17, new development is located where North Road meets Gore Road for about $400 \mathrm{ft}$ on either side of that intersection. There is a culvert on North Road that crosses and unnamed stream. Zones may be O.K. but should be checked. 
- There is little development in the town.

- Kathleen White, CREEL, assessed the ice jam history of two reaches of the Connecticut River. CREEL also has monitoring devices on the river to monitor ice jams. One reach requires an update of the hydrology and hydraulics to accurately depict ice-affected flood profiles. The second reach did not require an ice-affected flood profile. Contact Kathleen at Kathleen.D.White@erdc.usace.army.mil (603) 646-4187

- The town does have GIS on a laptop. The town also has water and sewer map coverage and would definitely use a GIS coverage of the FIRM maps if it were available.

Contact: Joyce McGee, Town Manager (788-3391)

Milan

The following provides a summary of the key issues identified during the community interview (September 6, 2005):

- A detailed study was completed in 2002 by USGS NH/VT Water Science Center along the Androscoggin River from the upstream corporate limit of Berlin, N.H., to the downstream corporate limit of Dummer, N.H. A printed FIRM was sent to the town for any changes to be made. David Mendelsohn, FEMA, told the town that the revised map completion was on hold but that they could use the draft map they have in their possession as the most recent version. There were told that they would have to wait for Coos County to be completed. The town has agreement \#EMW2001IA-096 for this new map.

- On panel 10, (March 31, 2005 preliminary map) (panel 03 of 1986) - LOMA to remove structure at 127 Spruceville Road from the flood zone is still correct.

- No other changes were needed on the revised maps as of 2003.

- The town has been in touch with 6 people, 3 from FEMA and 3 from Concord about the delay. The Selectman have a letter from FEMA that says they can use the map they were sent for review. The town contacted Senator Sununu and he received a letter from FEMA indicating that FEMA was taking care of this map publication issue. The town was told that they were all set with a revised map last March by FEMA. Then they were told the project was on hold and that they would have to wait $4-5$ years so that the southern part of the State could be completed.

- The town does have E-911 but no GIS capabilities

Contact: Richard Lamontagne, Chairman, Board of Selectmen (449-2484)

\section{Northumberland}

The following provides a summary of the key issues identified during the community interview (September 2, 2005):

- On panel 5, in north section of the panel, along Route 3 between Zone AE and Connecticut River BFE 865', houses along Ball Road are higher then Route 3 and a long way from the river. Section needs to be remapped.

- On panel 5, the Connecticut River meanders in the southwest part of the panel, which are changing the landscape. The river has eroded the banks in the horseshoe bends and about 3,000 ft of shoreline 
is affected. At the end of Craggy Road in Zone X, there is a race track that may have shoreline erosion.

- On panel 5, in the southern part of the panel along Route 3 from the start of the ballooned flood zone north along Route 3 to where the railroad tracks cross the river, the river channel is re-carving in this southern 4,000 ft section. The area of the houses around Roaring Brook Road off Winter Street, which then turns into Lost Nation Road, appears to be in the flood plain. There are houses near Zone A area (from where the railroad tracks cross the river along Route 3 to the start of the word Winter in Winter Street) that flood but do not appear to be in Zone A. The bridge on Brooklyn Street was washed out so the town wants to know if this area is still in the flood plain as indicated on the 1989 panel.

- On panel 5, an area of potential growth is off of Route 110 on the other side of the Potter Brook and runs parallel to Potter Brook and on to the Upper Ammonoosuc River along Brooklyn Street. The town has a question about whether this area is in a flood plain.

- On panel 5, there is no flooding along Route 3 from the railroad tracks to the panel boundary. The cemetery in this section does have flooding problems on occasion.

- On panel 5, potential growth exists along Brooklyn Street where the river curves as it heads north. The elevation is high to the east of Route 110 and the town wants to know if this area is in the flood plain.

- On panel 5, a revision of the hydrology and hydraulics of the Upper Ammonoosuc River channel is requested because Red Dam was breached in the early 1990s and the river channel has changed. The Dam was owned by a mill on Route 110 toward Berlin on the north side of the road. There used to be a retention pond behind the Dam but that is gone and currently, the water flows through a gravel area east and upstream of where the dam used to be. The Red Dam was breached and repaired after a hurricane and there is no retention pond anymore. The area north of the Dam is very dry with vegetation growing and sand banks. The Red Dam was maintained by Groveton Paper Board at the time it was breached. They no longer own the dam. Contact information for Groveton Paper Board is Roger Goulet, Environmental Manager (603) 636-3000. rogerg@ grovetonpapers.com. He is unable to supply any other information other than the dam was repaired.

- On panel 5, there is residential development from where the river forks along Cummerland Street for about 3,000 ft. The closest house is on the east side of the stream. The river channel has changed. There are three houses upstream from the Dam, on Bert Hollow Road on the same river off Emerson Road. One owner has a garage in the flood zone but the house is higher in elevation and not in the flood zone. There is no LOMA in the file.

- On panel 10, there has been a big commercial development since the 1989 maps. Three large stores were put in on Paris Road and built in the flood plain.

- On panel 10, there is an old mill on Old Village Road that is commercial/industrial property with a prospective buyer and the town needs to know the hydraulics and hydrology of this reach along the Connecticut River.

- On panel 10, a trailer park near Ames Plaza on Route 3 is close to Dean Brook. Dean Brook Drive parallels the brook behind the Ames Plaza. York Street along Dean Brook turns into a housing development in a cul-du-sac. A new culvert was built in 2003 from the cul-du-sac road to a new housing development. There are two new subdivisions with new building occurring and the town doesn't know if the culvert will change the hydrology of the area at the entrance to the development. 
The town has a question as to whether this development is in a flood zone. Development runs about $1,000 \mathrm{ft}$ parallel to Dean Brook.

- On panel 10, at the intersection of Page Hill Road and Lost Nation Road there is residential development that parallels Dean Brook on either side of both roads for about 1,000 ft on page Hill Road and 2,000 ft on Lost Nation Road. The town would like that flood area clarified because of the increase in development.

- The roads are not correctly identified on the current FIRMs.

- Town does have E-911 coverage.

- Town does not have GIS capabilities but, there was a December 2004 vote in town to have areal surveys done. This project will give the town digital photographs, buildings and different zoning layers, and a new zoning map to overlay flood plains.

- Contact Cartographic Associates, Littleton, N.H., for details on the GIS layers the town uses. Franco Rossi (GIS) at 1-800-322-4540

- GIS layers available-parcel fabric in digital file.

- Arc View is provided by Cartographic Associates to the town, but town may decide to provide this software in the future.

Contact: Elaine Gray, Deputy Tax Collector, Town Clerk, Zoning, Planning, and Building Permit Assistant; map locations given by Becky Craggy, Administrative Assistant (636-1450).

\section{Shelburne}

The following provides a summary of the key issues identified during the community interview (September 2, 2005):

- Maps are difficult to read and the town can't locate properties on the maps so the town does not use the FIRMs. They have written often to complain and George Mussler visited to discuss the problem of the unreadable maps. There were culverts on an earlier map, but they don't show up on the most recent map and changes requested are not on the maps.

- On panel 2, bank work was done on a 1,000 ft reach of the Androscoggin River up and downstream of the confluence of Pea Brook. There is a golf course on the south side of the river between the river and the railroad tracks but the flood zone here appears to be accurate on the map.

- On panel 5, Shadow Pond (south of Route 2) floods and is connected to Reflection Pond but there is no bridge. The topography dips down between the ponds. Reflection Pond is an artificial pond created from the dam on the Androscoggin River and the current map shows flooding to be okay as is. When flash boards are not lifted in the dam, the pond floods Route 2. Reflection Pond has an earthern levy.

- On panel 5, immediately northwest of the North Road bridge on the banks of the Androscoggin River there is a private house out of the flood plain but it should be in the flood plain.

- On panel 7, the village is not in a flood plain but there is flooding in the town from Clement Brook every year in the area of the park and town hall between the railroad tracks, Village Road, and U.S. Route 2 and it extends northwest from Meadow Road. The map does not show this as a flood plain. 
If it rains, Androscoggin River will rise and there is backwater up Clement Brook for about 4,000 ft. If there is an ice jam on the Androscoggin River, Clement Brook backs up and floods.

- On panel 7, Northeast of the Meadow Road bridge, the flood plain does not extend across the road. During high water or ice jams, the road can flood between banks of the Androscoggin and North Road.

- On panel 7, a manmade channel, between Village Road and U.S. Route 2, blocks up every year. The State dredges it annually. The bridge on Village Road has "two boxes" and traps trees and breaks up ice jams.

- On panel 7, development is occurring in the area of Losier Road and flooding can extend to the road. A cul-de-sac at the end of Losier Road floods from East Brook during rain or high water from the Androscoggin River.

- On panel 7, some roads are not labeled correctly.

- On panel 11, there is a LOMA for 1333 State Route 2 (residential structure) that is believed to be accurate and the structure should be removed from the flood Zone A and placed in flood Zone C. House is above the river but land extends to the river.

- On panel 11, a 500-ft stretch on U.S. Route 2 never floods. The Androscoggin River never crosses Route 2 but the panel shows that it does.

- On panel 11, in the southeast corner of the panel, the Androscoggin River floods to the railroad tracks but, never over the tracks or to Route 2. The Androscoggin River backs up Connor Brook but does not cross Connor Road. There is a need to re-evaluate a 2,000 ft reach in this section.

- On panel 11, along North Road (north of the Androscoggin River) from Ingalis Valley Road and west to approximately $1,000 \mathrm{ft}$, Wheeler Pond does flood but not from the Androscoggin River. There is a culvert that causes flooding through a pipeline corridor from runoff uphill.

- The town requests a face-to-face meeting before any survey begins so they can point out certain areas to fix and which roads are needed on the map.

- Some roads are labeled incorrectly. Two-thirds of the roads in town are not on the maps.

- The town does have E-911, which was mapped for the town. The town will benefit from the availability of digital coverage

Contact: Josephine Carpenter, Administrative Assistant (466-2262)

Stark

The following provides a summary of the key issues identified during the community interview (January 31, 2006):

- On panel 10, the biggest problem for the town is a section of Route 110 along a 2,000 $\mathrm{ft}$ reach of the Upper Ammonoosuc River from the top of the panel south to the covered bridge. This area has some Zone A areas that are 1,000 ft or higher and do not flood. Current maps show this area to be in the flood zone.

- On panel 5, a dam went out in 1969 in Nash Stream but the dam was not rebuilt, therefore, the hydraulics of the river channel have changed. The area does not flood. At the intersection of North 
Road and Nash Stream a new bridge was put in after the dam broke. An area about 1,000 ft of reach should be resurveyed and have a detailed study.

- On panel 7, Pike Pond has a conservation easement surrounding it so there is no development. In the lower southeast corner of the panel, the Phillips Brook parallels Paris Road. At the bend in the road south of Dewey Road, the section of road (in 2000) was built up $14 \mathrm{ft}$, creating a levee that prevents the road from flooding. The reach is about $1,000 \mathrm{ft}$.

- On panel 7, in the Zone A area south of the railroad tracks in the southeast corner, a 77-foot long bridge was built in 2000 and the area no longer floods.

- The town would like to have someone come out and walk the Route 110 section north of the covered bridge before any revisions are made.

Contact: Joe Ike, Selectman and Sue Croteau, Office Manager (636-2118)

\section{Stewartstown}

The following provides a summary of the key issues identified during the community interview (September 22, 2005):

- The town has concerns about Murphy Dam at Lake Francis, in the Town of Pittsburg, upstream from Stewartstown. The Dam regulates flow but they wonder how that affects the flood zone in Stewartstown.

- On panel 1, most of the area from River Street to the end of Church Street is at least 75-100 ft above the Connecticut River along Route 3 (which follows the river). There are five houses on River Street that are above the river and are shown to be in the Zone A flood zone. It appears as if a broad brush was applied for approximately a 1,000 ft reach along the Connecticut River and high ground is shown to be in the flood Zone A. At the end of Church Street the drop off to the river is about $75 \mathrm{ft}$. LOMAs are thought to be accurate for residences at 1105 Route 3 and 1099 Route 3 and these should be removed from the flood zone because as the road follows the Connecticut River, it is higher in elevation than the river. LOMA for Pierre Road (leads to a subdivision called Fort Hill), which was built on the bank $75 \mathrm{ft}$ above the river off of Route 3 and it is thought that this residence should also be out of the flood plain.

- On panel 1, there is new development along Day Brook (near where it intersects Route 3) and an evaluation of the boundaries of the flood plain would be helpful to the town.

- On panel 1, the river bank drops off along Route 3 from the confluence of Day Brook with the Connecticut River at the modified dam to where the railroad tracks cross the river. The town feels that this area should not be in the flood plain.

- On panel 1, there is a LOMA for Fort Hill Road. This site needs to be removed from the flood zone as the building location is more then $100 \mathrm{ft}$ above the river.

- On panel 1, the area along Mill Street between the river and Route 3 (near the bend in the river) is greater then $75 \mathrm{ft}$ above the river and is shown to be in the flood plain. A new bridge was built in 2000 in the same area as the old one on Main Street. Park Street, in the same area, is 50-75 ft above the river and Rancor Street off of Park Street is greater then $75 \mathrm{ft}$ above the river. All are shown as being in the flood plain and they are not. 
- On panel 1, Back Pond Road (that crosses Day Brook) has a LOMA at 242 Back Pond Road. Some of the road was in a flood in the past but the town believes that it is no longer in the flood plain and needs to be removed from Zone A. The grade of the land increases in the Special Flood Hazard Area along Crown Road. At the point where Crown Road crosses Day Brook, there is a culvert and bridge with no flooding in this location.

- On panel 1, Back Pond is a spring-fed pond and the town questions whether the boundaries drawn around the pond are accurate because it is a wetlands or swamp area and is not directly connected to the Connecticut River.

- On panel 2, along Route 3, there is a development on a mountainside with new structures next to the Bishop Brook crossing of Route 3 so the area should be remapped. In October 2005, the brook flooded up to the Route 3 Bridge and the Zone A boundary is not shown on the panel. There are new commercial buildings on the bank of the river where the brook meets the Connecticut River. Any development along Route 3 is on the mountain side of Route 3 and high above the river.

- The town does not have GIS capabilities but they do have E-911.

Contact: Charles O. Stevens, Chairman, Board of Selectmen and Perry Richardson, Selectman (246-3329)

\section{Stratford}

The following provides a summary of the key issues identified during the community interview (September 12, 2005):

- One area for a property in North Stratford shows that a garage is below the base flood elevation according to the FIRM. No LOMA is on file, just a letter from the consulting firm Provan and Lorber. However, the flood boundary on the map does not extend beyond Route 3 yet, this garage is $1.5 \mathrm{ft}$ higher than Route 3. The flood map needs to be updated in this area. A letter from private surveyor indicated that the building was in the flood plain but the maps show the building is not in the flood plain.

- The town questions whether a tank farm on Route 3 is in the flood zone or not.

- On panel 5, from the top of panel for about $1.5 \mathrm{mi}$ southwest along the Connecticut River there are areas in which the town believes the Zone A to be inaccurate.

- On panel 5, at BFE 932'-930', Zone B is shown to extend across Route 3. The town feels that it may not be accurate.

- On panel 5, at BFE 928', there is a snack bar on high side of river.

- On panel 5, at BFE 928'-924', Lyman Brook is not labeled.

- On panel 5, at BFE 923' (near Zone A10), there is an oil storage company and the town is not sure if that is in the flood plain or not.

- On panel 5, from Paradis Road Zone B there is a development up on a hill in the area marked Zone B that should not be in the flood plain.

- On panel 5, Woodfield Road should be labeled Woodale Road.

- On panel 5, property location for Elevation Certification for Robinson property is between Zone B and Washburns Road. Certification states garage slab elevation is $886.12 \mathrm{ft}$ or not above the $888 \mathrm{ft}$ 
on the FIRM map. The map doesn't extend beyond Route 3 and the property is $1.5 \mathrm{ft}$ higher then Route 3, yet it shows the boundary does not extend beyond Route 3.

- On panel 15, a new road named Percy Road was built connecting Route 3 near Hog Back to the intersection with Egan Road.

- On panel 15, along Bog Brook, there are new large bridges built by the State near BFE 1065', 1033', 975', and 895' (at RM3 near the end of Spur Road where it intersects with Bog Road). For about 2,000 ft from BFE 1027' to the end of the road crossing Bog Brook on the northeast side of the panel, there are new developments and roads, private camps, and another small culvert bridge at the intersection of Percy Road and Egan Road.

- On panel 15, there is a 2 mi reach of Bog Brook from Zone A15 to the confluence of East Branch Bog Brook that has the following changes: (1) At Potato Hill Road there are two, private bridges built over the East Branch Bog Brook near BFE 950'. This stream is regulated by the State; (2) Zone A including the wetlands south to Bog Road may be gone because there is no swamp or pond in the area anymore; (3) The dirt access road just south of 926 is called Martha's Way; (4) Old U.S. Route 3 is called Bog Road; (5) the new road connecting Old U.S. Route 3 to Spur Road is called Hollow Road; and (6) the unnamed road at BFE 866' is called Maidstone Road. It is southeast of Route 3 and will connect Bog Road to Spur Road.

- On panel 20, the Nash Street Dam went out and may have changed the Zone A in this area. Main roads do not show up on flood map and the only development is at camps that are leased.

- The town does not have GIS capabilities, no maps are available in electronic format.

- The town does have E-911.

Contact: Steve Allen, Emergency Management Director and Selectman and Patty Summers, Assistant to the Selectmen (922-5533).

\section{Whitefield}

The following provides a summary of the key issues identified during the community interview (October 7, 2005):

- On panel 10, there are some residential structures off of Water Street and off of Union Street that cross the Johns River that may be in the flood zone.

- The town does have GIS capabilities and has maps for wetlands, land use, lowlands, and center lines of the streets.

- The town does has E-911 but not in electronic format.

- Cardiographics, Inc., in Littleton, N.H., does the tax map as a GIS product.

Contact: Judy Ramdell, Secretary to the Board of Selectmen (837-2551) and Bill Thompson, Water Superintendent (837-9237). 


\section{Available Digital Mapping and Remotely Sensed Data}

This section provides an inventory of the digital data available to support the production of DFIRMs for the study area. Basic information is provided on the content, lineage, and accuracy of the products.

\section{Data-Collection Efforts}

To determine the availability of digitally available data, the USGS contacted Lynn Bjorklund (New England Liaison to USGS National Mapping), Fay Rubin (GIS Manager, NH GRANIT, UNH Complex Systems Research Center), North Country Council Regional Planning Commission (NCCouncil), and the communities themselves. The NH GRANIT has useful base mapping.

\section{NH GRANIT Data Sources}

NH GRANIT is a cooperative project to create, maintain, and make available a statewide geographic database serving the information needs of state, regional, and local decision-makers. A collaborative effort between the UNH and the NHOEP, the core GRANIT system is housed at the UNH Institute for the Study of Earth, Oceans, and Space in Durham.

NH GRANIT maintains data layers (http://www.granit.sr.unh.edu) including features such as roads, streams, and political boundaries. Some of the base map data layers maintained by NH GRANIT have been derived from USGS data and represent many of the feature types found on USGS topographic maps. More recently developed data were derived from digital orthophotos providing improved base map accuracy.

NH GRANIT is presently converting the standard, paper FIRMs and Flood Boundary and Floodway maps (FBFMs) to DFIRMs by digitizing existing flood maps from the existing paper flood maps. The DFIRMs will depict flood risk information, and include 100- and 500-year flood plain boundaries as well as areas of minimal flood risk. NH GRANIT is using USGS 1998 DOQs as the base, and they are incorporating any $\mathrm{LOMC}$ that are on file with FEMA.

The Q3 flood-data product is a digital representation of certain features of FEMA's FIRM product and are created by scanning the effective FIRM paper maps and digitizing selected features and lines. The digital Q3 flood data contain the following:

1. 1-percent (100-year) and 0.2-percent (500-year) annual chance flood plain boundaries (including velocity zones),

2. Flood insurance zone designations,

3. Floodway boundaries (where available),

4. Political boundaries (State, county, and community),

5. Community and map panel identification numbers,

6. FIRM panel neatlines,

7. USGS 7.5-minute (1:24,000 scale) series topographic map neatlines, and

8. Coastal Barrier Resources System areas. 


\section{Community Data Resources}

The USGS and NH GRANIT do not have digital base mapping data for Coos County that meet FEMA requirements for DFIRM production. Community data requests were limited to topographic data suitable for hydraulic modeling (for example, 4-ft contours).

Coos County has high resolution digital orthophotos $(1: 12,000)$. No suitable sources of digital elevation data for FEMA flood mapping were located.

\section{Stream Final Coverage Output}

The WISE Scoping Tool organizes and stores data and assists in the prioritization of the community requests for flood plain studies. As the scoping process is completed, three coverages (maps) are created: Effective, Meeting, and Stream Final.

- Effective Coverage: Q3 flood-hazard data are not available for Coos County. NH GRANIT has a contract with FEMA to digitize the FIRMs and they made these nearly completed DFIRMs available to the USGS for purposes of scoping. The DFIRM data for Coos County were received from NH GRANIT on October 15, 2005, although it had not been Quality Assurance/Quality Control checked at that time. Users of the WISE tool should obtain an updated version of the DFIRM data when it becomes available in December of 2006. The DFIRM information was entered into the WISE scoping tool. The initial Scoping Tool database was set up using the U.S. Environmental Protection Agency (USEPA) National Hydrography Dataset (NHD) stream centerline coverage (http://nhd.usgs.gov/data.html) and digital flood boundary base mapping data provided by NH GRANIT. The NHD stream centerline coverage was used to build the Effective Coverage in the Scoping Tool. The digitized flood-hazard data were overlain onto the NHD stream centerline coverage. The Scoping Tool was used to enter each reach of the Effective Coverage one at a time by assigning the beginning and end of each reach and the current effective type of study.

- Meeting Coverage: The Effective Coverage was used to prepare the work maps for recording mapping needs requested by the communities during the Scoping Meetings. These requests were also recorded in the Meeting Coverage of the Scoping Tool.

- Stream Final Coverage: The WISE Scoping Tool was used to create a Stream Final Coverage to document and highlight community meeting results. Community mapping needs based on community input are summarized in figure 4. 


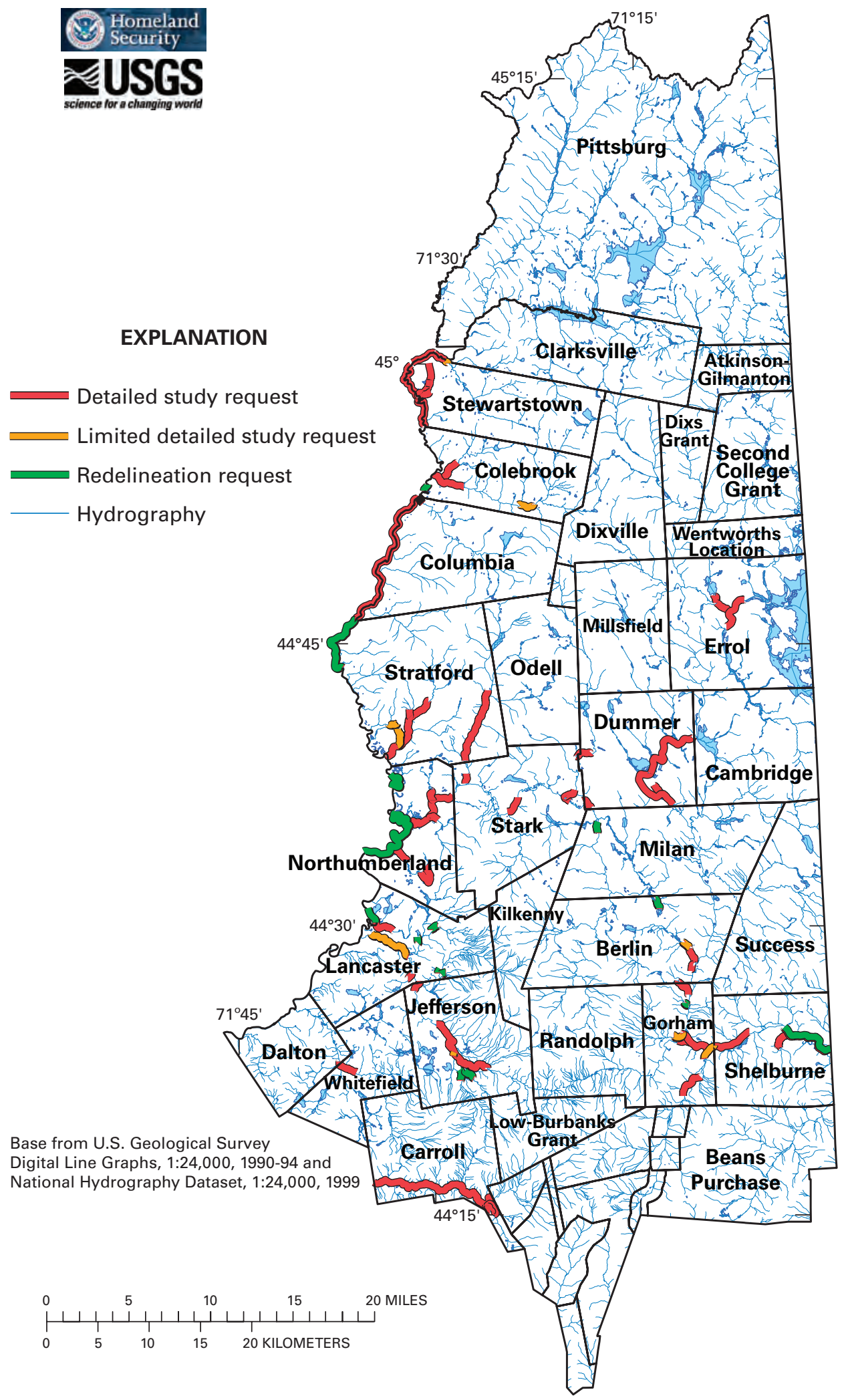

Figure 4. Coos County, New Hampshire, stream final coverage. 


\section{Section 3. Options for Future Mapping and Digital Terrain Model Preparation}

\section{Mapping Requirements}

This section provides an assessment of the costs and benefits of utilizing the data cataloged in the previous section for the preparation of DFIRMs for Coos County. Options are presented for using these data sets in various combinations and supplementing them with new data sets.

DFIRMs are produced from the following three broad categories of geospatial data: (1) Base Map, (2) Digital Terrain Model (DTM), and (3) Flood Insurance Risk Zones. The spatial accuracy of each of these three categories is fixed by the specifications contained in the "Guidelines and Specifications for Flood Hazard Mapping Partners,” April 2003 (Federal Emergency Management Agency, 2004).

- Base Maps: Base maps (1998 DOQs) are being acquired from NH GRANIT and will be used by FEMA as the background to the flood insurance risk zones shown on the DFIRMs.

- DTMs: DTMs are used in conjunction with H\&H models to interpret the limits of flood insurance risk zones.

- Flood Insurance Risk Zones: Geographic boundaries produced by FEMA.

\section{Base Map}

Base maps are defined in the "Guidelines and Specifications" as the "map of the community that depicts cultural features (for example, roads, railroad, bridges, dams, and culverts), drainage features, and corporate limits." Depending on the source of the base map, the specific features found on DFIRMs may include the following data and features:

- Roads: centerlines, edge-of-pavement, right-of-way, names.

- Railroads: names.

- Bridges: names.

- Flood Control Structures: headwall, dam, levee, names.

- Airport Boundaries: names.

- Rivers: centerlines, banks, names.

- Streams: names.

- Lakes: names.

- Political Boundaries: county, municipality, special districts, wards, military reservations, Native American lands, names.

- Land Use: parks, individual land parcels, names.

The "Guidelines and Specifications" specify "absolute horizontal accuracy" for base map features to establish horizontal accuracy for the position of the digital data set to its actual location on the earth's surface. The horizontal accuracy is specified as a statistical error distribution at the 95-percent confidence level and is specified in the "Guidelines and Specifications" as a function of finished map scale, as shown in table 4: 
Table 4. FIRM Horizontal Accuracy.

[FIRM, Flood Insurance Rate Map]

\begin{tabular}{lc}
\hline FIRM map scale & $\begin{array}{c}\text { Absolute horizontal accuracy at } \\
\text { the 95-percent confidence level, } \\
\text { in feet }\end{array}$ \\
\hline 1 in $=500 \mathrm{ft}$ & 19.0 \\
1 in $=1,000 \mathrm{ft}$ & 38.0 \\
1 in $=2,000 \mathrm{ft}$ & 45.6 \\
\hline
\end{tabular}

\section{Digital Terrain Models}

FEMA typically develops DTMs for the production of DFIRMS as they are not widely available at the accuracies required by FEMA. The DTMs are used in conjunction with H\&H models to interpret flood boundaries and can be used by the community for many purposes other than flood management. DTMs represent terrain with irregularly spaced spot elevations $(\mathrm{x}, \mathrm{y}, \mathrm{z})$ and breaklines that indicate changes in ground slope at features such as the toe or top of channel banks or ridge lines. These data sets are generally photogrametrically compiled by a mapping contractor from stereo photos and utilized in the form of a Triangulated Irregular Network (TIN) or a DEM. A DEM uses a regular grid, or raster, spacing of $(\mathrm{x}, \mathrm{y}, \mathrm{z})$ points to represent the land surface. Each grid cell is assigned an average elevation to represent the elevation of the ground that is covered by the grid cell. A DEM represents the terrain surface with a mesh of regularly spaced points, whereas a TIN uses contiguous triangular planes.

Federal Emergency Management Agency (2004) "Guidelines and Specifications" identify the following four types of DTMs: (1) Digital contours, (2) DEMs, (3) Mass points and breaklines, and (4) TIN. Each of these models can be created from the other and their use is application dependent.

Under FEMA guidelines, the allowable DTMs are as follows:

1. Digital contours: continuous, nonintersecting lines of equal elevation separated by a specified elevation interval.

2. DEM: $\mathrm{x}, \mathrm{y}$, and $\mathrm{z}$ coordinates of regularly spaced points that form a grid.

3. Mass Points and Breaklines: $\mathrm{x}, \mathrm{y}$, and $\mathrm{z}$ coordinates of irregularly spaced points.

4. TIN: contiguous triangles with $\mathrm{x}, \mathrm{y}$, and $\mathrm{z}$ values at the vertices and faces with slope and aspect.

The "Guidelines and Specifications" specify what is referred to as "absolute vertical accuracy" for DTMs, which relates the elevation of the land surface in the digital data set to its actual elevation relative to a specific vertical datum. The National Standard for Spatial Data Accuracy (NSSDA) is specified as a statistical error distribution at the 90- and 95-percent confidence level as a function of the specified contour interval as shown in table 5 .

Table 5. National Standard for Spatial Data Accuracy.

[NSSDA, National Standard for Spatial Data Accuracy, all values are in feet]

\begin{tabular}{ccc}
\hline Contour interval & $\begin{array}{c}\text { NSSDA } \\
\text { 90-percent confidence interval }\end{array}$ & $\begin{array}{c}\text { NSSDA } \\
\text { 95-percent confidence interval }\end{array}$ \\
\hline 2 & 1 & 1.2 \\
4 & 2 & 2.4 \\
\hline
\end{tabular}


Contouring and DEMs are not printed on DFIRMS so their vertical accuracy is not labeled on the DFIRMS, but it is recorded in the metadata of elevation datasets used for $\mathrm{H} \& \mathrm{H}$ modeling.

\section{Flood Insurance RiskZones}

Flood insurance risk zones are created by FEMA to set insurance rates and manage the flood plain. Flood insurance risk zone accuracy requirements are not specified in the Guidelines and Specifications but can be described in terms of the combined accuracies of the base map, DTM, and the hydrology and hydraulic simulation models.

\section{Suitability of the Available Data}

The following section provides a summary of the suitability of the base map and DTM available for Coos County, N.H., from the appropriate community, county, and state resources.

\section{USGS of GRANIT}

The USGS and NH GRANIT can provide digital data base mapping data for Coos County that meets FEMA requirements for DFIRM production. Neither USGS nor NH GRANIT has elevation data suitable for hydraulic modeling and communities were contacted to find topographic or elevation data suitable for hydraulic modeling (for example, 2-ft or 4-ft contours).

\section{Community Data Resources}

No community sources of digital elevation data for hydraulic modeling or FEMA flood mapping were located.

\section{County Data Resources}

Coos County does not have suitable data for DFIRM use. Towns in Coos County are within the planning area of the North Country Council, Inc., Regional Planning Commission. The planning commission did not have suitable data for DFIRM use.

\section{Base Map}

NH GRANIT maintains data layers including features such as roads, streams, and political boundaries. Base map layers maintained by NH GRANIT include features such as roads, streams, and political boundaries. Base map data layers have been acquired from a variety of sources including the USGS data and represent many of the feature types found on USGS topographic maps. More recently developed data were derived from the digital orthophotos providing improved base map accuracy.

There are two base map sources available (table 6). These include the USGS DOQs (1:12,000; 1998, 1992) and NAIP Aerial Photographs (1:40,000; 2003). Existing coverages maintained by NH GRANIT can be linked to or viewed at the following Web site: http://www.granit.sr.unh.edu 
Table 6. Currently available high resolution orthophotography for Coos County.

[USGS, U.S. Geological Survey; DOQQ, Digital Orthophoto Quarter Quad; B\&W, Black and White; NAIP, National Agricultural Imagery Program, NH GRANIT, New Hampshire Geographically Referenced Analysis and Information Transfer System]

\begin{tabular}{lllll}
\hline \multicolumn{1}{c}{ Item } & \multicolumn{1}{c}{ Source } & Date & Resolution & Coverage \\
\hline USGS DOQQ B\&W & USGS & 1998,1992 & 1.0 meter pixel & Statewide \\
NAIP 2003 Color & NH GRANIT, NAIP & 2003 & 1.0 meter pixel & Statewide \\
\hline
\end{tabular}

USGS Digital Ortho Quarter Quads (DOQQs) are available for all of Coos County. The DOQQs are FEMA's default standard for the base map. The accuracy and quality of the DOQQs meets National Map Accuracy Standards at 1:12,000 scale for 3.75-minute quarter quadrangles, plus or minus $33.33 \mathrm{ft}$ or $10 \mathrm{~m}$. For Coos County, the DOQQ orthophotos are dated 1998 and are 1.0-m resolution.

The NAIP 2003 color orthophotos were created by the Aerial Photography Field Office (APFO) of the U.S. Department of Agriculture (USDA) and processed by NH GRANIT to (1) standardize the exterior "nodata" values; (2) re-project the data into New Hampshire State Plane Feet (North American Datum of 1983 (NAD 83)); (3) tile the data to 15-minute quadrangles to facilitate distribution; and (4) re-compress the data to MrSID Generation 3 format. The source product is 1-m ground sample distance (GSD) DOQQs from the National Digital Ortho Program (NDOP). The imagery may contain as much as 10-percent cloud cover per source photograph.

\section{Digital Terrain Model}

NH GRANIT has the DEM USGS National Elevation Dataset (NED) available for download. NH GRANIT extracted the NED and re-projected the files into NAD 83. The data are based on USGS 7.5 minute DEMs (30 m x 30 m square grids). The DEMs were derived from USGS 1:24000 and 1:25000 quadrangle maps.

Flood Insurance Risk Zones

FEMA flood insurance rate 100- and 500-year flood zones are being converted to digital data layers by NH GRANIT for each community participating in the NFIP in New Hampshire. These datasets were developed by direct digitization of FIRM maps using data registration techniques that produced the best-fit registration to community boundaries or other suitable features.

\section{Mapping Options}

The following section provides a summary of the potential options for developing base maps, DTMs, and flood insurance risk zones.

\section{Base Map}

Three base map options are presented for consideration:

1. Use existing USGS DOQQs from 1998 and 1992.

2. Use NAIP 2003, 1.0-m resolution color orthophotos.

3. Produce new vector data.

The recommended option for DFIRM production in Coos County is option \#1. 


\section{Digital Terrain Model}

There are no DTM data available that meet FEMA requirements for Coos County.

DTM development options include (1) obtaining countywide DTM data that covers all communities and (2) obtaining DTM data only for selected flood plain areas as needed to support a detailed study, limited detailed study, restudy or re-delineation of flood-hazard areas.

The estimated costs of obtaining new DTM data is shown in table 7. These costs are based on the information determined by Camp, Dresser, and McKee, Inc. (2004) in their 2005 Scoping Report for Rutland County, Vermont. The estimates include the cost of the LiDAR (Light Detection and Ranging) imaging system work and the associated aerial photography work needed to create break line data.

Table 7. Estimate of costs to obtain Digital Terrain Model data (2-ft contours).

\begin{tabular}{ccr}
\hline $\begin{array}{c}\text { Area } \\
\text { (square miles) }\end{array}$ & $\begin{array}{c}\text { Unit cost } \\
\text { (\$ per square mile) }\end{array}$ & Estimated cost \\
\hline 20 & 5,000 & $\$ 100,000$ \\
50 & 3,000 & $\$ 150,000$ \\
75 & 2,250 & $\$ 168,750$ \\
100 & 2,000 & $\$ 200,000$ \\
1,800 & 1,000 & $\$ 1,800,000$ \\
\hline
\end{tabular}

Obtaining DTM data on a countywide basis is expensive. Most of the acquired data would be outside of the flood plain and not needed for hydraulic analysis. If FEMA obtains new DTM data for selected areas as needed, it would be most cost effective to consolidate areas, where possible, and optimize flights, to reduce the unit costs.

\section{Flood Insurance Risk Zones}

The response from communities in Coos County, New Hampshire was mixed regarding the accuracy of the flood insurance risk zones as shown on the existing panels. The most common comment by community representatives was that a better base map is needed to allow easier determination of where the risk zone boundaries are relative to the existing features such as roads and buildings. 


\section{Section 4. Hydrologic and Hydraulic Restudy Needs and Prioritization}

This section summarizes the mapping needs prioritization process and presents the prioritization results based on community input as well as data obtained from other sources including MNUSS and LOMCs.

\section{Mapping Needs}

Based on community input, mapping needs included comments that no new studies were needed, flood plain boundaries are delineated incorrectly, the existing detailed study area needs to be extended, and remapping is needed.

\section{Prioritization Process}

DFIRM data are available for parts of Coos County; however, the DFIRM data received on January 24, 2006, and entered into WISE, has not been Quality Assurance/Quality Control checked.

The data collected from the state and community meetings and MNUSS was entered into the WISE scoping tool. The data then were exported out of WISE and put into a spreadsheet to score each stream segment based on the relative importance of the following factors:

- Community population density.

- Population change (growth).

- Age of effective flood insurance study.

- Significant areas (as defined by the community).

- Existing or proposed development since the FIS.

- Presence of LOMAs/LOMRs.

- Priority (as assigned by community).

- Ranking of importance within the community (community defined).

The prioritization of the flooding sources was based on a number of factors specific to Coos County and is shown in table 8 . 
Table 8. Community flooding source prioritization.

[FIS, Flood Insurance Study; LOMCs, Letters of Map Changes]

\begin{tabular}{|c|c|c|c|c|c|}
\hline \multicolumn{2}{|c|}{$\begin{array}{l}\text { Community population density } \\
\text { (population per square mile) }\end{array}$} & \multicolumn{2}{|c|}{ 1990-2000 percent population growth } & \multicolumn{2}{|c|}{ Year since most recent FIS } \\
\hline Range & Value & Range & Value & Range & Value \\
\hline$>1,000$ & 10 & $>50$ & 10 & $<1980$ & 10 \\
\hline 90-999 & 8 & $40-49$ & 8 & 1980-1984 & 8 \\
\hline $80-89$ & 6 & $30-39$ & 6 & 1985-1989 & 6 \\
\hline $60-79$ & 4 & $20-29$ & 4 & 1990-1994 & 4 \\
\hline $30-59$ & 2 & $10-19$ & 2 & 1995-1999 & 2 \\
\hline $10-29$ & 1 & $5-9$ & 1 & 2000-2004 & 1 \\
\hline$<9$ & 0 & $<4$ & 0 & 2005 & 0 \\
\hline \multicolumn{2}{|c|}{$\begin{array}{c}\text { Significant areas } \\
\text { (as defined by the community) }\end{array}$} & \multicolumn{2}{|c|}{$\begin{array}{l}\text { Existing or proposed development } \\
\text { since FIS }\end{array}$} & \multicolumn{2}{|c|}{ Presence of LOMCs } \\
\hline Range & Value & Range & Value & Range & Value \\
\hline Yes & 5 & Yes & 5 & Yes & 5 \\
\hline No & 0 & No & 0 & No & 0 \\
\hline \multicolumn{2}{|c|}{ Community priority } & \multicolumn{2}{|c|}{ Community ranking } & & \\
\hline Range & Value & Range & Value & & \\
\hline High & 20 & 1 & 10 & & \\
\hline Medium & 10 & 2 & 8 & & \\
\hline \multirow[t]{2}{*}{ Low } & 0 & 3 & 6 & & \\
\hline & & $>4$ & 4 & & \\
\hline
\end{tabular}

\section{Prioritization Results}

The sum of the score for the parameters listed in table 8 was used to determine the final score for each stream and flooding source. The list of prioritized flooding sources is provided in appendix D.

\section{Non-Participating Communities}

The Towns of Randolph, Pittsburg, and Clarksville are not currently in the NFIP. However, community representatives for each of these towns stated that there are no flooding sources of concern. 


\section{Section 5. Recommendations and Schedule}

This section presents flood-mapping recommendations to meet the mapping needs described in previous sections.

\section{Mapping Recommendations}

FEMA's goal is to develop updated DFIRMs and FISs for Coos County, New Hampshire. The County has a total area of approximately $1,831 \mathrm{mi}^{2}$ of which $1,800 \mathrm{mi}^{2}$ is land and $31 \mathrm{mi}^{2}$ is water. Coos County encompasses 21 incorporated cities and towns and 22 unincorporated locations, grants, townships or purchases.

\section{Mapping Options}

Mapping can be categorized based on the level of detail and required study effort to create or update flood-hazard zones.

- Baseline-DFIRM only: The most economical method of creating a countywide DFIRM is through digitizing flood-hazard information from the effective FIRMs and FISs onto new mapping. This baseline option is currently being undertaken by NH GRANIT.

- Redelineation: Detailed topography (2-ft contour interval) is not currently available. The floodhazard information from the effective FIRMs and FISs can be redelineated onto new topography and base mapping as it becomes available.

- Limited Detailed Study: Automated tools are used to produce digital information. This assumes new field surveys for structures but, no new field surveys for cross-sections are needed and that the existing hydraulic model can be used.

- Detailed Study: Can be performed to develop the digital information, including field surveyed cross-sections and structures. Since this is the most expensive type of study that FEMA can perform, the extent of the detailed study may be limited.

\section{Project Alternatives}

Costs can be reduced by cutting back on the level of effort for the H\&H analyses and(or) reducing the number of DFIRM panels. Alternative H\&H options that would help FEMA to reduce costs include reducing the study scope from a detailed study to a limited detail study or redelineation of current flood information only. Reducing the number of DFIRM panels by altering the mix of panel scales would lower the total panel count and reduce the estimated DFIRM production cost.

\section{Schedule}

The project schedule will vary depending on the final scope of the work. Detailed and Limited Detail Restudy and DFIRM production can be completed in 24 months, plus the time required for post preliminary processing, which may be completed in about 6 months for a total of 30 months. 


\section{Selected References}

Camp, Dresser, and McKee, Inc., 2004, Flood insurance study needs in the Blackstone River basin in Providence County, Rhode Island and Worcester County, Massachusetts: Contract No. EME-2003-CO-0340, Task Order T001, Task 1, February 2004, variously paged.

Camp, Dresser, and McKee, Inc., 2005, Flood insurance study needs in Rutland County, Vermont: Contract No. EME-2003-CO-0340, variously paged.

Federal Emergency Management Agency, 2004, Guidelines and specifications for flood-hazard mapping partners, accessed online January 10, 2006, at http://www.fema.gov/plan/prevent/fhm/gs_main.shtm

New Hampshire GRANIT (Geographically Referenced ANalysis and Information Transfer system), 2006, accessed online January 12, 2006, at http://www.granit.sr.unh.edu/

University of New Hampshire, 2005, Carsey Institute, accessed online September 28, 2005, at http://www.nneindicators.unh.edu/ShowOneRegion.asp?IndicatorID=1\&FIPS=33013.

Watershed Concepts, a Division of Hayes, Seay, Mattern and Mattern, Watershed Information System (WISE), version 2.0.9, 2005. 


\section{Appendix A. Summary of Letters of Map Change (LOMC) Data in Coos County}


Table A-1. Summary of LOMC data in Coos County.

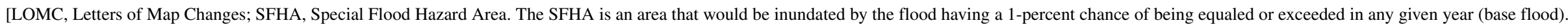
LOMA, Letter of Map Amendment; LOMR-FW, Letter of Map Revision Floodway; LOMA-OAS, Letter of Map Amendment Out-As-Show; LOMR-F, Letter of Map Revision based on Fill; --, no data]

\begin{tabular}{|c|c|c|c|c|c|c|c|c|c|c|}
\hline Community & LOMC type & $\begin{array}{c}\text { Case } \\
\text { number }\end{array}$ & $\begin{array}{l}\text { Effective } \\
\text { date }\end{array}$ & Flooding source & Address & $\begin{array}{l}\text { Property } \\
\text { latitude }\end{array}$ & $\begin{array}{c}\text { Property } \\
\text { longi- } \\
\text { tude }\end{array}$ & $\begin{array}{l}\text { Removed from } \\
\text { SFHA (1) }\end{array}$ & $\begin{array}{l}\text { New } \\
\text { flood } \\
\text { zone }\end{array}$ & Notes \\
\hline Colebrook, N.H. & LOMA & $05-01-0312 \mathrm{~A}$ & $4 / 28 / 2005$ & Mohawk River & $\begin{array}{l}\text { Colebrook Golf } \\
\text { Course }\end{array}$ & 44.895 & -71.488 & Portion of property & $\mathrm{C}$ & Portions remain in the SFHA; Zone A. \\
\hline Colebrook, N.H. & LOMA-OAS & 01-01-0734A & $5 / 2 / 2001$ & Mohawk River & 8 Parsons Street & 44.893 & -71.496 & Office and showroom & $\mathrm{X}$ & Portions remain in the SFHA; Zone A. \\
\hline Colebrook, N.H. & LOMA & 00-01-0148A & $3 / 17 / 2000$ & Mohawk River & RFD \#1, Box 103 & 44.872 & -71.385 & Structures & $\mathrm{X}$ & Portions remain in the SFHA. \\
\hline Gorham, N.H. & LOMR-F & 00-01-1000A & $10 / 12 / 2000$ & Peabody River & 2 Underhill Street & 44.384 & -71.168 & Structure & $\mathrm{AE}$ & Source of base flood elevation. \\
\hline Gorham, N.H. & LOMA & $99-01-1288 \mathrm{~A}$ & $12 / 29 / 1999$ & Peabody River & 48 Bangor Street & 44.384 & -71.168 & Residential structure & $\mathrm{X}$ & Portions remain in the SFHA. \\
\hline Gorham, N.H. & LOMR & 99-01-017P & $12 / 1 / 1999$ & Peabody River & -- & -- & -- & -- & $\mathrm{AE}$ & -- \\
\hline Lancaster, N.H. & LOMA & $03-01-2062 \mathrm{~A}$ & $11 / 6 / 2003$ & Connecticut River & 22 Stockwell Road & 44.507 & -71.571 & Residential structure & $\mathrm{C}$ & Portions remain in the SFHA. \\
\hline Shelburne, N.H. & LOMA & $99-01-166 \mathrm{~A}$ & 3/12/1999 & Androscoggin River & 1333 State Route 2 & 44.395 & -71.048 & Residential structure & $\mathrm{C}$ & Portions remain in the SFHA. \\
\hline Stewartstown, N.H. & LOMA & 05-01-0621A & $7 / 12 / 2005$ & Connecticut River & 18 River Road & 45.008 & -71.506 & Residential structure & $\mathrm{C}$ & Portions remain in the SFHA; Zone A. \\
\hline Stratford, N.H. & LOMA-OAS & 04-01-1488A & $9 / 2 / 2004$ & Bog Brook & $\begin{array}{l}\text { R.R. \#1, Box 584, } \\
\text { Spur Road }\end{array}$ & 44.651 & -71.556 & Reidential structure & $\mathrm{C}$ & Portions remain in the floodway. \\
\hline Stratford, N.H. & LOMA & 00-01-0946A & $9 / 12 / 2000$ & Bog Brook & Bog Road & 44.675 & -71.538 & Residential structure & A3 & Source of base flood elevation. \\
\hline Stratford, N.H. & LOMA & 01-01-0424A & $2 / 9 / 2001$ & Bog Brook & Bog Road & 44.675 & -71.538 & Residential structure & A3 & $\begin{array}{l}\text { Source of base flood elevation. Super- } \\
\text { cedes previous determination. }\end{array}$ \\
\hline
\end{tabular}




\title{
Appendix B. Mapping Needs Update Support System (MNUSS) Needs Assessment Reports
}

\author{
Coos County, New Hampshire \\ MNUSS Needs Assessment Reports Summary Table
}

New Hampshire Mapping Needs in MNUSS

April 19, 2006 
Table B-1. Mapping Needs Update Support System (MNUSS) needs assessment reports summary.

\begin{tabular}{|c|c|c|c|c|c|c|c|}
\hline \multirow[b]{2}{*}{ CID } & \multirow[b]{2}{*}{ Community name } & \multirow[b]{2}{*}{ County } & \multirow[b]{2}{*}{ Unmapped } & \multicolumn{4}{|c|}{ Needs } \\
\hline & & & & $\begin{array}{l}\text { Flood data } \\
\text { update* }\end{array}$ & $\begin{array}{c}\text { Map } \\
\text { maintenance* }\end{array}$ & Pending & Resolved \\
\hline 330029 & Berlin, City of & Coos County & & & 1 & 0 & 0 \\
\hline 330030 & Carroll, Town of & Coos County & & & 0 & 0 & 0 \\
\hline 330184 & Clarksville, Town of & Coos County & & & 0 & 0 & 0 \\
\hline 330031 & Colebrook, Town of & Coos County & & & 0 & 0 & 0 \\
\hline \multirow[t]{2}{*}{330185} & Columbia, Town of & Coos County & & & 0 & 0 & 0 \\
\hline & Dalton, Town of & Coos County & & & 0 & 0 & 0 \\
\hline 330200 & Dixville, Town of & Coos County & * & 0 & 0 & 0 & 0 \\
\hline 330201 & Dummer, Town of & Coos County & & & 1 & 0 & 0 \\
\hline 330206 & Errol, Town of & Coos County & & & 0 & 0 & 0 \\
\hline \multirow[t]{2}{*}{330032} & Gorham, Town of & Coos County & & & 0 & 0 & 0 \\
\hline & Jefferson, Town of & Coos County & & & 0 & 0 & 0 \\
\hline 335277 & Lancaster, Town of & Coos County & & & 0 & 0 & 0 \\
\hline 330035 & Milan, Town of & Coos County & & & 0 & 0 & 0 \\
\hline 330223 & Millsfield, Town of & Coos County & * & 0 & 0 & 0 & 0 \\
\hline \multirow[t]{2}{*}{330036} & Northumberland, Town of & Coos County & & & 0 & 0 & 0 \\
\hline & Pittsburg, Town of & Coos County & & & 0 & 0 & 0 \\
\hline 330187 & Randolph, Town of & Coos County & & & 0 & 0 & 0 \\
\hline 330037 & Shelburne, Town of & Coos County & & & 1 & 0 & 0 \\
\hline 330038 & Stark, Town of & Coos County & & & 0 & 0 & 0 \\
\hline 330194 & Stewartstown, Town of & Coos County & & & 0 & 0 & 0 \\
\hline \multirow{3}{*}{330040} & Stratford, Town of & Coos County & & & 0 & 0 & 0 \\
\hline & Whitefield, Town of & Coos County & & & 0 & 0 & 0 \\
\hline & Totals & & & $<0$ & 3 & 0 & 0 \\
\hline
\end{tabular}

*These needs have a status of "Existing" or "Being Addressed". 


\section{Appendix C. State and Community Meetings}




\begin{tabular}{|c|c|c|}
\hline \\
\hline \multicolumn{3}{|c|}{$\begin{array}{l}\text { GENERAL COMMUNITY INFORMATION } \\
\text { Community: } \quad \text { BERLIN, CITY OF }\end{array}$} \\
\hline County: & COOS COUNTY & New Hampshire \\
\hline
\end{tabular}

\begin{tabular}{lcc}
\hline NEED DETAIL INFORMATION & \\
\hline $\begin{array}{l}\text { Need ID: } \\
\text { Source: }\end{array}$ & FE0000000010575 & Entered By: Chuck Wood \\
& & Date: 10/13/1997 \\
& & Approved By: FEMA \\
& & Date: 10/13/1997 \\
\hline Study Category: & RIVERINE & Need Types: Changes to floodplain width \\
Flooding Source: & ANDROSCOGGIN RIVER & \\
\hline Status: & Existing & \\
\hline
\end{tabular}

\section{NEED FLOODPLAIN DATA}

Anticipated BFE Change:

Decreased By Between 1 and 5 feet

Length of Study:

0.35 miles

Average Width of Floodplain:

350 feet

Location of Floodplain:

\section{PANELS AFFECTED BY THE NEED}

3300290017B (06/15/1982)

\begin{tabular}{llll}
\hline ORIGIN OF NEED INFORMATION & & \\
\hline Entity: & BERLIN, CITY OF [FIRE DEPT.] & Phone: & (603) 752-3135 Ext: Unspecified \\
Last Name: & LAVERTUE & First Name: & MAURICE \\
Address 1: & 263 MAIN STREET & Title: & BUILDING INSPECTOR \\
Address 2: & Unspecified & Email: & Unspecified \\
City: & BERLIN & Fax: & Unspecified \\
State: & NH & Zip: & $03570-$
\end{tabular}

\begin{tabular}{|c|c|c|}
\hline \multicolumn{3}{|c|}{ NEED NOTES AND COMMENTS } \\
\hline Date & $\begin{array}{l}\text { Entered } \\
\text { By }\end{array}$ & Note \\
\hline 09/30/2002 & $\begin{array}{l}\text { Kara } \\
\text { Deutsch }\end{array}$ & $\begin{array}{l}\text { Berlin Planning Department stated that Cleveland Bridge } \\
\text { was constructed but is not reflected on the FIRMs. Need } \\
\text { cross-sections and benchmarks in this area. }\end{array}$ \\
\hline
\end{tabular}




\begin{tabular}{|c|c|c|}
\hline \multicolumn{3}{|c|}{ GENERAL COMMUNITY INFORMATION } \\
\hline Community: & BERLIN, CITY OF & CID: 330029 \\
\hline County: & COOS COUNTY & New Hampshire \\
\hline
\end{tabular}

\begin{tabular}{|c|c|c|}
\hline \multicolumn{3}{|c|}{ NEED DETAIL INFORMATION } \\
\hline Need ID: & 100000000029275 & Entered By: Kara Deutsch \\
\hline \multirow[t]{3}{*}{ Source: } & State Implementation Plan & Date: 09/30/2002 \\
\hline & & Approved By: Automatic (no FEMA validation) \\
\hline & & Date: $11 / 14 / 2002$ \\
\hline Study Category: & MAINTENANCE & $\begin{array}{l}\text { Need Types: Add streets to panel } \\
\text { Add an ERM }\end{array}$ \\
\hline Status: & Existing & \\
\hline
\end{tabular}

\section{PANELS AFFECTED BY THE NEED}

$\begin{array}{ll}3300290004 \mathrm{~B}(06 / 15 / 1982) & 3300290005 \mathrm{~B}(06 / 15 / 1982) \\ 3300290006 \mathrm{~B}(06 / 15 / 1982) & 3300290010 \mathrm{~B}(06 / 15 / 1982) \\ 3300290011 \mathrm{~B}(06 / 15 / 1982) & 3300290012 \mathrm{~B}(06 / 15 / 1982) \\ 3300290016 \mathrm{~B}(06 / 15 / 1982) & 3300290017 \mathrm{~B}(06 / 15 / 1982)\end{array}$

\begin{tabular}{llll}
\hline ORIGIN OF NEED INFORMATION & & \\
\hline Entity: & BERLIN PLANNING DEPARTMENT & Phone: & (603) 752-1630 Ext: Unspecified \\
Last Name: & LAFLAMME & First Name: & PAMELA \\
Address 1: & 168 MAIN STREET & Title: & CITY PLANNER \\
Address 2: & Unspecified & Email: & planning@ncia.net \\
City: & BERLIN & Fax: & $(603) 752-8553$ \\
State: & NH & Zip: & 03570
\end{tabular}

\section{NEED NOTES AND COMMENTS}

There are no notes for this need. 


\begin{tabular}{|c|c|c|}
\hline \multicolumn{3}{|c|}{ GENERAL COMMUNITY INFORMATION } \\
\hline Community: & BERLIN, CITY OF & CID: 330029 \\
\hline County: & COOS COUNTY & New Hampshire \\
\hline
\end{tabular}

\begin{tabular}{|c|c|c|}
\hline \multicolumn{3}{|c|}{ NEED DETAIL INFORMATION } \\
\hline Need ID: & 100000000029276 & Entered By: Kara Deutsch \\
\hline \multirow[t]{3}{*}{ Source: } & State Implementation Plan & Date: 09/30/2002 \\
\hline & & Approved By: Automatic (no FEMA validation) \\
\hline & & Date: $11 / 14 / 2002$ \\
\hline Study Category: & RIVERINE & $\begin{array}{c}\text { Need Types: Changes to hydrologic conditions } \\
\text { Changes to hydraulic analysis } \\
\text { Changes to floodplain width }\end{array}$ \\
\hline Flooding Source: & DEAD RIVER & \\
\hline Status: & Existing & \\
\hline
\end{tabular}

\section{NEED FLOODPLAIN DATA}

Anticipated BFE

Change:

Increased By Less Than 1 foot

Length of Study:

0.3 miles

Average Width of

Floodplain:

Location of

80 feet

from Pleasant Street to confluence with Androscoggin River Floodplain:

\section{PANELS AFFECTED BY THE NEED}

$3300290017 \mathrm{~B}(06 / 15 / 1982)$

\begin{tabular}{llll}
\hline ORIGIN OF NEED INFORMATION & & \\
\hline Entity: & BERLIN PLANNING DEPARTMENT & Phone: & $(603) 752-1630$ Ext: Unspecified \\
Last Name: & LAFLAMME & First Name: & PAMELA \\
Address 1: & 168 MAIN STREET & Title: & CITY PLANNER \\
Address 2: & Unspecified & Email: & planning@ncia.net \\
City: & BERLIN & Fax: & $(603) 752-8553$ \\
State: & NH & Zip: & 03570
\end{tabular}

\section{NEED NOTES AND COMMENTS}

\section{Date Entered By Note}

09/30/2002 Kara Deutsch Growth in area, as well as erosion and flooding issues. 


\begin{tabular}{|c|c|c|c|}
\hline \multicolumn{4}{|c|}{ GENERAL COMMUNITY INFORMATION } \\
\hline Community: & COLEBROOK, TOWN OF & & 330031 \\
\hline County: & coOS COUNTY & State: & New Hampshire \\
\hline
\end{tabular}

\begin{tabular}{|c|c|c|}
\hline \multicolumn{3}{|c|}{ NEED DETAIL INFORMATION } \\
\hline Need ID: & 100000000010614 & Entered By: Chuck Wood \\
\hline \multirow[t]{3}{*}{ Source: } & FEMA 5-year letter & Date: 04/01/1998 \\
\hline & & Approved By: FEMA \\
\hline & & Date: $4 / 1 / 1998$ \\
\hline Study Category: & RIVERINE & Need Types: Changes to hydraulic analysis \\
\hline Flooding Source: & CONNECTICUT RIVER & \\
\hline Status: & Existing & \\
\hline
\end{tabular}

\begin{tabular}{ll}
\hline NEED FLOODPLAIN DATA & \\
\hline Anticipated BFE Change: & Decreased By Less Than 1 foot \\
Length of Study: & 5.85 miles \\
Average Width of Floodplain: & 170 feet \\
Location of Floodplain: &
\end{tabular}

\section{PANELS AFFECTED BY THE NEED}

3300310010B (05/17/1989)

\begin{tabular}{|c|c|c|c|}
\hline \multicolumn{4}{|c|}{ ORIGIN OF NEED INFORMATION } \\
\hline Entity: & $\begin{array}{l}\text { COLEBROOK, TOWN OF [TOWN } \\
\text { GOVERNMENT] }\end{array}$ & Phone: & 6032375200 Ext: Unspecified \\
\hline $\begin{array}{l}\text { Last } \\
\text { Name: }\end{array}$ & MILLER & $\begin{array}{l}\text { First } \\
\text { Name: }\end{array}$ & FRED \\
\hline Address 1: & 10 BRIDGE STREET & Title: & CONTACT PERSON \\
\hline Address 2: & Unspecified & Email: & Unspecified \\
\hline City: & COLEBROOK & Fax: & 6032375069 \\
\hline State: & $\mathrm{NH}$ & Zip: & 03576- \\
\hline
\end{tabular}

\begin{tabular}{lll}
\hline \multicolumn{2}{l}{ NEED NOTES AND COMMENTS } \\
\hline Date $\quad \begin{array}{ll}\text { Entered } \\
\text { By }\end{array}$ & Note \\
04/01/1998 $\begin{array}{l}\text { Chuck } \\
\text { Wood }\end{array}$ & THE COMMUNITY STATES THAT A DAM HAS BEEN \\
& ADDED ALONG THIS RIVER \\
04/01/1998 $\begin{array}{l}\text { Chuck } \\
\text { Wood }\end{array}$ & THE COMMUNITY STATES THAT A DAM HAS BEEN \\
& ADDED ALONG THIS RIVER
\end{tabular}




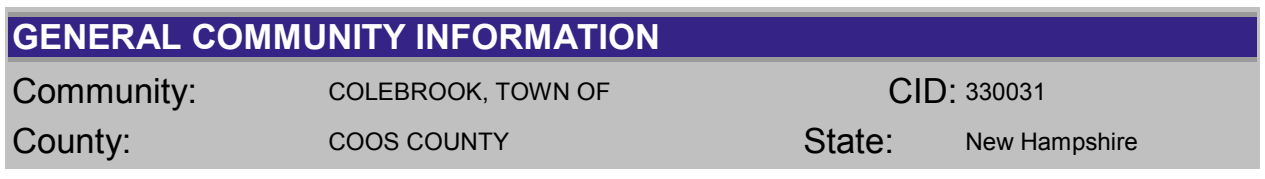

\begin{tabular}{lcc}
\hline NEED DETAIL INFORMATION & \\
\hline $\begin{array}{l}\text { Need ID: } \\
\text { Source: }\end{array}$ & FEMA 5-year letter & Entered By: Chuck Wood \\
& & Date: 04/01/1998 \\
& & Approved By: FEMA \\
& Date: 4/1/1998 \\
\hline $\begin{array}{l}\text { Study Category: } \\
\text { Flooding Source: }\end{array}$ & RIVERINE & Nohawk River \\
\hline Status: & Existing & \\
\hline
\end{tabular}

\begin{tabular}{ll}
\hline NEED FLOODPLAIN DATA & \\
\hline Anticipated BFE Change: & Increased By Greater Than 5 feet \\
Length of Study: & 10.98 miles \\
Average Width of Floodplain: & 400 feet \\
Location of Floodplain: &
\end{tabular}

\section{PANELS AFFECTED BY THE NEED}

3300310005B (05/17/1989)

3300310010B (05/17/1989)

\begin{tabular}{|c|c|c|c|}
\hline \multicolumn{4}{|c|}{ ORIGIN OF NEED INFORMATION } \\
\hline Entity: & $\begin{array}{l}\text { COLEBROOK, TOWN OF [TOWN } \\
\text { GOVERNMENT] }\end{array}$ & Phone: & 6032375200 Ext: Unspecified \\
\hline $\begin{array}{l}\text { Last } \\
\text { Name: }\end{array}$ & MILLER & $\begin{array}{l}\text { First } \\
\text { Name: }\end{array}$ & FRED \\
\hline Address 1: & 10 BRIDGE STREET & Title: & CONTACT PERSON \\
\hline Address 2: & Unspecified & Email: & Unspecified \\
\hline City: & COLEBROOK & Fax: & 6032375069 \\
\hline State: & $\mathrm{NH}$ & Zip: & 03576- \\
\hline
\end{tabular}

\section{NEED NOTES AND COMMENTS}

There are no notes for this need. 


\begin{tabular}{|c|c|c|}
\hline \\
\hline \multicolumn{3}{|c|}{$\begin{array}{l}\text { GENERAL COMMUNITY INFORMATION } \\
\text { Community: } \quad \text { COLEBROOK, TOWN OF }\end{array}$} \\
\hline County: & COOS COUNTY & New Hampshire \\
\hline
\end{tabular}

\begin{tabular}{|c|c|c|}
\hline \multicolumn{3}{|c|}{ NEED DETAIL INFORMATION } \\
\hline Need ID: & 100000000010613 & Entered By: Chuck Wood \\
\hline \multirow[t]{3}{*}{ Source: } & FEMA 5-year letter & Date: 04/01/1998 \\
\hline & & Approved By: FEMA \\
\hline & & Date: $4 / 1 / 1998$ \\
\hline Study Category: & RIVERINE & Need Types: Changes to floodplain width \\
\hline Flooding Source: & \multicolumn{2}{|c|}{ NORTH BR. MOHAWK RIVER } \\
\hline Status: & Existing & \\
\hline
\end{tabular}

\begin{tabular}{ll}
\hline NEED FLOODPLAIN DATA & \\
\hline Anticipated BFE Change: & Increased By Greater Than 5 feet \\
Length of Study: & 3.33 miles \\
Average Width of Floodplain: & 320 feet \\
Location of Floodplain: &
\end{tabular}

\section{PANELS AFFECTED BY THE NEED}

3300310005B (05/17/1989)

\begin{tabular}{|c|c|c|c|}
\hline \multicolumn{4}{|c|}{ ORIGIN OF NEED INFORMATION } \\
\hline Entity: & $\begin{array}{l}\text { COLEBROOK, TOWN OF [TOWN } \\
\text { GOVERNMENT] }\end{array}$ & Phone: & 6032375200 Ext: Unspecified \\
\hline $\begin{array}{l}\text { Last } \\
\text { Name: }\end{array}$ & MILLER & $\begin{array}{l}\text { First } \\
\text { Name: }\end{array}$ & FRED \\
\hline Address 1: & 10 BRIDGE STREET & Title: & CONTACT PERSON \\
\hline Address 2: & Unspecified & Email: & Unspecified \\
\hline City: & COLEBROOK & Fax: & 6032375069 \\
\hline State: & $\mathrm{NH}$ & Zip: & 03576- \\
\hline
\end{tabular}

\section{NEED NOTES AND COMMENTS}

There are no notes for this need. 


\begin{tabular}{lll}
\hline GENERAL COMMUNITY INFORMATION & \\
\hline Community: & COLEBROOK, TOWN OF & CID: 330031 \\
County: & COOS COUNTY & State: $\quad$ New Hampshire
\end{tabular}

\begin{tabular}{|c|c|c|}
\hline \multicolumn{3}{|c|}{ NEED DETAIL INFORMATION } \\
\hline Need ID: & 100000000010611 & Entered By: Chuck Wood \\
\hline \multirow{3}{*}{ Source: } & FEMA 5-year letter & Date: $04 / 01 / 1998$ \\
\hline & & Approved By: FEMA \\
\hline & & Date: $4 / 1 / 1998$ \\
\hline Study Category: & RIVERINE & Need Types: Changes to floodplain width \\
\hline Flooding Source: & WEST \& EAST BRANCH & \\
\hline Status: & Existing & \\
\hline
\end{tabular}

\section{NEED FLOODPLAIN DATA}

Anticipated BFE Change: Increased By Greater Than 5 feet

Length of Study:

7.46 miles

Average Width of Floodplain: $\quad 400$ feet

Location of Floodplain:

\section{PANELS AFFECTED BY THE NEED}

3300310010B (05/17/1989)

\begin{tabular}{|c|c|c|c|}
\hline \multicolumn{4}{|c|}{ ORIGIN OF NEED INFORMATION } \\
\hline Entity: & $\begin{array}{l}\text { COLEBROOK, TOWN OF [TOWN } \\
\text { GOVERNMENT] }\end{array}$ & Phone: & 6032375200 Ext: Unspecified \\
\hline $\begin{array}{l}\text { Last } \\
\text { Name: }\end{array}$ & MILLER & $\begin{array}{l}\text { First } \\
\text { Name: }\end{array}$ & FRED \\
\hline Address 1: & 10 BRIDGE STREET & Title: & CONTACT PERSON \\
\hline Address 2: & Unspecified & Email: & Unspecified \\
\hline City: & COLEBROOK & Fax: & 6032375069 \\
\hline State: & $\mathrm{NH}$ & Zip: & 03576- \\
\hline
\end{tabular}

\section{NEED NOTES AND COMMENTS}

\section{Date Entered By Note}

04/01/1998 Chuck Wood COMMUNITY WANTS A COMPLETE RESTUDY

04/01/1998 Chuck Wood COMMUNITY WANTS A COMPLETE RESTUDY 


\begin{tabular}{|c|c|c|}
\hline \\
\hline Community: & DUMMER, TOWN OF & $\begin{array}{l}\text { GENERAL COMMUNITY INFORMATION } \\
\text { Community. }\end{array}$ \\
\hline County: & COOS COUNTY & New Hampshire \\
\hline
\end{tabular}

\begin{tabular}{lcc} 
NEED DETAIL INFORMATION & \\
$\begin{array}{l}\text { Need ID: } \\
\text { Source: }\end{array}$ & FEMA 5-year letter & $\begin{array}{c}\text { Entered By: Chuck Wood } \\
\end{array}$ \\
& & Date: 10/14/1997 \\
& & Approved By: FEMA \\
& Date: 10/14/1997 \\
\hline $\begin{array}{l}\text { Study Category: } \\
\text { Flooding Source: }\end{array}$ & RIVERINE & ANDROSCOGGIN RIVER \\
& & \\
\hline Status: & Existing & \\
\hline
\end{tabular}

\begin{tabular}{ll}
\hline NEED FLOODPLAIN DATA & \\
\hline Anticipated BFE Change: & Increased By Greater Than 5 feet \\
Length of Study: & 8.3 miles \\
Average Width of Floodplain: & 1500 feet \\
Location of Floodplain: &
\end{tabular}

\section{PANELS AFFECTED BY THE NEED}

3302019999 (03/01/1995)

\begin{tabular}{llll}
\hline \multicolumn{2}{l}{ ORIGIN OF NEED INFORMATION } & & \\
\hline Entity: & TOWN OF DUMMER & Phone: & 6034493464 Ext: Unspecified \\
Last Name: & HANSON & First Name: & LEONARD B. \\
Address 1: & 75 HILL ROAD & Title: & PLANNING BOARD CHAIRMAN \\
Address 2: & Unspecified & Email: & Unspecified \\
City: & DUMMER & Fax: & Unspecified \\
State: & ME & Zip: & $03588-5406$
\end{tabular}

\begin{tabular}{lll}
\hline \multicolumn{2}{l}{ NEED NOTES AND COMMENTS } \\
\hline Date & $\begin{array}{l}\text { Entered } \\
\text { By }\end{array}$ & Note \\
$10 / 14 / 1997$ & Chuck & REVISE RIVER DUE TO NEW STRUCTURES ON THE \\
Wood & FLOODPLAIN. ADD ELEVATIONS. \\
Chuck & REVISE RIVER DUE TO NEW STRUCTURES ON THE \\
10/14/1997 & Wood & FLOODPLAIN. ADD ELEVATIONS.
\end{tabular}




\begin{tabular}{lll}
\hline GENERAL COMMUNITY INFORMATION & \\
\hline Community: & DUMMER, TOWN OF & \multicolumn{2}{c}{ CID: 330201} \\
County: & COOS COUNTY & State: $\quad$ New Hampshire
\end{tabular}

\begin{tabular}{lcc}
\hline NEED DETAIL INFORMATION & \\
\hline $\begin{array}{l}\text { Need ID: } \\
\text { Source: }\end{array}$ & 100000000010576 & $\begin{array}{c}\text { Entered By: Chuck Wood } \\
\text { Date: } 10 / 14 / 1997\end{array}$ \\
& & $\begin{array}{c}\text { Fpproved By: FEMA } \\
\text { Datear letter }\end{array}$ \\
& & No/14/1997 \\
\hline Study Category: & MAINTENANCE & Need Types: Add LOMCs (per panel) \\
\hline Status: & Existing & \\
\hline
\end{tabular}

\section{PANELS AFFECTED BY THE NEED}

$3302019999(03 / 01 / 1995)$

\begin{tabular}{|c|c|c|c|}
\hline \multicolumn{4}{|c|}{ ORIGIN OF NEED INFORMATION } \\
\hline Entity: & TOWN OF DUMMER & Phone: & Ext: Unspecified \\
\hline Last Name: & HANSON & First Name: & LEONARD B. \\
\hline Address 1: & 75 HILL ROAD & Title: & PLANNING BOARD CHAIRMAN \\
\hline Address 2: & Unspecified & Email: & Unspecified \\
\hline City: & DUMMER & Fax: & Unspecified \\
\hline State: & ME & Zip: & $03588-5406$ \\
\hline
\end{tabular}

\section{NEED NOTES AND COMMENTS}

There are no notes for this need. 


\begin{tabular}{lll}
\hline GENERAL COMMUNITY INFORMATION & \\
\hline Community: & ERROL, TOWN OF & \multicolumn{2}{c}{ CID: 330206} \\
County: & COOS COUNTY & State: $\quad$ New Hampshire
\end{tabular}

\begin{tabular}{|c|c|c|}
\hline \multicolumn{3}{|c|}{ NEED DETAIL INFORMATION } \\
\hline Need ID: & 100000000010579 & Entered By: Chuck Wood \\
\hline \multirow[t]{3}{*}{ Source: } & FEMA 5-year letter & Date: $12 / 05 / 1997$ \\
\hline & & Approved By: FEMA \\
\hline & & Date: $12 / 5 / 1997$ \\
\hline Study Category: & RIVERINE & Need Types: Changes to hydrologic conditions \\
\hline Flooding Source: & All Zone A'S & \\
\hline Status: & Existing & \\
\hline
\end{tabular}

\section{NEED FLOODPLAIN DATA}

Anticipated BFE Change: Increased By Greater Than 5 feet

Length of Study:

45.45 miles

Average Width of Floodplain: $\quad 800$ feet

Location of Floodplain:

\section{PANELS AFFECTED BY THE NEED}

No panels have been associated with this need.

\section{ORIGIN OF NEED INFORMATION}

Entity: $\quad$ ERROL, TOWN OF [TOWN GOVERNMENT] Phone: 6034823351 Ext: Unspecified Last Name: ENMAN First Name: LARRY

Address 1: 33 MAIN STREET

Title: SELECTMAN

Address 2: P.O. BOX 100

City: ERROL Fax: 6034823804

State: NH Zip:

\begin{tabular}{|c|c|c|}
\hline \multicolumn{3}{|c|}{ NEED NOTES AND COMMENTS } \\
\hline Date & $\begin{array}{l}\text { Entered } \\
\text { By }\end{array}$ & Note \\
\hline $12 / 05 / 1997$ & $\begin{array}{l}\text { Chuck } \\
\text { Wood }\end{array}$ & $\begin{array}{l}\text { CURRENT } 11 \text { X } 17 \text { MAP WILL HAVE TO BE UPDATED } \\
\text { TO Z-FOLD FORMAT. }\end{array}$ \\
\hline $12 / 05 / 1997$ & $\begin{array}{l}\text { Chuck } \\
\text { Wood }\end{array}$ & $\begin{array}{l}\text { CURRENT } 11 \text { X } 17 \text { MAP WILL HAVE TO BE UPDATED } \\
\text { TO Z-FOLD FORMAT. }\end{array}$ \\
\hline
\end{tabular}




\begin{tabular}{|c|c|c|}
\hline \\
\hline Community: & GORHAM, TOWN OF & $\begin{array}{l}\text { GENERAL COMMUNITY INFORMATION } \\
\text { Community. } \quad \text { GORHAM. TOWN OF }\end{array}$ \\
\hline County: & COOS COUNTY & New Hampshire \\
\hline
\end{tabular}

\begin{tabular}{|c|c|c|}
\hline \multicolumn{3}{|c|}{ NEED DETAIL INFORMATION } \\
\hline Need ID: & 100000000025967 & Entered By: Tim Witt \\
\hline \multirow[t]{3}{*}{ Source: } & Other & Date: 09/29/2001 \\
\hline & & Approved By: Automatic (no FEMA validation) \\
\hline & & Date: $1 / 14 / 2002$ \\
\hline Study Category: & RIVERINE & Need Types: Changes to floodplain width \\
\hline Flooding Source: & Androscroggin River & \\
\hline Status: & Existing & \\
\hline
\end{tabular}

\section{NEED FLOODPLAIN DATA}

Anticipated BFE Change:

Increased By Less Than 1 foot

Length of Study:

0.45 miles

Average Width of Floodplain: $\quad 800$ feet

Location of Floodplain:

\section{PANELS AFFECTED BY THE NEED}

$3300320010 \mathrm{C}(05 / 02 / 1994)$

\begin{tabular}{llll}
\hline \multicolumn{4}{l}{ ORIGIN OF NEED INFORMATION } \\
Entity: & Region I Office & Phone: & Unspecified Ext: Unspecified \\
Last Name: & Unspecified & First Name: & Unspecified \\
Address 1: & Unspecified & Title: & Unspecified \\
Address 2: & Unspecified & Email: & Unspecified \\
City: & Unspecified & Fax: & Unspecified \\
State: & Unspecified & Zip: & Unspecified
\end{tabular}

\section{NEED NOTES AND COMMENTS}

There are no notes for this need. 


\begin{tabular}{|c|c|c|}
\hline \\
\hline \multicolumn{3}{|c|}{$\begin{array}{l}\text { GENERAL COMMUNITY INFORMATION } \\
\text { Community: } \quad \text { JEFFERSON, TOWN OF }\end{array}$} \\
\hline County: & COOS COUNTY & New Hampshire \\
\hline
\end{tabular}

\begin{tabular}{|c|c|c|}
\hline \multicolumn{3}{|c|}{ NEED DETAIL INFORMATION } \\
\hline Need ID: & 100000000010627 & Entered By: Chuck Wood \\
\hline \multirow[t]{3}{*}{ Source: } & FEMA 5-year letter & Date: 05/08/1998 \\
\hline & & Approved By: FEMA \\
\hline & & Date: $5 / 8 / 1998$ \\
\hline Study Category: & RIVERINE & Need Types: Changes to hydraulic analysis \\
\hline Flooding Source: & ISRAEL RIVER & \\
\hline Status: & Existing & \\
\hline
\end{tabular}

\section{NEED FLOODPLAIN DATA}

Anticipated BFE Change:

Increased By Greater Than 5 feet

Length of Study:

10.77 miles

Average Width of Floodplain: $\quad 895$ feet

Location of Floodplain:

\section{PANELS AFFECTED BY THE NEED}

No panels have been associated with this need.

\begin{tabular}{|c|c|c|c|c|c|}
\hline \multicolumn{6}{|c|}{ ORIGIN OF NEED INFORMATION } \\
\hline Entity: & ASPM & Phone: & Unspecified & Ext: & Unspecified \\
\hline Last Name: & Unspecified & First Name: & Unspecified & & \\
\hline Address 1: & Unspecified & Title: & Unspecified & & \\
\hline Address 2: & Unspecified & Email: & Unspecified & & \\
\hline City: & Unspecified & Fax: & Unspecified & & \\
\hline State: & Unspecified & Zip: & Unspecified & & \\
\hline
\end{tabular}

\begin{tabular}{lll|}
\hline \multicolumn{2}{|l|}{ NEED NOTES AND COMMENTS } \\
\hline Date & Entered By & Note \\
05/08/1998 & Chuck Wood & UPDATE THIS 11 X 17 TO Z FOLD FORMAT \\
05/08/1998 & Chuck Wood & UPDATE THIS 11 X 17 TO Z FOLD FORMAT \\
\hline
\end{tabular}




\title{
FEMA Map Modernization Program Coos County Scoping
}

\section{Scoping Meeting Conference Call Meeting Minutes}

\author{
September 1, 2005
}

U.S. Geological Survey (USGS) held a kick-off meeting via conference call on September 1, 2005, with representatives from New Hampshire Office of Emergency Management (NHOEM), Federal Emergency Management Agency (FEMA), USGS, and Watershed Concepts (RMC - Regional Management Center) to introduce the scoping project team and review roles and responsibilities.

As one of the scoping study process requirements, this conference call was held to review the USGS role in the scoping project process in four counties in New Hampshire (Merrimack, Coos, Belknap, and Carroll Counties) as well as to detail the data requirements of USGS in order to determine restudy needs and prioritization of restudies in these four counties.

\section{Attendance:}

- Dean Savramis, FEMA Map Modernization Coordinator

- Brent McCarthy and Jeff Burm, Watershed Concepts (RMC)

- Fay Rubin, GIS Manager at Complex Systems Research Center, University of New Hampshire

- Robert Flynn, Craig Johnston, and Laura Hayes, USGS

- Joanne Cassulo and Jennifer DeLong, Map Modernization Coordinators, NHOEM

\section{Minutes:}

1. Dean Savramis (FEMA) - Provided an overview of the Map Modernization Program and Scoping. He also provided a description of the countywide approach.

2. Brent McCarthy (Watershed Concepts) - Describe the role of the RMC in assisting FEMA and the mapping contractors. Description of the WISE computer applications developed for FEMA to standardize the scoping process methodology, data collection, and storage for the map modernization program. Description of the DFIRM Production tool.

3. Joanne Cassulo and Jennifer DeLong (NHOEM) — Spoke about CAVs to collect information. NHOEM is providing copies of LOMAs. Joanne mentioned that the regional planning commissions have a lot of data available and can provide community contacts. 
4. Jeff Burm (Watershed Concepts) — mentioned that FEMA's Community Information System (CIS) has CAVs and CACs and access can be gotten from Mike Goetz at FEMA. He also spoke about the WISE scoping tool and various features of this tool including community contact information, available GIS data, stream data, statistical analysis, stream mile information to calculate costs for hydrology and hydraulics, LOMAs, CAVs and CACs, creation of reports for each of the items.

5. Fay Rubin (GRANIT, UNH Complex Systems)—Fay spoke about the Map Modernization work that is being done at FEMA and that she is using DOQs in her map modernization work. Fay mentioned that the Merrimack County digitization is complete, that the Belknap and Carroll County digitization will be complete by December and that the Coos County digitization will be complete next year (due by December of 2006). She stated that NHDOT is in the process of updating DOQs ion southeastern New Hampshire and that they are looking for a vendor to process the data. She mentioned that the 2003 NAIP color DOQs may not meet FEMA specifications. She has the NAIP DOQs in New Hampshire State Plane coordinates (our NAIP DOQs are in UTM projection).

6. Fay Rubin, Craig Johnston, Laura Hayes and Rob Flynn (GRANIT; USGS)—discussed available data and coverages within New Hampshire (for example, 2003 NAIP color DOQs). Remote sensing, base map information, GIS data (for example, contour data, E911 data, DEMs, buildings layer, survey data available from NHDOT). County Regional Planning Commissions may also have data.

7. USGS and NHOEM-Discuss follow-up meetings with communities to discuss prioritization. USGS will need to coordinate with NHOEM and Watershed Concepts to obtain mailing lists for communities and set a date to meet with representatives from each of the towns in each of the counties. Brent McCarthy mentioned that it may be a good idea to set up a morning and evening meeting with each county in order to be able to talk to all of the representatives in each town (two meetings for each county). Brent McCarthy also mentioned that Watershed Concepts could lead breakout sessions with towns during the meetings with the counties. 


\section{Coos County Interview Form \\ FEMA Map Modernization Program}

Date: Effective FIS/FIRM Date:

Community: Form of Government:

CID\#: If Town Government, Date of Annual Town Meeting:

\section{Community Representative:}

Name:

Title:

Telephone \#: Email:

Fax:

Other Appropriate Community Contacts:

1. Known problems with current FIRMs and FISs for the community (general details on next pages).

a. Base Map Issues (note FIRM panel numbers): (for example, poor/mixed map scales, panels not printed, change in corporate boundaries, etc.)

b. Flood plain Issues (note FIRM panel numbers): (for example, need flood elevations, disagree with flood plain boundaries, flood elevations too high/low, comments from MNUSS or best available data)

2. Areas of approximate study (for example, Zone A's) where detailed re-studies should be considered: 
3. Areas not mapped/no flood plain where approximate or detailed studies should be considered:

4. Changes to structures within the town that may affect river hydraulics (for example, reconstruction or removal of dams, changes to bridges and culverts, etc.):

5. Areas of increased/proposed development within the flood plain since the effective FIS:

1. Availability of mapping at the town level:

a. Aerial Photography (flight date, scale, color/black and white):

b. Topography (contour interval):

c. Other:

2. Future community data acquisition plans/wants/needs:

3. Information on GIS programs in-place or GIS plans that may benefit from a new FIRM:

4. Other comments:

5. Action Items:

Additional Notes: 


\section{Appendix D. Prioritized Flooding Sources}


Appendix D. Prioritized flooding sources in Coos County.

[CID, Community Identification; FIS, Flood Insurance Studies; LOMC, Letter of Map Change; --, no data]

\begin{tabular}{|c|c|c|c|c|c|c|c|c|c|c|c|c|c|c|c|c|c|c|}
\hline Community & CID & Reach_ID & Description & $\begin{array}{c}\text { Current } \\
\text { analysis } \\
\text { effective } \\
\text { date }\end{array}$ & $\begin{array}{c}\text { Current } \\
\text { effective } \\
\text { zone }\end{array}$ & $\begin{array}{l}\text { Study } \\
\text { reach } \\
\text { length } \\
\text { (ft) }\end{array}$ & Study type & $\begin{array}{c}\text { Com- } \\
\text { munity } \\
\text { priority } \\
\text { range }\end{array}$ & $\begin{array}{c}\text { Com- } \\
\text { munity } \\
\text { priority }\end{array}$ & $\begin{array}{c}\text { Popu- } \\
\text { lation } \\
\text { density } \\
\text { score }\end{array}$ & $\begin{array}{c}\text { Popu- } \\
\text { lation } \\
\text { growth } \\
\text { score }\end{array}$ & $\begin{array}{c}\text { Year } \\
\text { since } \\
\text { most } \\
\text { recent } \\
\text { FIS } \\
\text { score }\end{array}$ & $\begin{array}{c}\text { Signif- } \\
\text { icant } \\
\text { area } \\
\text { score }\end{array}$ & $\begin{array}{c}\text { De- } \\
\text { velop- } \\
\text { ment } \\
\text { score }\end{array}$ & $\begin{array}{l}\text { LOMC } \\
\text { score }\end{array}$ & $\begin{array}{c}\text { Com- } \\
\text { munity } \\
\text { priority } \\
\text { value }\end{array}$ & $\begin{array}{c}\text { Com- } \\
\text { munity } \\
\text { ranking } \\
\text { value }\end{array}$ & $\begin{array}{l}\text { Total } \\
\text { score }\end{array}$ \\
\hline Berlin & 330029\# & $\begin{array}{l}\text { \{EF826111-A1BD-4D2A- } \\
\text { 8D3C-A5CF62117D30\} }\end{array}$ & $\begin{array}{l}\text { Dead River } \\
(1109067.78,721426.40)\end{array}$ & $6 / 15 / 1982$ & A & $5,491.2$ & $\begin{array}{l}\text { Detailed study/ } \\
\text { Riverine }\end{array}$ & High & 1 & 10 & 0 & 8 & 5 & 5 & 0 & 20 & 10 & 58 \\
\hline Gorham & 330032\# & $\begin{array}{l}\{06770 \mathrm{~A} 5 \mathrm{~A}-068 \mathrm{E}-4 \mathrm{E} 8 \mathrm{~B}- \\
94 \mathrm{C} 6-7780 \mathrm{ED} 215 \mathrm{BBC}\}\end{array}$ & $\begin{array}{l}\text { Androscoggin River } \\
(1106502.11,694140.58)\end{array}$ & $5 / 2 / 1994$ & $\mathrm{AE}$ & $13,516.8$ & $\begin{array}{l}\text { Detailed study/ } \\
\text { Riverine }\end{array}$ & High & 1 & 10 & 0 & 4 & 5 & 5 & 0 & 20 & 10 & 54 \\
\hline Lancaster & 335277\# & $\begin{array}{l}\text { \{52A9DAEF-E1AF-4168- } \\
\text { 9836-01F77240FA70\} }\end{array}$ & $\begin{array}{l}\text { Connecticut River } \\
(1005374.06,734310.39)\end{array}$ & $4 / 1 / 1982$ & $\mathrm{AE}$ & $5,596.8$ & Redelineation & $\begin{array}{l}\text { Medium } \\
\text { High }\end{array}$ & 3 & 10 & 0 & 8 & 5 & 5 & 5 & 15 & 6 & 54 \\
\hline Carroll & 330030B & $\begin{array}{l}\{\mathrm{B} 1728 \mathrm{FE} 5-7729-4 \mathrm{~F} 4 \mathrm{~B}- \\
\text { A128-24E35E52BD0B }\}\end{array}$ & $\begin{array}{l}\text { Ammonoosuc River } \\
(1045400.96,641069.25)\end{array}$ & 4/15/1986 & A & $52,958.4$ & $\begin{array}{l}\text { Detailed study/ } \\
\text { Riverine }\end{array}$ & $\begin{array}{l}\text { Medium } \\
\text { High }\end{array}$ & 1 & 8 & 4 & 6 & 5 & 5 & 0 & 15 & 10 & 53 \\
\hline Lancaster & 335277\# & $\begin{array}{l}\text { \{DF7F66A7-9355-4D87- } \\
\text { 9625-476ECA94058E }\end{array}$ & $\begin{array}{l}\text { Israel River } \\
(1018189.65,718866.81)\end{array}$ & $4 / 1 / 1982$ & $\mathrm{AE}$ & $16,579.2$ & $\begin{array}{l}\text { Limited } \\
\text { Detailed study }\end{array}$ & $\begin{array}{l}\text { Medium } \\
\text { High }\end{array}$ & 1 & 10 & 0 & 8 & 5 & 5 & 0 & 15 & 10 & 53 \\
\hline Gorham & 330032\# & $\begin{array}{l}\{1 \mathrm{BAEEC} 3 \mathrm{D}-8 \mathrm{~A} 94-45 \mathrm{~F} 4- \\
\text { 94B2-08279E4040F0 }\end{array}$ & $\begin{array}{l}\text { Peabody River } \\
(1113936.09,685771.50)\end{array}$ & $5 / 2 / 1994$ & $\mathrm{AE}$ & $4,804.8$ & $\begin{array}{l}\text { Limited } \\
\text { Detailed study }\end{array}$ & High & 2 & 10 & 0 & 4 & 5 & 5 & 0 & 20 & 8 & 52 \\
\hline Jefferson & $330033 \mathrm{C}$ & $\begin{array}{l}\text { \{EAF2F724-80DB-48C8- } \\
\text { 800A-11DA748FAE95\} }\end{array}$ & $\begin{array}{l}\text { Israel River } \\
(1020103.49,707831.59)\end{array}$ & 4/15/1986 & A & $4,118.4$ & $\begin{array}{l}\text { Detailed study/ } \\
\text { Riverine }\end{array}$ & $\begin{array}{l}\text { Medium } \\
\text { High }\end{array}$ & 1 & 10 & 1 & 6 & 5 & 5 & 0 & 15 & 10 & 52 \\
\hline Whitefield & 330040\# & $\begin{array}{l}\text { \{8A547472-45CF-47A0- } \\
\text { 906D-D4909E615624\} }\end{array}$ & $\begin{array}{l}\text { Johns River } \\
(1001427.61,681564.81)\end{array}$ & $4 / 2 / 1986$ & A & $7,603.2$ & $\begin{array}{l}\text { Detailed study/ } \\
\text { Riverine }\end{array}$ & $\begin{array}{l}\text { Medium } \\
\text { High }\end{array}$ & 1 & 10 & 1 & 6 & 5 & 5 & 0 & 15 & 10 & 52 \\
\hline Berlin & 330029\# & $\begin{array}{l}\{7 \mathrm{E} 773 \mathrm{BEC}-\mathrm{E} 426-480 \mathrm{~F}- \\
\text { B724-513AB66D8C59\} }\end{array}$ & $\begin{array}{l}\text { Androscoggin River } \\
\text { (1110341.05, 716380.99) }\end{array}$ & $6 / 15 / 1982$ & $\mathrm{AE}$ & $2,376.0$ & $\begin{array}{l}\text { Detailed study/ } \\
\text { Riverine }\end{array}$ & $\begin{array}{l}\text { Medium } \\
\text { High }\end{array}$ & 2 & 10 & 0 & 8 & 5 & 5 & 0 & 15 & 8 & 51 \\
\hline Colebrook & 330031\# & $\begin{array}{l}\text { \{3ED43855-E4B7-4BB8- } \\
\text { B6A2-6F94E709697C }\end{array}$ & $\begin{array}{l}\text { Mohawk River } \\
(1036098.58,870847.88)\end{array}$ & $5 / 17 / 1989$ & A & $12,249.6$ & $\begin{array}{l}\text { Detailed study/ } \\
\text { Riverine }\end{array}$ & $\begin{array}{l}\text { Medium } \\
\text { High }\end{array}$ & 1 & 10 & 0 & 6 & 5 & 5 & 0 & 15 & 10 & 51 \\
\hline Lancaster & 335277\# & $\begin{array}{l}\text { \{AD2BDCFE-A89A-484C- } \\
\text { 9954-9AFDD7172CF9\} }\end{array}$ & $\begin{array}{l}\text { Indian Brook } \\
(1013272.09,727383.23)\end{array}$ & $4 / 1 / 1982$ & $\mathrm{AE}$ & $7,656.0$ & $\begin{array}{l}\text { Detailed study/ } \\
\text { Riverine }\end{array}$ & $\begin{array}{l}\text { Medium } \\
\text { High }\end{array}$ & 2 & 10 & 0 & 8 & 5 & 5 & 0 & 15 & 8 & 51 \\
\hline Northumberland & 330036\# & $\begin{array}{l}\{\text { CB2FD475-705E-4683- } \\
\text { 9218-2353A84B202E }\}\end{array}$ & $\begin{array}{l}\text { Connecticut River } \\
(1014645.11,765642.24)\end{array}$ & $5 / 4 / 1989$ & $\mathrm{AE}$ & $41,764.8$ & Redelineation & $\begin{array}{l}\text { Medium } \\
\text { High }\end{array}$ & 1 & 10 & 0 & 6 & 5 & 5 & 0 & 15 & 10 & 51 \\
\hline Stewartstown & $330194 \mathrm{~A}$ & $\begin{array}{l}\{\text { BDC5EF3E-CE69-4FF1- } \\
\text { 9ED4-616F0FC43BF5 }\}\end{array}$ & $\begin{array}{l}\text { Connecticut River } \\
(1026677.05,914027.91)\end{array}$ & $1 / 10 / 1975$ & A & $8,342.4$ & $\begin{array}{l}\text { Detailed study/ } \\
\text { Riverine }\end{array}$ & $\begin{array}{l}\text { Medium } \\
\text { High }\end{array}$ & 1 & 10 & 0 & 1 & 5 & 5 & 5 & 15 & 10 & 51 \\
\hline Stewartstown & $330194 \mathrm{~A}$ & $\begin{array}{l}\{84 F 976 \mathrm{D} 0-07 \mathrm{C} 4-4 \mathrm{~B} 29- \\
\text { A329-9016B5B1F5B7\} }\end{array}$ & $\begin{array}{l}\text { Connecticut River } \\
(1030331.30,911600.27)\end{array}$ & $1 / 10 / 1975$ & A & $5,174.4$ & $\begin{array}{l}\text { Detailed study/ } \\
\text { Riverine }\end{array}$ & $\begin{array}{l}\text { Medium } \\
\text { High }\end{array}$ & 1 & 10 & 0 & 1 & 5 & 5 & 5 & 15 & 10 & 51 \\
\hline Stewartstown & $330194 \mathrm{~A}$ & $\begin{array}{l}\{34 \mathrm{C} 15 \mathrm{C} 47-\mathrm{BE} 2 \mathrm{D}-4476- \\
\text { B73D-20E96DA01092\} }\end{array}$ & $\begin{array}{l}\text { Connecticut River } \\
(1019076.32,910281.45)\end{array}$ & $1 / 10 / 1975$ & A & $15,576.0$ & $\begin{array}{l}\text { Detailed study/ } \\
\text { Riverine }\end{array}$ & $\begin{array}{l}\text { Medium } \\
\text { High }\end{array}$ & 1 & 10 & 0 & 1 & 5 & 5 & 5 & 15 & 10 & 51 \\
\hline Stratford & 330039\# & $\begin{array}{l}\{94734 \mathrm{D} 03-544 \mathrm{C}-49 \mathrm{ED}- \\
\text { 8AE8-64269C77C4D7\} }\end{array}$ & $\begin{array}{l}\text { Bog Brook } \\
(1024691.46,801658.25)\end{array}$ & $4 / 18 / 1983$ & A & $27,456.0$ & $\begin{array}{l}\text { Detailed study/ } \\
\text { Riverine }\end{array}$ & $\begin{array}{l}\text { Medium } \\
\text { High }\end{array}$ & 1 & 8 & 0 & 8 & 5 & 5 & 0 & 15 & 10 & 51 \\
\hline Colebrook & 330031\# & $\begin{array}{l}\{3 \mathrm{DB} 0 \mathrm{E} 255-1940-44 \mathrm{~F} 7- \\
\text { AB1B-08CF6FB8B19E }\}\end{array}$ & $\begin{array}{l}\text { Beaver Brook } \\
(1034069.69,878726.63)\end{array}$ & $5 / 17 / 1989$ & A & $10,137.6$ & $\begin{array}{l}\text { Detailed study/ } \\
\text { Riverine }\end{array}$ & $\begin{array}{l}\text { Medium } \\
\text { High }\end{array}$ & 2 & 10 & 0 & 6 & 5 & 5 & 0 & 15 & 8 & 49 \\
\hline Northumberland & 330036\# & $\begin{array}{l}\{3 \mathrm{E} 303 \mathrm{E} 54-\mathrm{F} 447-42 \mathrm{~A} 5- \\
\text { 85D0-756368B8710F\} }\end{array}$ & $\begin{array}{l}\text { Upper Ammonoosuc R } \\
(1032631.77,770992.34)\end{array}$ & $5 / 4 / 1989$ & A & $25,608.0$ & $\begin{array}{l}\text { Detailed study/ } \\
\text { Riverine }\end{array}$ & $\begin{array}{l}\text { Medium } \\
\text { High }\end{array}$ & 2 & 10 & 0 & 6 & 5 & 5 & 0 & 15 & 8 & 49 \\
\hline Gorham & 330032\# & $\begin{array}{l}\text { \{FBF4C6E8-CB1B-45E5- } \\
\text { BB6A-A6C33D428C37\} }\end{array}$ & $\begin{array}{l}\text { Moose River } \\
(1105628.71,691573.84)\end{array}$ & $5 / 2 / 1994$ & $\mathrm{AE}$ & $4,118.4$ & $\begin{array}{l}\text { Detailed study/ } \\
\text { Riverine }\end{array}$ & High & 4 & 10 & 0 & 4 & 5 & 5 & 0 & 20 & 4 & 48 \\
\hline Gorham & 330032\# & $\begin{array}{l}\{28 D 1 A 06 C-326 \mathrm{~A}-4 \mathrm{~F} 21- \\
\text { BD6F-23439404CD06 }\}\end{array}$ & $\begin{array}{l}\text { Moose Brook } \\
(1104157.36,693160.68)\end{array}$ & $5 / 2 / 1994$ & $\mathrm{AE}$ & $3,854.4$ & $\begin{array}{l}\text { Limited } \\
\text { Detailed study }\end{array}$ & High & 5 & 10 & 0 & 4 & 5 & 5 & 0 & 20 & 4 & 48 \\
\hline
\end{tabular}


Appendix D. Prioritized flooding sources in Coos County.-Continued

[CID, Community Identification; FIS, Flood Insurance Studies; LOMC, Letter of Map Change; --, no data]

\begin{tabular}{|c|c|c|c|c|c|c|c|c|c|c|c|c|c|c|c|c|c|c|}
\hline Community & CID & Reach_ID & Description & $\begin{array}{c}\text { Current } \\
\text { analysis } \\
\text { effective } \\
\text { date }\end{array}$ & $\begin{array}{c}\text { Current } \\
\text { effective } \\
\text { zone }\end{array}$ & $\begin{array}{c}\text { Study } \\
\text { reach } \\
\text { length } \\
\text { (ft) }\end{array}$ & Study type & $\begin{array}{l}\text { Com- } \\
\text { munity } \\
\text { priority } \\
\text { range }\end{array}$ & $\begin{array}{l}\text { Com- } \\
\text { munity } \\
\text { priority }\end{array}$ & $\begin{array}{l}\text { Popu- } \\
\text { lation } \\
\text { density } \\
\text { score }\end{array}$ & $\begin{array}{l}\text { Popu- } \\
\text { lation } \\
\text { growth } \\
\text { score }\end{array}$ & $\begin{array}{c}\text { Year } \\
\text { since } \\
\text { most } \\
\text { recent } \\
\text { FIS } \\
\text { score }\end{array}$ & $\begin{array}{c}\text { Signif- } \\
\text { icant } \\
\text { area } \\
\text { score }\end{array}$ & $\begin{array}{c}\text { De- } \\
\text { velop- } \\
\text { ment } \\
\text { score }\end{array}$ & $\begin{array}{l}\text { LOMC } \\
\text { score }\end{array}$ & $\begin{array}{l}\text { Com- } \\
\text { munity } \\
\text { priority } \\
\text { value }\end{array}$ & $\begin{array}{l}\text { Com- } \\
\text { munity } \\
\text { ranking } \\
\text { value }\end{array}$ & $\begin{array}{l}\text { Total } \\
\text { score }\end{array}$ \\
\hline Errol & 330206\# & $\begin{array}{l}\{5 \text { 5591A6B-2F3B-4CA8- } \\
\text { B9D2-61FFB20E54E9 }\}\end{array}$ & $\begin{array}{l}\text { Clear Stream } \\
(1118095.00,833305.92)\end{array}$ & $1 / 17 / 1975$ & A & $5,702.4$ & $\begin{array}{l}\text { Detailed study/ } \\
\text { Riverine }\end{array}$ & High & 2 & 8 & 0 & 1 & 5 & 5 & 0 & 20 & 8 & 47 \\
\hline Milan & $330035 \mathrm{~A}$ & $\begin{array}{l}\text { AAE44CCEC-F5F7-4676- } \\
\text { ADAF-BF5DE63A64E0 }\end{array}$ & $\begin{array}{l}\text { Upper Ammonoosuc R } \\
(1079439.75,758782.93)\end{array}$ & $3 / 31 / 2005$ & A & $3,854.4$ & Redelineation & $\begin{array}{l}\text { Medium } \\
\text { High }\end{array}$ & 1 & 10 & 1 & 6 & 0 & 0 & 5 & 15 & 10 & 47 \\
\hline Carroll & 330030B & $\begin{array}{l}\text { \{80A53C11-0047-4A97- } \\
\text { 8A42-FFD595D6E9D4\} }\end{array}$ & $\begin{array}{l}\text { Crawford Brook } \\
(1046204.18,635458.68)\end{array}$ & 4/15/1986 & A & $7,550.4$ & $\begin{array}{l}\text { Detailed study/ } \\
\text { Riverine }\end{array}$ & $\begin{array}{l}\text { Medium } \\
\text { High }\end{array}$ & 2 & 8 & 4 & 6 & 0 & 5 & 0 & 15 & 8 & 46 \\
\hline Stewartstown & 330194A & $\begin{array}{l}\text { \{7D6FA2C9-C12C-4E3B- } \\
\text { 8C7B-0CF406698F99\} }\end{array}$ & $\begin{array}{l}\text { Connecticut River } \\
(1021754.09,898675.60)\end{array}$ & $1 / 10 / 1975$ & A & $12,196.8$ & $\begin{array}{l}\text { Detailed study/ } \\
\text { Riverine }\end{array}$ & $\begin{array}{l}\text { Medium } \\
\text { High }\end{array}$ & 1 & 10 & 0 & 1 & 5 & 5 & 0 & 15 & 10 & 46 \\
\hline Stewartstown & $330194 \mathrm{~A}$ & $\begin{array}{l}\text { \{CA2CD62B-2F65-4424- } \\
\text { 8394-7841BB02BD78\} }\end{array}$ & $\begin{array}{l}\text { Connecticut River } \\
(1021404.12,899627.41)\end{array}$ & $1 / 10 / 1975$ & A & 792.0 & $\begin{array}{l}\text { Detailed study/ } \\
\text { Riverine }\end{array}$ & $\begin{array}{l}\text { Medium } \\
\text { High }\end{array}$ & 1 & 10 & 0 & 1 & 5 & 5 & 0 & 15 & 10 & 46 \\
\hline Dummer & 330201 & $\begin{array}{l}\text { \{75D07179-95B0-49E0- } \\
\text { 8CCD-AD787013C8A9\} }\end{array}$ & $\begin{array}{l}\text { Androscoggin River } \\
(1096575.75,778175.62)\end{array}$ & 1/17/1975 & A & $21,225.6$ & $\begin{array}{l}\text { Detailed study/ } \\
\text { Riverine }\end{array}$ & $\begin{array}{l}\text { Medium } \\
\text { High }\end{array}$ & 1 & 8 & 0 & 2 & 5 & 5 & 0 & 15 & 10 & 45 \\
\hline Jefferson & $330033 \mathrm{C}$ & $\begin{array}{l}\{2 \mathrm{C} 85 \text { FD5F-F408-4919- } \\
\text { 9460-42FBF2A2CE8F }\}\end{array}$ & $\begin{array}{l}\text { Israel River } \\
(1034059.14,686484.30)\end{array}$ & 4/15/1986 & A & $17,054.4$ & $\begin{array}{l}\text { Detailed study/ } \\
\text { Riverine }\end{array}$ & $\begin{array}{l}\text { Medium } \\
\text { High }\end{array}$ & 2 & 10 & 1 & 6 & 0 & 5 & 0 & 15 & 8 & 45 \\
\hline Berlin & 330029\# & $\begin{array}{l}\text { \{B40A7F6E-30DB-4C09- } \\
\text { 98D6-ACB4AEB73FF2 }\end{array}$ & $\begin{array}{l}\text { Dead River } \\
(1107109.82,723201.78)\end{array}$ & 6/15/1982 & $\mathrm{AE}$ & $2,798.4$ & $\begin{array}{l}\text { Limited } \\
\text { Detailed study }\end{array}$ & Medium & 3 & 10 & 0 & 8 & 5 & 5 & 0 & 10 & 6 & 44 \\
\hline Carroll & 330030B & $\begin{array}{l}\{64 \mathrm{C} 0 \mathrm{ECBF}-1 \mathrm{FEC}-4 \mathrm{E} 90- \\
\text { A7DD-1884D1CB0AAF }\}\end{array}$ & $\begin{array}{l}\text { Unnamed } \\
(1045294.69,636300.85)\end{array}$ & 4/15/1986 & A & $2,692.8$ & $\begin{array}{l}\text { Detailed study/ } \\
\text { Riverine }\end{array}$ & $\begin{array}{l}\text { Medium } \\
\text { High }\end{array}$ & 3 & 8 & 4 & 6 & 0 & 5 & 0 & 15 & 6 & 44 \\
\hline Stewartstown & 330194A & $\begin{array}{l}\{677 \text { F01B0-A54A-4C5A- } \\
8092-9 \mathrm{~A} 088273122 \mathrm{E}\}\end{array}$ & $\begin{array}{l}\text { Day Brook } \\
(1024806.63,910905.48)\end{array}$ & 1/10/1975 & A & $14,361.6$ & $\begin{array}{l}\text { Detailed study/ } \\
\text { Riverine }\end{array}$ & $\begin{array}{l}\text { Medium } \\
\text { High }\end{array}$ & 2 & 10 & 0 & 1 & 0 & 5 & 5 & 15 & 8 & 44 \\
\hline Colebrook & 330031\# & $\begin{array}{l}\{1 \text { A6D20E0-F9CC-4C1B- } \\
\text { 8479-AB1CA6644B78 }\end{array}$ & $\begin{array}{l}\text { Mohawk River } \\
\text { (1058824.04, 865053.63) }\end{array}$ & $5 / 17 / 1989$ & A & $5,596.8$ & $\begin{array}{l}\text { Limited } \\
\text { Detailed study }\end{array}$ & $\begin{array}{l}\text { Medium } \\
\text { High }\end{array}$ & 3 & 10 & 0 & 6 & 0 & 0 & 5 & 15 & 6 & 42 \\
\hline Northumberland & 330036\# & $\begin{array}{l}\text { \{D6F2F671-D5B8-4B46- } \\
\text { 98BF-B1A6205ACA17\} }\end{array}$ & $\begin{array}{l}\text { Dean Brook } \\
(1017706.86,750187.98)\end{array}$ & $5 / 4 / 1989$ & A & $7,603.2$ & $\begin{array}{l}\text { Detailed study/ } \\
\text { Riverine }\end{array}$ & $\begin{array}{l}\text { Medium } \\
\text { High }\end{array}$ & 3 & 10 & 0 & 6 & 0 & 5 & 0 & 15 & 6 & 42 \\
\hline Shelburne & $330037 \mathrm{~A}$ & $\begin{array}{l}\{4 \mathrm{FA} 537 \mathrm{FC}-\mathrm{F} 426-4 \mathrm{~A} 07- \\
\text { 849B-A99853E2D3D1\} }\end{array}$ & $\begin{array}{l}\text { Androscoggin River } \\
(1139760.15,695778.43)\end{array}$ & $4 / 2 / 1986$ & A & $19,694.4$ & Redelineation & $\begin{array}{l}\text { Medium } \\
\text { High }\end{array}$ & 2 & 8 & 0 & 6 & 0 & 0 & 5 & 15 & 8 & 42 \\
\hline Stratford & 330039\# & $\begin{array}{l}\text { \{ED14B726-5ECD-44A8- } \\
\text { A58E-8EBBBFF61BBF\} }\end{array}$ & $\begin{array}{l}\text { Gay Brook } \\
(1018596.70,798798.18)\end{array}$ & 4/18/1983 & A & $2,534.4$ & $\begin{array}{l}\text { Detailed study/ } \\
\text { Riverine }\end{array}$ & $\begin{array}{l}\text { Medium } \\
\text { High }\end{array}$ & 2 & 8 & 0 & 8 & 0 & 5 & 0 & 15 & 6 & 42 \\
\hline Columbia & $330185 \mathrm{~A}$ & $\begin{array}{l}\{\text { C97DB9CD-5C66-43F1- } \\
\text { B314-1BBD73D5537B }\}\end{array}$ & $\begin{array}{l}\text { Connecticut River } \\
(1021763.15,867686.18)\end{array}$ & $4 / 2 / 1986$ & A & $55,598.4$ & $\begin{array}{l}\text { Detailed study/ } \\
\text { Riverine }\end{array}$ & $\begin{array}{l}\text { Medium } \\
\text { High }\end{array}$ & 1 & 8 & 2 & 6 & 0 & 0 & 0 & 15 & 10 & 41 \\
\hline Northumberland & 330036\# & $\begin{array}{l}\text { \{3DB9571B-045C-4B29- } \\
\text { B1C5-518057741F7D }\}\end{array}$ & $\begin{array}{l}\text { Dean Brook } \\
(1024006.30,748311.38)\end{array}$ & $5 / 4 / 1989$ & A & $10,824.0$ & $\begin{array}{l}\text { Detailed study/ } \\
\text { Riverine }\end{array}$ & $\begin{array}{l}\text { Medium } \\
\text { High }\end{array}$ & 5 & 10 & 0 & 6 & 0 & 5 & 0 & 15 & 4 & 40 \\
\hline Northumberland & 330036\# & $\begin{array}{l}\{32 \mathrm{C} 118 \mathrm{E} 4-4 \mathrm{D} 7 \mathrm{~B}-4332- \\
\text { 8FB4-02AAFE66606\} }\end{array}$ & $\begin{array}{l}\text { Potter Brook } \\
(1025517.41,772647.25)\end{array}$ & $5 / 4 / 1989$ & A & $4,065.6$ & $\begin{array}{l}\text { Detailed study/ } \\
\text { Riverine }\end{array}$ & $\begin{array}{l}\text { Medium } \\
\text { High }\end{array}$ & 7 & 10 & 0 & 6 & 0 & 5 & 0 & 15 & 4 & 40 \\
\hline Shelburne & 330037A & $\begin{array}{l}\text { \{E5B6493D-54F2-475D- } \\
\text { 8AE4-67B81852B855\} }\end{array}$ & $\begin{array}{l}\text { Clement Brook } \\
(1138198.74,689519.28)\end{array}$ & $4 / 2 / 1986$ & -- & $7,180.8$ & $\begin{array}{l}\text { Detailed study/ } \\
\text { Riverine }\end{array}$ & $\begin{array}{l}\text { Medium } \\
\text { High }\end{array}$ & 3 & 8 & 0 & 6 & 0 & 5 & 0 & 15 & 6 & 40 \\
\hline Columbia & $330185 \mathrm{~A}$ & $\begin{array}{l}\{87 E A A 8 C C-B 27 C-4360- \\
\text { 9115-29741DA078CB }\}\end{array}$ & $\begin{array}{l}\text { Simms Stream } \\
(1022930.61,865559.53)\end{array}$ & $4 / 2 / 1986$ & -- & $2,904.0$ & $\begin{array}{l}\text { Detailed study/ } \\
\text { Riverine }\end{array}$ & $\begin{array}{l}\text { Medium } \\
\text { High }\end{array}$ & 2 & 8 & 2 & 6 & 0 & 0 & 0 & 15 & 8 & 39 \\
\hline Errol & 330206\# & $\begin{array}{l}\text { \{8A0DCA61-E7A0-42AA- } \\
\text { 82C5-12A935E3AB59\} }\end{array}$ & $\begin{array}{l}\text { Androscoggin River } \\
(1126840.07,834417.96)\end{array}$ & 1/17/1975 & A & $13,094.4$ & $\begin{array}{l}\text { Detailed study/ } \\
\text { Riverine }\end{array}$ & High & 1 & 8 & 0 & 1 & 0 & 0 & 0 & 20 & 10 & 39 \\
\hline
\end{tabular}


Appendix D. Prioritized flooding sources in Coos County.-Continued

[CID, Community Identification; FIS, Flood Insurance Studies; LOMC, Letter of Map Change; --, no data]

\begin{tabular}{|c|c|c|c|c|c|c|c|c|c|c|c|c|c|c|c|c|c|c|}
\hline Community & CID & Reach_ID & Description & $\begin{array}{c}\text { Current } \\
\text { analysis } \\
\text { effective } \\
\text { date }\end{array}$ & $\begin{array}{c}\text { Current } \\
\text { effective } \\
\text { zone }\end{array}$ & $\begin{array}{l}\text { Study } \\
\text { reach } \\
\text { length } \\
\text { (ft) }\end{array}$ & Study type & $\begin{array}{c}\text { Com- } \\
\text { munity } \\
\text { priority } \\
\text { range }\end{array}$ & $\begin{array}{c}\text { Com- } \\
\text { munity } \\
\text { priority }\end{array}$ & $\begin{array}{c}\text { Popu- } \\
\text { lation } \\
\text { density } \\
\text { score }\end{array}$ & $\begin{array}{c}\text { Popu- } \\
\text { lation } \\
\text { growth } \\
\text { score }\end{array}$ & $\begin{array}{c}\text { Year } \\
\text { since } \\
\text { most } \\
\text { recent } \\
\text { FIS } \\
\text { score }\end{array}$ & $\begin{array}{c}\text { Signif- } \\
\text { icant } \\
\text { area } \\
\text { score }\end{array}$ & $\begin{array}{c}\text { De- } \\
\text { velop- } \\
\text { ment } \\
\text { score }\end{array}$ & $\begin{array}{l}\text { LOMC } \\
\text { score }\end{array}$ & $\begin{array}{c}\text { Com- } \\
\text { munity } \\
\text { priority } \\
\text { value }\end{array}$ & $\begin{array}{c}\text { Com- } \\
\text { munity } \\
\text { ranking } \\
\text { value }\end{array}$ & $\begin{array}{l}\text { Total } \\
\text { score }\end{array}$ \\
\hline Shelburne & $330037 \mathrm{~A}$ & $\begin{array}{l}\{\text { 409ED0AA-794F-4C0B- } \\
\text { A91C-A0CFE8EB3901\} }\end{array}$ & $\begin{array}{l}\text { Androscoggin River } \\
(1116666.81,689619.06)\end{array}$ & $4 / 2 / 1986$ & A & $13,992.0$ & $\begin{array}{l}\text { Detailed study/ } \\
\text { Riverine }\end{array}$ & $\begin{array}{l}\text { Medium } \\
\text { High }\end{array}$ & 1 & 8 & 0 & 6 & 0 & 0 & 0 & 15 & 10 & 39 \\
\hline Stark & 330038B & $\begin{array}{l}\{96765186-E 220-4 \mathrm{AB} 4- \\
\text { 8A96-7A1417C65266\} }\end{array}$ & $\begin{array}{l}\text { Upper Ammonoosuc R } \\
(1050298.23,765775.20)\end{array}$ & $4 / 2 / 1986$ & A & $6,547.2$ & $\begin{array}{l}\text { Detailed study/ } \\
\text { Riverine }\end{array}$ & $\begin{array}{l}\text { Medium } \\
\text { High }\end{array}$ & 1 & 8 & 0 & 6 & 0 & 0 & 0 & 15 & 10 & 39 \\
\hline Stratford & 330039\# & $\begin{array}{l}\text { \{9647FA91-6C43-402D- } \\
\text { 9D79-E7D1A70E06AC }\end{array}$ & $\begin{array}{l}\text { Connecticut River } \\
(1001040.60,827782.56)\end{array}$ & $4 / 18 / 1983$ & $\mathrm{AE}$ & $23,971.2$ & Redelineation & $\begin{array}{l}\text { Medium } \\
\text { High }\end{array}$ & 1 & 8 & 0 & 8 & 0 & 0 & 0 & 15 & 8 & 39 \\
\hline Jefferson & $330033 \mathrm{C}$ & $\begin{array}{l}\text { \{849FA4EF-956F-433D- } \\
\text { 9185-96BA3C6BBE5D }\end{array}$ & $\begin{array}{l}\text { Israel River } \\
(1043876.44,682915.67)\end{array}$ & $4 / 15 / 1986$ & A & $13,833.6$ & $\begin{array}{l}\text { Detailed study/ } \\
\text { Riverine }\end{array}$ & $\begin{array}{l}\text { Medium } \\
\text { High }\end{array}$ & 3 & 10 & 1 & 6 & 0 & 0 & 0 & 15 & 6 & 38 \\
\hline Shelburne & 330037A & $\begin{array}{l}\text { \{EEEEB661-AE59-46C1- } \\
\text { AD0F-744713B8B8D5\} }\end{array}$ & $\begin{array}{l}\text { Peabody River } \\
(1116675.37,689373.28)\end{array}$ & $4 / 2 / 1986$ & $\mathrm{AE}$ & 580.8 & $\begin{array}{l}\text { Limited } \\
\text { Detailed study }\end{array}$ & $\begin{array}{l}\text { Medium } \\
\text { High }\end{array}$ & 3 & 8 & 0 & 6 & 0 & 5 & 0 & 15 & 4 & 38 \\
\hline Lancaster & $335277 \#$ & $\begin{array}{l}\text { \{3D3D8B8B-0E78-4F6C- } \\
\text { A349-E6619B3FBC6B }\}\end{array}$ & $\begin{array}{l}\text { Unnamed } \\
(1018100.50,711721.81)\end{array}$ & $4 / 1 / 1982$ & -- & $2,164.8$ & $\begin{array}{l}\text { Detailed study/ } \\
\text { Riverine }\end{array}$ & Medium & 6 & 10 & 0 & 8 & 0 & 5 & 0 & 10 & 4 & 37 \\
\hline Lancaster & 335277\# & $\begin{array}{l}\text { \{AF8EDE7E-67DE-4719- } \\
\text { BBD6-134368709994\} }\end{array}$ & $\begin{array}{l}\text { Unnamed } \\
(1030361.19,713511.85)\end{array}$ & $4 / 1 / 1982$ & A & $1,584.0$ & Redelineation & Medium & 7 & 10 & 0 & 8 & 0 & 5 & 0 & 10 & 4 & 37 \\
\hline Lancaster & 335277\# & $\begin{array}{l}\{296 \mathrm{~B} 2403-3 \mathrm{E} 81-4854- \\
\text { 92F9-589D3018646F }\end{array}$ & $\begin{array}{l}\text { Garland Brook } \\
(1028509.12,714644.32)\end{array}$ & $4 / 1 / 1982$ & A & $1,372.8$ & Redelineation & Medium & 8 & 10 & 0 & 8 & 0 & 5 & 0 & 10 & 4 & 37 \\
\hline Stark & 330038B & $\begin{array}{l}\{\mathrm{E} 84 \mathrm{C} 3 \mathrm{D} 70-3210-4 \mathrm{CFC}- \\
\text { A304-3FC0F0C02C9C }\end{array}$ & $\begin{array}{l}\text { Nash Stream } \\
(1036937.39,778042.55)\end{array}$ & $4 / 2 / 1986$ & A & $3,273.6$ & $\begin{array}{l}\text { Detailed study/ } \\
\text { Riverine }\end{array}$ & $\begin{array}{l}\text { Medium } \\
\text { High }\end{array}$ & 2 & 8 & 0 & 6 & 0 & 0 & 0 & 15 & 8 & 37 \\
\hline Stewartstown & 330194A & $\begin{array}{l}\text { \{04DF23DA-36B7-40EE- } \\
\text { A58C-39F82CA48E6F }\}\end{array}$ & $\begin{array}{l}\text { Unnamed } \\
(1025373.12,901682.98)\end{array}$ & $1 / 10 / 1975$ & A & $3,643.2$ & $\begin{array}{l}\text { Detailed study/ } \\
\text { Riverine }\end{array}$ & $\begin{array}{l}\text { Medium } \\
\text { High }\end{array}$ & 3 & 10 & 0 & 1 & 0 & 5 & 0 & 15 & 6 & 37 \\
\hline Errol & 330206\# & $\begin{array}{l}\text { \{00DBA968-773F-4211- } \\
\text { AEF9-72D6747A69C5 }\}\end{array}$ & $\begin{array}{l}\text { Greenough Brook } \\
(1117165.74,835720.11)\end{array}$ & 1/17/1975 & A & $3,115.2$ & $\begin{array}{l}\text { Detailed study/ } \\
\text { Riverine }\end{array}$ & $\begin{array}{l}\text { Medium } \\
\text { High }\end{array}$ & 3 & 8 & 0 & 1 & 0 & 0 & 5 & 15 & 6 & 35 \\
\hline Gorham & 330032\# & $\begin{array}{l}\{693 \mathrm{BF} 558-9 \mathrm{DE} 0-4 \mathrm{C} 36- \\
\text { A813-024F96C } 06464\}\end{array}$ & $\begin{array}{l}\text { Peabody River } \\
(1107106.12,673777.35)\end{array}$ & $5 / 2 / 1994$ & $\mathrm{AE}$ & $10,243.2$ & $\begin{array}{l}\text { Detailed study/ } \\
\text { Riverine }\end{array}$ & $\begin{array}{l}\text { Medium } \\
\text { High }\end{array}$ & 3 & 10 & 0 & 4 & 0 & 0 & 0 & 15 & 6 & 35 \\
\hline Northumberland & 330036\# & $\begin{array}{l}\text { \{F1FCD3BB-D838-481A- } \\
\text { AD11-170459DFECA4\} }\end{array}$ & $\begin{array}{l}\text { Connecticut River } \\
(1012693.76,777739.63)\end{array}$ & $5 / 4 / 1989$ & $\mathrm{AE}$ & $12,355.2$ & Redelineation & $\begin{array}{l}\text { Medium } \\
\text { High }\end{array}$ & 4 & 10 & 0 & 6 & 0 & 0 & 0 & 15 & 4 & 35 \\
\hline Northumberland & 330036\# & $\begin{array}{l}\text { \{0D9CCE33-DAC6-43BE- } \\
\text { B805-7B26BF9B9C3C }\}\end{array}$ & $\begin{array}{l}\text { Roaring Brook } \\
(1027765.32,763135.31)\end{array}$ & $5 / 4 / 1989$ & $\mathrm{AE}$ & $3,484.8$ & $\begin{array}{l}\text { Detailed study/ } \\
\text { Riverine }\end{array}$ & $\begin{array}{l}\text { Medium } \\
\text { High }\end{array}$ & 6 & 10 & 0 & 6 & 0 & 0 & 0 & 15 & 4 & 35 \\
\hline Stark & 330038B & $\begin{array}{l}\{74 \text { F8DA2E-0CCB-4B71- } \\
\text { B04C-DED16D5B6915 }\end{array}$ & $\begin{array}{l}\text { Phillips Brook } \\
(1071988.44,772820.91)\end{array}$ & $4 / 2 / 1986$ & A & $4,804.8$ & $\begin{array}{l}\text { Detailed study/ } \\
\text { Riverine }\end{array}$ & $\begin{array}{l}\text { Medium } \\
\text { High }\end{array}$ & 3 & 8 & 0 & 6 & 0 & 0 & 0 & 15 & 6 & 35 \\
\hline Stewartstown & 330194A & $\begin{array}{l}\{15 \mathrm{~B} 35503-F 78 \mathrm{~B}-4683- \\
\text { 8E9A-D8EBBFC234A5 }\}\end{array}$ & $\begin{array}{l}\text { Bishop Brook } \\
(1031192.58,910902.28)\end{array}$ & $1 / 10 / 1975$ & A & $1,214.4$ & $\begin{array}{l}\text { Limited } \\
\text { Detailed study }\end{array}$ & $\begin{array}{l}\text { Medium } \\
\text { High }\end{array}$ & 5 & 10 & 0 & 1 & 0 & 5 & 0 & 15 & 4 & 35 \\
\hline Dummer & 330201 & $\begin{array}{l}\{7708383 \mathrm{C}-504 \mathrm{~A}-4 \mathrm{E} 07- \\
\text { 8B17-A9ED080F5FC8 }\end{array}$ & $\begin{array}{l}\text { Canal } \\
(1097712.52,774423.19)\end{array}$ & $1 / 17 / 1975$ & -- & $4,276.8$ & $\begin{array}{l}\text { Detailed study/ } \\
\text { Riverine }\end{array}$ & $\begin{array}{l}\text { Medium } \\
\text { High }\end{array}$ & 2 & 8 & 0 & 2 & 0 & 0 & 0 & 15 & 8 & 33 \\
\hline Gorham & 330032\# & $\begin{array}{l}\{0021 F 7 C 1-F 0 E 3-431 \mathrm{E}- \\
\text { 9F47-2405E55A3940\} }\end{array}$ & $\begin{array}{l}\text { Tinker Brook } \\
(1105447.07,710846.61)\end{array}$ & $5 / 2 / 1994$ & A & $6,652.8$ & $\begin{array}{l}\text { Detailed study/ } \\
\text { Riverine }\end{array}$ & $\begin{array}{l}\text { Medium } \\
\text { High }\end{array}$ & 6 & 10 & 0 & 4 & 0 & 0 & 0 & 15 & 4 & 33 \\
\hline Shelburne & 330037A & $\begin{array}{l}\{2 \mathrm{FF} 8 \mathrm{~B} 6 \mathrm{C} 4-3211-49 \mathrm{E} 3- \\
\text { A93F-356446E993AD }\}\end{array}$ & $\begin{array}{l}\text { East Brook } \\
(1138589.43,689644.53)\end{array}$ & $4 / 2 / 1986$ & -- & $1,214.4$ & $\begin{array}{l}\text { Detailed study/ } \\
\text { Riverine }\end{array}$ & Medium & 4 & 8 & 0 & 6 & 0 & 5 & 0 & 10 & 4 & 33 \\
\hline Lancaster & 335277\# & $\begin{array}{l}\{5 \mathrm{CAB} 3496-\mathrm{FC} 88-4090- \\
\text { A371-E669064AB7A6 }\}\end{array}$ & $\begin{array}{l}\text { Otter Brook } \\
(1021282.66,724877.94)\end{array}$ & 4/1/1982 & $\mathrm{AE}$ & $1,953.6$ & Redelineation & Medium & 4 & 10 & 0 & 8 & 0 & 0 & 0 & 10 & 4 & 32 \\
\hline
\end{tabular}


Appendix D. Prioritized flooding sources in Coos County.-Continued

[CID, Community Identification; FIS, Flood Insurance Studies; LOMC, Letter of Map Change; --, no data]

\begin{tabular}{|c|c|c|c|c|c|c|c|c|c|c|c|c|c|c|c|c|c|c|}
\hline Community & CID & Reach_ID & Description & $\begin{array}{c}\text { Current } \\
\text { analysis } \\
\text { effective } \\
\text { date }\end{array}$ & $\begin{array}{l}\text { Current } \\
\text { effective } \\
\text { zone }\end{array}$ & $\begin{array}{l}\text { Study } \\
\text { reach } \\
\text { length } \\
\text { (ft) }\end{array}$ & Study type & $\begin{array}{l}\text { Com- } \\
\text { munity } \\
\text { priority } \\
\text { range }\end{array}$ & $\begin{array}{l}\text { Com- } \\
\text { munity } \\
\text { priority }\end{array}$ & $\begin{array}{c}\text { Popu- } \\
\text { lation } \\
\text { density } \\
\text { score }\end{array}$ & $\begin{array}{l}\text { Popu- } \\
\text { lation } \\
\text { growth } \\
\text { score }\end{array}$ & $\begin{array}{c}\text { Year } \\
\text { since } \\
\text { most } \\
\text { recent } \\
\text { FIS } \\
\text { score }\end{array}$ & $\begin{array}{l}\text { Signif- } \\
\text { icant } \\
\text { area } \\
\text { score }\end{array}$ & $\begin{array}{c}\text { De- } \\
\text { velop- } \\
\text { ment } \\
\text { score }\end{array}$ & $\begin{array}{l}\text { LOMC } \\
\text { score }\end{array}$ & $\begin{array}{l}\text { Com- } \\
\text { munity } \\
\text { priority } \\
\text { value }\end{array}$ & $\begin{array}{c}\text { Com- } \\
\text { munity } \\
\text { ranking } \\
\text { value }\end{array}$ & $\begin{array}{l}\text { Total } \\
\text { score }\end{array}$ \\
\hline Lancaster & 335277\# & $\begin{array}{l}\text { \{A897AA4C-1597-422B- } \\
\text { 8090-06B24BC29F61\} }\end{array}$ & $\begin{array}{l}\text { Caleb Brook } \\
(1027664.98,728759.64)\end{array}$ & 4/1/1982 & $\mathrm{AE}$ & $2,692.8$ & Redelineation & Medium & 5 & 10 & 0 & 8 & 0 & 0 & 0 & 10 & 4 & 32 \\
\hline Dummer & 330201 & $\begin{array}{l}\{59 \text { F373A5-9F1A-4602- } \\
\text { A80D-AB0BE521E7B6 }\}\end{array}$ & $\begin{array}{l}\text { Upper Ammonoosuc R } \\
(1077340.64,767087.78)\end{array}$ & 1/17/1975 & A & $4,171.2$ & $\begin{array}{l}\text { Detailed study/ } \\
\text { Riverine }\end{array}$ & $\begin{array}{l}\text { Medium } \\
\text { High }\end{array}$ & 3 & 8 & 0 & 2 & 0 & 0 & 0 & 15 & 6 & 31 \\
\hline Jefferson & $330033 \mathrm{C}$ & $\begin{array}{l}\{\text { CE025015-E422-4F20- } \\
\text { 972C-ABF15ED08A72 }\end{array}$ & $\begin{array}{l}\text { Mill Brook } \\
(1035122.77,678722.57)\end{array}$ & 4/15/1986 & A & $3,643.2$ & Redelineation & Medium & 4 & 10 & 1 & 6 & 0 & 0 & 0 & 10 & 4 & 31 \\
\hline Jefferson & $330033 \mathrm{C}$ & $\begin{array}{l}\text { \{B663CC1F-119E-49ED- } \\
\text { BC1A-1FFD6ABC3983\} }\end{array}$ & $\begin{array}{l}\text { Mill Brook } \\
(1032841.80,686519.90)\end{array}$ & 4/15/1986 & A & $1,161.6$ & $\begin{array}{l}\text { Limited } \\
\text { Detailed study }\end{array}$ & Medium & 4 & 10 & 1 & 6 & 0 & 0 & 0 & 10 & 4 & 31 \\
\hline Jefferson & $330033 \mathrm{C}$ & $\begin{array}{l}\{\text { D712C21A-4257-4E58- } \\
\text { A303-1F9D9E6C5FAB }\}\end{array}$ & $\begin{array}{l}\text { Red Brook } \\
(1039362.47,679359.53)\end{array}$ & 4/15/1986 & A & $4,118.4$ & Redelineation & Medium & 5 & 10 & 1 & 6 & 0 & 0 & 0 & 10 & 4 & 31 \\
\hline Stewartstown & $330194 \mathrm{~A}$ & $\begin{array}{l}\text { \{9F43594F-48DD-4247- } \\
\text { A8DB-EDF8583D41D3\} }\end{array}$ & $\begin{array}{l}\text { Back Pond Brook } \\
(1023914.39,904550.81)\end{array}$ & $1 / 10 / 1975$ & A & $1,214.4$ & $\begin{array}{l}\text { Detailed study/ } \\
\text { Riverine }\end{array}$ & $\begin{array}{l}\text { Medium } \\
\text { High }\end{array}$ & 4 & 10 & 0 & 1 & 0 & 0 & 0 & 15 & 4 & 30 \\
\hline Stratford & 330039\# & $\begin{array}{l}\text { \{B55DCB03-12BF-4991- } \\
\text { 8788-10F353275CDB }\}\end{array}$ & $\begin{array}{l}\text { Unnamed } \\
(1014852.74,792381.69)\end{array}$ & 4/18/1983 & A & $6,336.0$ & $\begin{array}{l}\text { Limited } \\
\text { Detailed study }\end{array}$ & Medium & 3 & 8 & 0 & 8 & 0 & 0 & 0 & 10 & 4 & 30 \\
\hline Stratford & 330039\# & $\begin{array}{l}\{\text { AABACF3D-AF78-4F31- } \\
\text { 8ADA-9DD86D5CE316\} }\end{array}$ & $\begin{array}{l}\text { Unnamed } \\
(1012113.65,793863.41)\end{array}$ & 4/18/1983 & A & $3,062.4$ & $\begin{array}{l}\text { Limited } \\
\text { Detailed study }\end{array}$ & Medium & 4 & 8 & 0 & 8 & 0 & 0 & 0 & 10 & 4 & 30 \\
\hline Gorham & 330032\# & $\begin{array}{l}\{0 \mathrm{~B} 51 \mathrm{BC} 47-9 \mathrm{E} 2 \mathrm{C}-44 \mathrm{C} 6- \\
93 \mathrm{CD}-\mathrm{B} 1 \mathrm{BF} 0008 \mathrm{C} 2 \mathrm{CA}\}\end{array}$ & $\begin{array}{l}\text { Unnamed } \\
(1107543.38,703531.33)\end{array}$ & $5 / 2 / 1994$ & A & $1,636.8$ & Redelineation & Medium & 7 & 10 & 0 & 4 & 0 & 0 & 0 & 10 & 4 & 28 \\
\hline Stark & 330038B & $\begin{array}{l}\text { \{BFFA40EC-3F52-4847- } \\
\text { 902D-8BE1854C7536\} }\end{array}$ & $\begin{array}{l}\text { Upper Ammonoosuc R } \\
(1068814.27,770349.63)\end{array}$ & 4/2/1986 & A & $2,640.0$ & $\begin{array}{l}\text { Detailed study/ } \\
\text { Riverine }\end{array}$ & Medium & 4 & 8 & 0 & 6 & 0 & 0 & 0 & 10 & 4 & 28 \\
\hline Berlin & 330029\# & $\begin{array}{l}\text { \{198FB8D1-840C-45F5- } \\
\text { 8701-F1E67718C7D7\} }\end{array}$ & $\begin{array}{l}\text { Head Pond } \\
(1098631.85,736673.66)\end{array}$ & 6/15/1982 & A & $3,484.8$ & Redelineation & $\begin{array}{l}\text { Medium } \\
\text { Low }\end{array}$ & 4 & 10 & 0 & 8 & 0 & 0 & 0 & 5 & 4 & 27 \\
\hline Stratford & 330039\# & $\begin{array}{l}\{\text { FCCDD511-B535-45F2- } \\
\text { A971-5D46F26C25BC }\}\end{array}$ & $\begin{array}{l}\text { Nash Stream } \\
(1044025.11,805018.36)\end{array}$ & 4/18/1983 & A & $26,716.8$ & $\begin{array}{l}\text { Detailed study/ } \\
\text { Riverine }\end{array}$ & $\begin{array}{l}\text { Medium } \\
\text { Low }\end{array}$ & 5 & 8 & 0 & 8 & 0 & 0 & 0 & 5 & 4 & 25 \\
\hline Dummer & 330201 & $\begin{array}{l}\text { \{725D06C8-890B-4FC3- } \\
\text { 89B5-1162A9AF8437\} }\end{array}$ & $\begin{array}{l}\text { Androscoggin River } \\
(1110239.74,789623.82)\end{array}$ & 1/17/1975 & A & $26,241.6$ & $\begin{array}{l}\text { Detailed study/ } \\
\text { Riverine }\end{array}$ & Medium & 4 & 8 & 0 & 2 & 0 & 0 & 0 & 10 & 4 & 24 \\
\hline Dummer & 330201 & $\begin{array}{l}\text { \{7E50EF1C-AF5A-40B9- } \\
\text { B3C4-51BA99850C4C }\}\end{array}$ & $\begin{array}{l}\text { Phillips Brook } \\
(1077379.02,784684.02)\end{array}$ & 1/17/1975 & -- & $5,860.8$ & $\begin{array}{l}\text { Detailed study/ } \\
\text { Riverine }\end{array}$ & Medium & 5 & 8 & 0 & 2 & 0 & 0 & 0 & 10 & 4 & 24 \\
\hline Colebrook & 330031\# & $\begin{array}{l}\{3 \mathrm{~B} 205 \mathrm{~B} 51-6364-4 \mathrm{D} 39- \\
\text { 86D1-97DB2F2452F1\} }\end{array}$ & $\begin{array}{l}\text { Connecticut River } \\
(1024668.57,871477.79)\end{array}$ & 5/17/1989 & $\mathrm{AE}$ & $2,376.0$ & Redelineation & Medium & 4 & 10 & 0 & 6 & 0 & 0 & 0 & 0 & 4 & 20 \\
\hline
\end{tabular}


